\title{
Mouse Models of Polyglutamine Diseases in Therapeutic Approaches: Review and Data Table. Part II
}

\author{
Pawel M. Switonski • Wojciech J. Szlachcic • \\ Agnieszka Gabka • Wlodzimierz J. Krzyzosiak • \\ Maciej Figiel
}

Received: 22 April 2012 / Accepted: 29 July 2012 /Published online: 4 September 2012

(C) The Author(s) 2012. This article is published with open access at Springerlink.com

\begin{abstract}
Mouse models of human diseases are created both to understand the pathogenesis of the disorders and to find successful therapies for them. This work is the second part in a series of reviews of mouse models of polyglutamine (polyQ) hereditary disorders and focuses on in vivo experimental therapeutic approaches. Like part I of the polyQ mouse model review, this work is supplemented with a table that contains data from experimental studies of therapeutic approaches in polyQ mouse models. The aim of this review was to characterize the benefits and outcomes of various therapeutic strategies in mouse models. We examine whether the therapeutic strategies are specific to a single disease or are applicable to more than one polyQ disorder in mouse models. In addition, we discuss the suitability of mouse models in therapeutic approaches. Although the majority of therapeutic studies were performed in mouse models of Huntington disease, similar strategies were also used in other disease models.
\end{abstract}

Keywords Polyglutamine - Mouse models · Therapy · Huntington disease $\cdot$ Spinocerebellar ataxia $\cdot$ DRPLA $\cdot$ SBMA

\section{Introduction}

Polyglutamine (polyQ) diseases are dominantly inherited disorders caused by mutations in single genes, called

Electronic supplementary material The online version of this article (doi:10.1007/s12035-012-8316-3) contains supplementary material, which is available to authorized users.

P. M. Switonski • W. J. Szlachcic · A. Gabka • W. J. Krzyzosiak •

M. Figiel $(\bowtie)$

Institute of Bioorganic Chemistry, Polish Academy of Sciences,

Noskowskiego 12/14,

61-704 Poznan, Poland

e-mail: mfigiel@ibch.poznan.pl expansions, that result in the excessive elongation of $\mathrm{CAG}$ triplet tracts encoding glutamines. This type of mutation usually produces many symptoms that are primarily, but not exclusively, neurological. Currently, nine polyQ diseases have been identified, including Huntington disease (HD); spinocerebellar ataxia (SCA) types 1, 2, 3, 6, 7 and 17; dentatorubral-pallidoluysian atrophy (DRPLA); and spinal and bulbar muscular atrophy (SBMA). Although the genes where the mutation tracts are located do not belong to common gene families, the pathogenic features caused by the mutations are similar. The symptoms of these disorders include motor impairments such as dystonia and chorea in HD, ataxia in SCAs and general muscle weakness in SBMA, which often confine the patients to a wheelchair. In some cases, serious cognitive deficiencies appear at later stages of the disease $[1,2]$. The most powerful tools for studying polyQ diseases are transgenic mouse models. These models are created to explore two aspects: the disease process and potential therapies. In part I, we proposed a systematic list of phenotypes that will facilitate the characterization of mouse models and the disease process. The second aspect, finding new therapies, is discussed in the present review (part II) and is very important because polyQ diseases are currently incurable.

Many excellent and useful reviews have been published on the topic of preclinical therapy for HD and other polyQ diseases [3-6]. Here, we present an overview of the therapeutic strategies that have been tested in mouse models of polyQ diseases; more importantly, we provide an Excel data table (referred to as the data table and available in the Supplementary Materials) that lists data from papers devoted to the study of polyQ mouse models and therapies. In this table, we provide data about behavioral and molecular protocols that are used for testing the therapeutic potential of the substances and strategies that are employed in mouse 
models of polyQ diseases. The data table, which lists nearly 250 therapeutic approaches that were carefully selected, may also serve as a basis for assessing the predictive validity (that is, a model's suitability for preclinical therapy) of polyQ mouse models.

The present work is organized into several sections. The sections "Target: Clearance Machinery" to "Other Therapeutic Strategies" contain a review of the therapeutic strategies and active substances that have been used in preclinical therapeutic trials. The following section "PolyQ Mouse Models in Experimental Therapies" discusses the polyQ mouse models that were used in therapeutic trials and the phenotypes that were used to determine therapeutic outcomes. This structure is also reflected in the data table, which contains 15 columns (Fig. 1). The first two columns list the diseases and the mouse models of the diseases that were used for the experimental therapy. A second group of columns describes the phenotypes tested, states the methods used to test the phenotypes, lists the parameters that were quantified and presents the outcome of the therapy (in the column called "Treatment vs. mock"). The third set of columns contains data about the active substances used to induce the therapeutic effect, the description of the drug target and the general therapeutic strategy. Supplemental Table 1 summarizes the content of the columns in the data table.

\section{Strategies and Targets of PolyQ Experimental Therapy Approaches in Mouse Models}

The pathologically elongated polyglutamine domain has a tendency to misfold and aggregate into larger structures that eventually precipitate from cytoplasmic and nucleoplasmic solutions as insoluble inclusions; however, it is still unclear whether monomers, soluble oligomers or insoluble inclusions make the greatest contribution to the overall cytotoxicity of polyglutamine repeats. Mutated polyglutamine domains interact with other cellular components and, as a result, perturb cellular homeostasis. This disruption leads to a variety of cellular dysfunctions, including transcriptional deregulation, mitochondrial dysfunction, clearance machinery impairment, increased susceptibility to excitotoxicity, inflammation and oxidative damage, and apoptosis induction $[7,8]$. The polyglutamine domain alters several cellular processes, indicating that there are many potential targets for both pharmacological and non-pharmacological interventions. The validity and the potency of targeting various cellular pathways to alleviate disease phenotypes were assessed in mouse models of polyglutamine diseases using nearly 250 different therapeutic approaches that can be grouped into several different therapeutic strategies (Fig. 2, the data table, Supplementary Tables 1-8).

\section{Target: Clearance Machinery}

\section{Ubiquitin-Proteasome System and Autophagy}

Highly controlled and selective degradation of cellular compounds, essential for cell physiology, is executed by the ubiquitin-proteasome system (UPS) and by autophagy [9] The UPS is a multistep pathway in which redundant or damaged proteins are tagged with ubiquitin and subsequently destroyed in the proteasome complex. In contrast, the autophagic system can eliminate both single molecules, and larger structures, such as organelles, by a process of controlled enzymatic hydrolysis of cellular compounds in the lysosome [9]. Because both autophagy and the UPS maintain protein quality by removing misfolded proteins, the accumulation of large amounts of protein containing elongated polyglutamine tracts can put stress on both
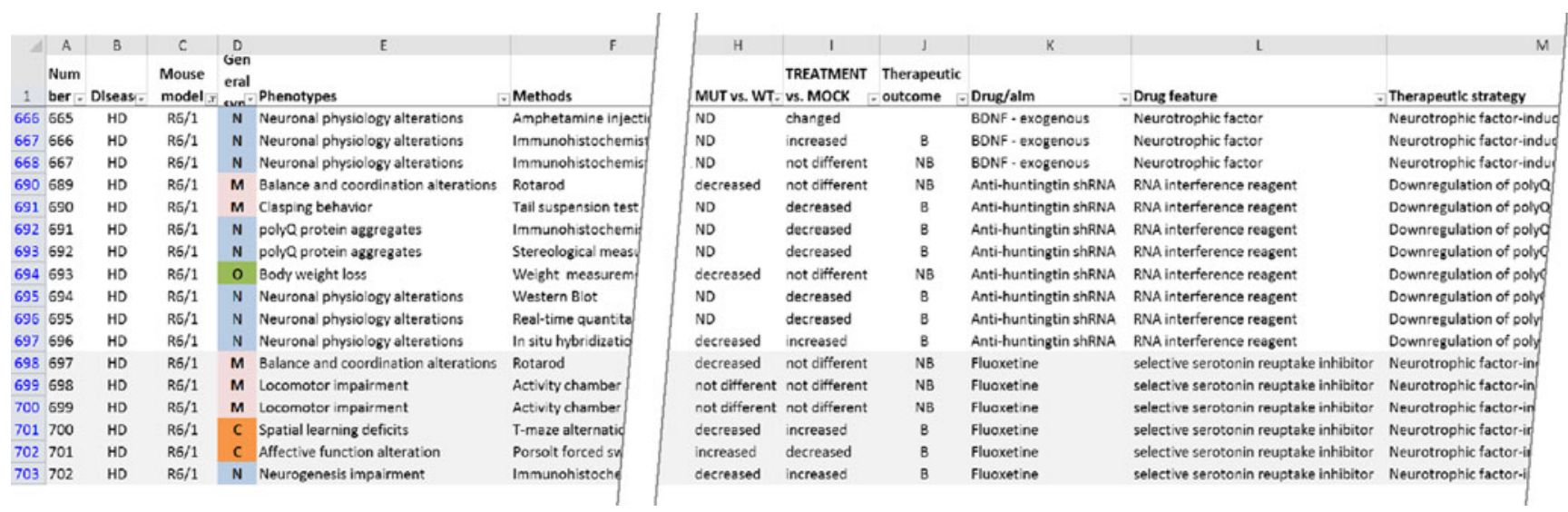

Fig. 1 The data table is an electronic resource that provides data about the therapeutic strategies, the used behavioral and molecular protocols for testing the therapy, therapeutic substances and therapeutic outcome in mouse models. The figure demonstrates only a small fragment of the data table, and the selection of records for this figure is accidental. The full data table comprises approximately 2,000 records and 17 columns 
Neurotrophic factor-induced neuroprotection Enviromental enrichment-induced neuroprotection Mitochondrial dysfunction rescue Protection from excitotoxicity Protection from oxidative stress Restoration of transcriptional alterations Inhibition of $\mathrm{pQ}$ protein aggregation Clearance machinery enhancement Chaperone related $p Q$ protein turnover Regulation of aberrant neurotransmission

Protection from apoptosis

Combined treatment

Neurogenesis promotion/cell therapy Tgase inhibition induced neuroprotection pQ protein downregulation

Others

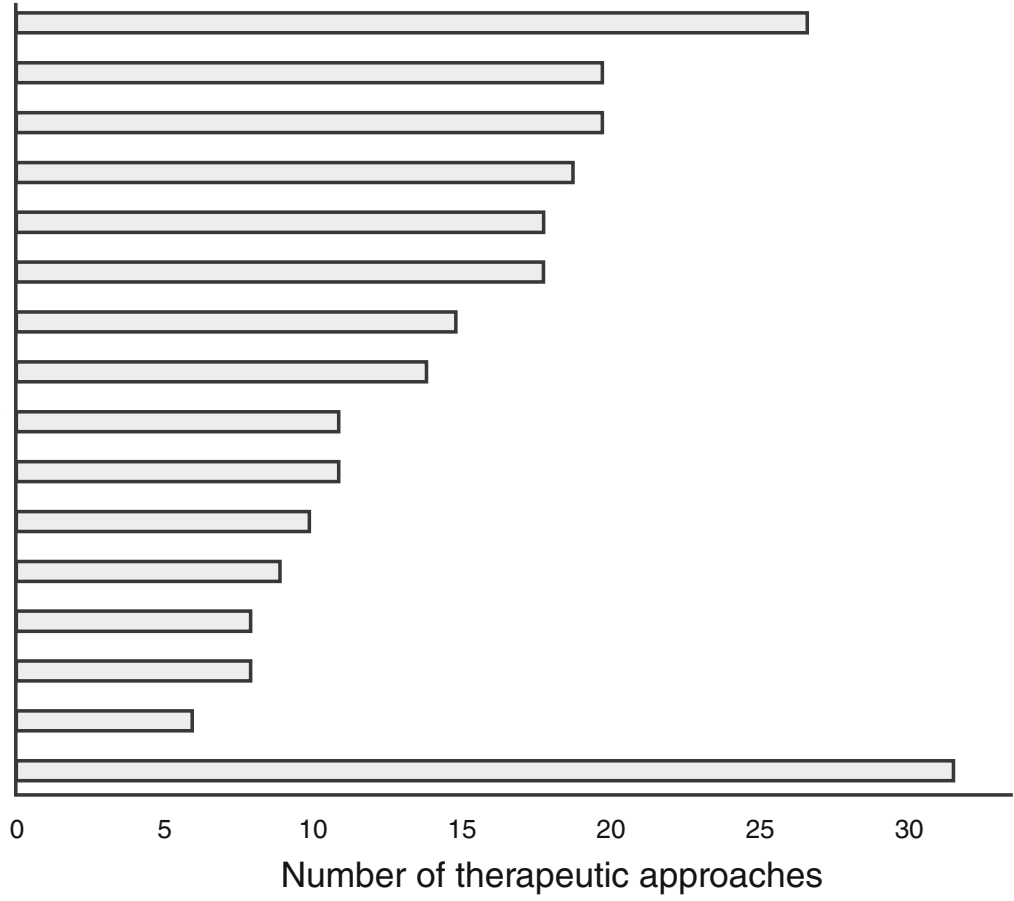

Fig. 2 The diagram shows the most studied therapeutic strategies. The therapeutic strategies are ranked by the number of therapeutic approaches that were testing a given strategy. The data table collects the total number of 250 different therapeutic approaches. The most extensively tested strategies are related to the induction of

pathways and, consequently, alter their physiological functions [10-13]. The explanations of the proposed mechanisms (e.g., proteasome blockade or overload, sequestering of important pathway components, and direct or indirect inhibition of the various pathway steps) are discussed elsewhere $[14,15]$. The therapeutic approaches aimed at boosting cellular clearance may act in a bidirectional manner by restoring the clearance machinery function that is impaired by polyQ proteins and by accelerating the degradation of polyQ proteins. Several different strategies were used to achieve these goals in mouse model studies (Fig. 3). The therapeutic effects of autophagy upregulation were tested in the HD and SCA3 models using pharmacological inhibition of the negative regulator of autophagosome formation (mammalian target of rapamycin (mTOR)) using two derivatives of rapamycin, temsirolimus, and everolimus. Interestingly, these studies yielded contradictory results. Whereas temsirolimus accelerated mutant protein removal and improved motor performance in both 70.61 SCA3 mice and N171-82Q HD mice [16, 17], everolimus did not reduce huntingtin levels in the R6/2 mouse brain and, as a result, did not induce neuroprotection despite significant brain penetration [18].

Because mTOR regulates many cellular processes in addition to autophagy, Rose and colleagues proposed an alternative approach of autophagy stimulation to avoid the side effects caused by rapamycin and its analogs. Rilmenidine, neuroprotection (with neurotrophic factors or by exposing animals to environmental stimuli), mitochondrial dysfunction, or transcriptional deregulation. Interestingly, therapeutic approaches aimed at the specific downregulation of polyQ protein expression are rarely tested in mouse models

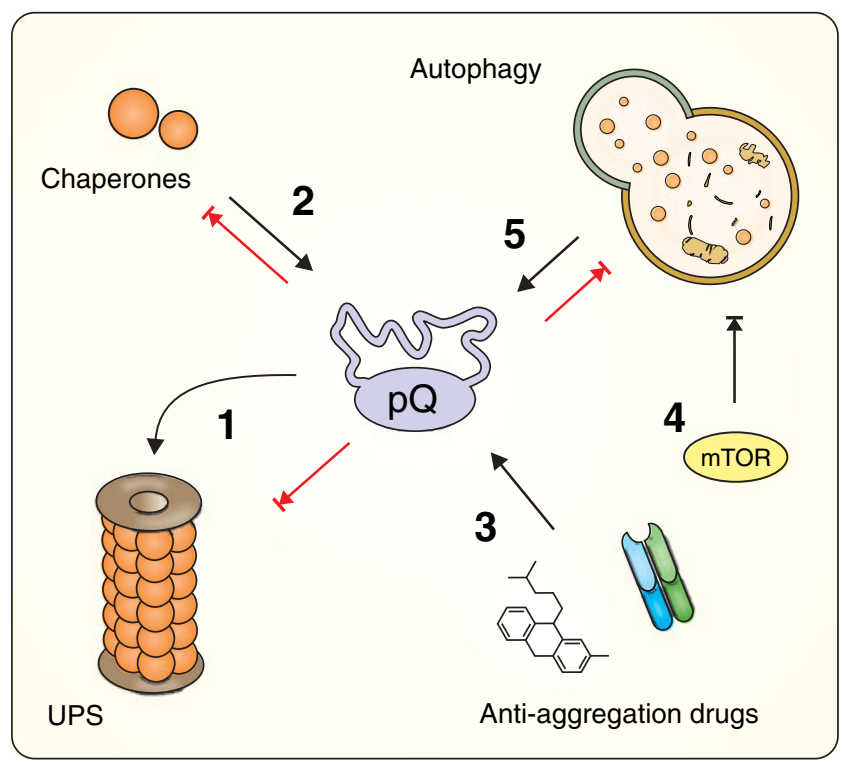

Fig. 3 Impairment of clearance machinery in polyQ diseases. Expanded polyglutamine proteins alter the physiological functions of both the UPS and the autophagic clearance pathways, thereby perturbing cellular homeostasis. Therapeutic approaches tested in polyglutamine mouse models include facilitating UPS-mediated polyQ clearance by interfering with various steps in the UPS pathway (1), increasing the levels of chaperones (2), or administrating anti-aggregation drugs (3). An increase in autophagy-mediated degradation can be achieved with mTOR inhibitors (4) and via mTOR-independent pathways (5). Ubiquitin-proteasome system (UPS), mammalian target of rapamycin (mTOR) 
an mTOR-independent autophagy inducer, reduced the level of the mutant huntingtin fragment and partially attenuated the disease phenotype in N171-82Q mice [19].

Enhanced proteasome degradation can be induced by perturbing various steps of the UPS pathway. Overexpression of the CRAG protein, which is an activator of promyelocytic leukemia protein-associated ubiquitin ligase, enhances the ubiquitination and proteasome clearance of mutant ataxin-3 and ultimately leads to improvements in both motor and neurological phenotypes in polyQ69 mice [20]. A similar strategy was implemented by Sobue's group, who crossed SBMA mice with mice overexpressing CHIP, a protein with E3 ubiquitin ligase activity. Marked amelioration of the disease phenotype was correlated with the reduction of monomeric and aggregated mutant androgen receptor (AR) proteins in the spinal cords and muscles of AR-97Q mice [21]. Finally, Wong and colleagues reported that benzyl amiloride (Ben) could be used as a candidate drug in HD treatment. Ben blocks acid-sensing ion channels in R6/2 mice, which leads to an increase in UPS activity and a decrease in huntingtin aggregation [22].

\section{Aggregation Process}

Another strategy that takes advantage of the cellular clearing system is based on changing the polyQ protein properties that are responsible for its slower degradation rate to facilitate its clearance via the UPS pathway. One question that remains unresolved is whether nuclear inclusions play a role in the pathogenesis or are actually the product of neuroprotective mechanisms to attenuate the toxic protein fragments in the cell. Notably, in some mouse models, nuclear inclusions also appear in brain regions that are unaffected in the disease process, and often the affected brain regions contain fewer inclusions than the unaffected ones (see Part I). In contrast, the brains of mice from severely affected models, such as R6/2 and N171-82Q, often contain more inclusions than those of animals with a mild pathogenesis, such as YAC128 or HD knock-ins. Finally, the formation of inclusions in conditional mouse models can be reversed when expression of polyQ protein is switched off [23], but no studies have examined whether these aggregates are responsible for the pathology and therefore whether the reversal of the formation of inclusions would be the cause of disease amelioration.

The therapeutic approaches that target aggregation processes are based on the assumption that polyglutamine toxicity can be attributed to soluble oligomers and monomers with specific conformational structure of polyQ domains rather than to insoluble inclusions [24]. Therefore, if potential therapeutic agents could prevent mutant proteins from misfolding or oligomerizing, then toxic species would not appear, and the UPS pathway would be more effective at clearing existing polyglutamine monomers. The studies examining compounds that target aggregation processes using cellular models of polyQ diseases are not discussed here because of space constraints (for a review see [25]). In mouse model studies, this strategy was implemented by using small molecules that bind to amyloids and inhibit amyloid fibril formation or by using intrabody gene therapy or chaperone activity modulation (Fig. 3).

Small Molecules and Intrabodies Small molecules that inhibit oligomerization of polyQ proteins, including chlorpromazine, minocycline, Congo red, trehalose, benzothiazoles, C2-8, and polyQ-binding peptide 1 were tested in mouse models of Huntington disease with varying success at reducing disease phenotype [26-34]. Although most of these compounds prevent inclusion formation in in vitro assays, these results have not always translated into a phenotype rescue when used in vivo to treat polyQ mice. It is possible that some compounds that inhibit inclusion body formation may prevent the soluble, toxic protein fraction from being neutralized in inclusions, inducing adverse effects of such therapeutic approach.

Intrabodies (iAbs) are engineered antibody fragments that are encoded in a vector and expressed inside cells. A number of intrabodies targeting various regions of the huntingtin protein have been developed and tested on HD mice. The mEM48-based iAb, which preferentially binds to mutant huntingtin (HTT), improves the motor performance of N171-82Q animals and reduces HTT neuropil aggregate formation; however, it is not potent enough to remove the intranuclear inclusions [35]. Patterson's laboratory has performed extensive studies in five HD models (N171-82Q, R6/2, YAC128, BACHD, and lentiviral mouse model) with two intrabodies (VL12.3 and Happ1) and has shown strong therapeutic potential of this approach. Happ1, which recognizes polyproline and polyproline-rich domains, improves motor performance, reduces neurological and cognitive abnormalities, and prolongs average lifespan. VL12.3, an intrabody recognizing the N-terminus of HTT, has beneficial effects in lentiviral model, but does not improve phenotype in YAC128, and increases mortality in R6/2 mice. Both iAbs reduce aggregate formation in cell culture and HD mouse models [36]. Recently, Snyder-Keller and colleagues reported a reduction in the aggregate phenotype in R6/1 mouse brains, even when treatment with an intrabody that recognizes the $\mathrm{N}$-terminal huntingtin region was initiated at a late stage of the disease [37]. A possible explanation of the beneficial effects of intrabodies rests in their ability to bind to the huntingtin protein, alter its conformation and therefore make the mutant huntingtin protein more accessible to the UPS system. Indeed, Wang's intrabody seems to promote the ubiquitination and clearance of mutant huntingtin fragments [35]. 
Chaperones Chaperones are proteins that assist in the proper folding of synthesized proteins, refold those proteins that are folded incorrectly and, together with other UPS components, recognize proteins with incorrect conformations that cannot be restored to their native states and designate them for degradation. The robust aggregation of polyQ proteins that occurs in cells of patients and animal models also indicates that chaperones cannot efficiently process the permanently misfolded polyQ stretches. Thus, increasing the levels of chaperone proteins is a reasonable approach to treating polyQ diseases. Despite numerous successes in inhibiting aggregate formation and rescuing cell death in non-mammalian and cell culture models (for example [38-40]), inducing the expression of various chaperones in polyQ mice, has had only modest effects in the amelioration of the polyglutamine-dependent disease phenotypes (Table 1). Overexpression of Hsp70, Hsp104, or BAG1 (an Hsp70 co-chaperone) or induction of chaperone expression by heat shock transcription factors does not reduce either motor or neurological abnormalities in N171-82Q or R6 HD animals, even though the aggregation processes are significantly hindered in these animals [41-45]. In contrast, overexpression of Hsp70 in SCA1 B05 and SBMA AR-97Q mice or pharmacologically increasing the levels of Hsp70, Hsp90, and Hsp105 in SBMA animals with orally administered geranylgeranylacetone improves both motor and neurological phenotypes [46-48]. Additionally, geldanamycin analogs 17-AAG and 17-DMAG, which bind directly to Hsp90, inhibit the formation of stable Hsp90/client protein complexes, and promote the formation of degradable proteasome-targeting complexes in the SBMA AR-97Q model. This strategy results in the clearing of mutant AR aggregates in both muscle tissue and in the spinal cord, which restores motor performance and prolongs the shortened lifespan $[49,50]$. At present, it is not clear why the chaperone strategy works in SCA1 and SBMA models and not in HD models. First, the therapeutic effects of Hsps may depend on the expression patterns and the levels of both the chaperones and the transgenic polyQ protein. Second, because chaperones form a complex network of mutual interactions and need specific partners to function properly, increasing the level of only one Hsp protein may not be sufficient to obtain enhanced polyQ turnover in different cell types. Finally, the cause may lie within the polyQ protein itself. Induced chaperone activity was ineffective in studies that were performed using the HD mouse models with artificially truncated huntingtin fragments. Such proteins may misfold and aggregate very aggressively; consequently, chaperones may not be able to overcome this effect even when they are expressed at relatively high levels. Additional studies are needed to clarify whether enhanced chaperone activity may be beneficial in treating Huntington disease, especially in the full-length HD models.

\section{Target: PolyQ Protein Expression}

Selective and permanent elimination of mutations from the genome would effectively cure polyQ patients; however, DNA editing technologies, such as homologous recombination or the use of zinc finger nucleases or TALENs, are difficult to translate to in vivo systems as therapeutic tools [51]. An alternative approach that can be considered etiological or preventive is to target the messenger RNA, thereby repressing the formation of the toxic polyQ protein. Davidson's group has used RNAi in both SCA1 and HD mice. By constructing AAV vectors that can produce siRNAs inside neurons, her group has achieved potent longterm silencing of polyQ transgenes. Injection of viral particles directly into the cerebellum and striatum of B05 and N171-82Q animals, respectively, results in a significant improvement in the disease phenotype in terms of both motor and neurological impairment $[52,53]$. Similar results were obtained in R6 models by using vectorized shRNA and naked siRNA against human huntingtin [54, 55].

Transgenic mice are good models that have allowed us to study the selective silencing of mutant genes without altering the expressions of the endogenous mouse counterparts [53-56], but naturally, such allele sets do not exist in the patient population. To study more natural conditions, RNAi reagents targeting sequences present in both transgenes and endogenes were used to achieve nonselective silencing. It was expected that partial elimination of wild-type allele expression would be a minimally harmful compromise for the effective removal of the polyQ protein. Interestingly, significant knockdown of endogenous huntingtin in the striatum of N171-82Q is well-tolerated even after 4 months despite the significant involvement of this protein in various cellular processes [57]. Similar results were also observed in lentiviral rat and mouse models of Huntington disease [58]. In addition, ataxin-3 knockout mice do not show any signs of gross pathology, indirectly indicating that the nonselective approach may be relatively safe $[59,60]$. However, prolonging the wild-type allele silencing to years or decades in patients may lead to the gradual accumulation of undesirable effects, and eventually, such a strategy could prove to be more harmful than beneficial. To overcome this potential danger, allele-specific reagents that distinguish between the mutant and normal transcripts could be used; however, their effectiveness has only been shown in cellular and lentiviral rat models. Such allele specificity may be obtained using reagents that target SNP sites [61-63] or act through miRNA-like mechanisms that can distinguish between alleles by targeting the different lengths of the CAG repeat region in the normal and mutant transcripts [64-66].

The therapeutic strategy of targeting polyQ mRNA with RNA interference decreases the expression of mutant protein and transcripts containing elongated CAG tracts. 
Table 1 Chaperone-related therapeutic approaches in mouse models of polyQ diseases

\begin{tabular}{|c|c|c|c|c|c|}
\hline Drug & Route/dose & Model & & Therapeutic outcomes & Reference \\
\hline 17-AAG & $\begin{array}{l}\text { Intraperitoneal } \\
\quad(7.5 \text { or } 75 \\
\mathrm{mg} / \mathrm{kg} / \text { week })\end{array}$ & AR-97Q (SBMA) & $\checkmark$ & $\begin{array}{l}\text { Improved motor phenotype (rotarod, } \\
\text { cage activity, gait pattern); alleviated } \\
\text { aggregate formation and nuclear } \\
\text { localization of mutant AR; reduced } \\
\text { muscle atrophy; decreased body } \\
\text { weight loss rate; prolonged life span }\end{array}$ & $\begin{array}{l}\text { Waza et al. } \\
2005 \text { [49] }\end{array}$ \\
\hline 17-DMAG & $\begin{array}{l}\text { Oral (3 or } \\
\quad 30 \mathrm{mg} / \mathrm{kg} / \text { week })\end{array}$ & AR-97Q (SBMA) & $\checkmark$ & $\begin{array}{l}\text { Improved motor phenotype (rotarod, } \\
\text { cage activity, gait pattern); alleviated } \\
\text { aggregate formation and nuclear } \\
\text { localization of mutant AR; reduced } \\
\text { muscle atrophy; decreased body weight } \\
\text { loss rate; prolonged life span }\end{array}$ & $\begin{array}{l}\text { Tokui et al. } \\
2009[50]\end{array}$ \\
\hline BAG1 & Overexpression & N171-82Q (HD) & $\begin{array}{l}\checkmark \\
\times\end{array}$ & $\begin{array}{l}\text { Improved rotarod phenotype (only in males) } \\
\text { No change in aggregate formation, body } \\
\text { weight loss rate, life span, and clasping } \\
\text { phenotype }\end{array}$ & $\begin{array}{l}\text { Orr et al. } \\
2008[43]\end{array}$ \\
\hline GGA & $\begin{array}{l}\text { Oral }(\sim 600 \text { and } \\
1,200 \mathrm{mg} / \mathrm{kg} / \text { day })\end{array}$ & AR-97Q (SBMA) & $\checkmark$ & $\begin{array}{l}\text { Improved motor phenotype (rotarod, } \\
\text { cage activity, gait pattern); alleviated } \\
\text { aggregate formation and nuclear localization } \\
\text { of mutant AR; reduced muscle atrophy; } \\
\text { decreased body weight loss rate; prolonged } \\
\text { life span }\end{array}$ & $\begin{array}{c}\text { Katsuno et al. } \\
2005 \text { [48] }\end{array}$ \\
\hline HSF1 & Overexpression & R6/2 (HD) & $\checkmark$ & $\begin{array}{l}\text { Reduced muscular atrophy and muscular } \\
\text { inclusions; prolonged life span } \\
\text { No change in clasping phenotype and body } \\
\text { weight loss rate; no reduction in brain } \\
\text { atrophy and neuronal inclusion formation }\end{array}$ & $\begin{array}{l}\text { Fujimoto et al. } \\
2005[45]\end{array}$ \\
\hline hsp104 & Overexpression & N171-82Q (HD) & $\checkmark$ & $\begin{array}{l}\text { Reduced number of cortical aggregates; } \\
\text { prolonged life span } \\
\text { No change in rotarod and grip strength } \\
\text { performance; no change in body weight } \\
\text { loss rate }\end{array}$ & $\begin{array}{c}\text { Vacher et al. } \\
2005 \text { [42] }\end{array}$ \\
\hline Hsp70 & $\begin{array}{l}\text { Overexpression } \\
\text { (5- to } 10 \text {-fold of } \\
\text { endogenous level) }\end{array}$ & AR-97Q (SBMA) & $\checkmark$ & $\begin{array}{l}\text { Improved motor phenotype (rotarod, } \\
\text { cage activity, gait pattern); alleviated } \\
\text { aggregate formation and nuclear } \\
\text { localization of mutant AR; decreased } \\
\text { body weight loss rate; prolonged life span }\end{array}$ & $\begin{array}{c}\text { Adachi et al. } \\
2003 \text { [47] }\end{array}$ \\
\hline Hsp70 & $\begin{array}{l}\text { Overexpression } \\
(\sim 10 \text { - to } 20 \text {-fold } \\
\text { of endogenous level })\end{array}$ & B05 (SCA1) & $\checkmark$ & $\begin{array}{l}\text { Improved rotarod phenotype; improved } \\
\text { Purkinje cell morphology } \\
\text { No change in NII formation }\end{array}$ & $\begin{array}{l}\text { Cummings et al. } \\
2001[46]\end{array}$ \\
\hline Hsp70 & $\begin{array}{l}\text { Overexpression } \\
\text { (5- to } 15 \text {-fold of } \\
\text { endogenous level) }\end{array}$ & R6/2 (HD) & $\begin{array}{l}\checkmark \\
\times\end{array}$ & $\begin{array}{l}\text { Decreased body weight loss rate } \\
\text { No change in clasping behavior; no } \\
\text { reduction in brain atrophy and neuronal } \\
\text { abnormal morphology; no change in NII } \\
\text { formation and life span }\end{array}$ & $\begin{array}{l}\text { Hansson et al. } \\
2003 \text { [41] }\end{array}$ \\
\hline Hsp70 & Overexpression & R6/2 (HD) & $\checkmark$ & $\begin{array}{l}\text { Delayed aggregate formation in } \\
\text { hippocampal slice culture } \\
\text { No change in rotarod and grip strength } \\
\text { performance; increased body weight } \\
\text { loss rate }\end{array}$ & $\begin{array}{l}\text { Hay et al. } \\
2004[44]\end{array}$ \\
\hline HSP70/HDJ2 & $\begin{array}{l}\text { Overexpression } \\
\text { (5- to } 10 \text {-fold of } \\
\text { endogenous level) }\end{array}$ & 90Q R7E (SCA7) & $x$ & $\begin{array}{l}\text { No change in rod photoreceptor functions, } \\
\text { no morphological changes of retinal layers, } \\
\text { and no change in NII formation }\end{array}$ & $\begin{array}{l}\text { Helmlinger et al. } \\
2004 \text { [392] }\end{array}$ \\
\hline HSJ1a & Overexpression & R6/2 (HD) & $\checkmark$ & $\begin{array}{l}\text { Reduced nuclear aggregate load; increased } \\
\text { levels of soluble huntingtin; improved } \\
\text { rotarod performance and forelimb grip } \\
\text { strength; improved exploratory activity; } \\
\text { increased BDNF level } \\
\text { No change in body and brain weight loss rate }\end{array}$ & $\begin{array}{l}\text { Labbadia et al. } \\
2012 \text { [393] }\end{array}$ \\
\hline
\end{tabular}


Silencing of both components in the cell may provide additional therapeutic benefits because recently, RNA gain-offunction by transcripts harboring expanded CAG repeats has been increasingly recognized as a pathogenic factor in polyQ diseases $[67,68]$.

\section{Target: Degenerating Neurons-Neuroprotection/}

\section{Neuromodulation}

The most striking aspect of polyglutamine diseases is the progressive morphological and physiological degeneration, followed by the death of specific neuronal subpopulations. Several experimental therapeutic strategies have been designed to prevent neuronal death by strengthening the overall health of neurons and promoting their survival despite the neurotoxicity of the mutant polyQ protein (Fig. 4).

\section{Neurotrophic Factors}

Neurotrophic factors are naturally occurring signaling proteins that are essential for nervous system development and promote neuronal growth, differentiation, and the formation of neuronal connections [69]. They also play important roles in the adult brain and peripheral nervous

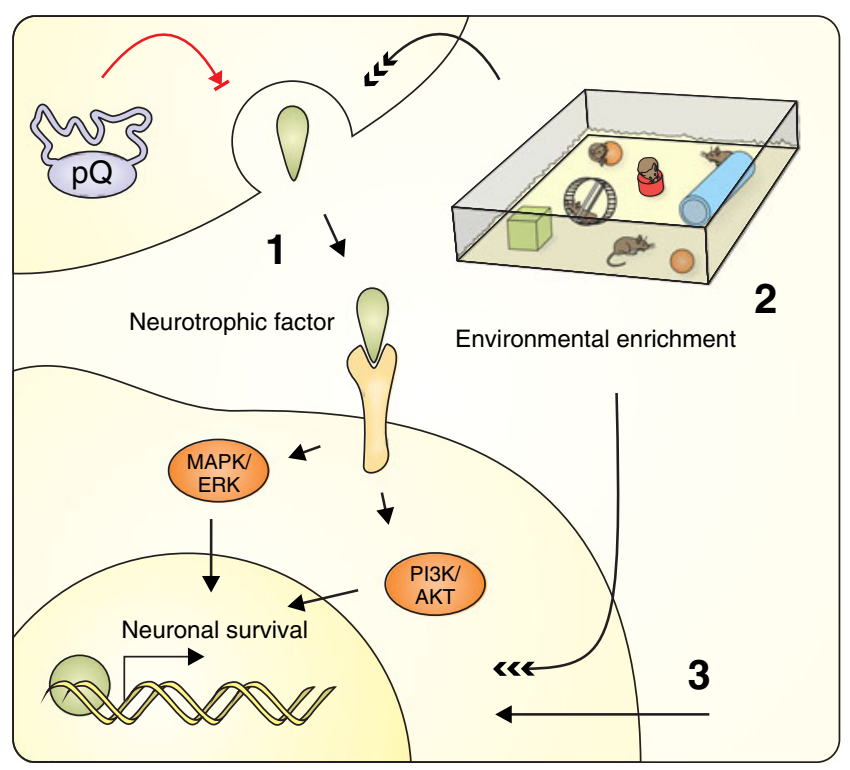

Fig. 4 Neuroprotective and neuromodulatory strategies targeting the degenerating neurons in polyQ diseases. These experimental therapeutic strategies prevent neuronal death by supporting overall health and promoting survival. The therapy can be implemented in the following ways: by administering or inducing the expression of neurotrophic factors that promote neuronal survival (1); by exposing the animals to an enriched environment that results in the upregulation of endogenous neurotrophic factors and genes involved in synaptic plasticity, growth, and neurogenesis (2); or by other neuromodulation-related therapeutic strategies (e.g., the regulation of neurotransmitter activity) that also lead to the induction of neuroprotection (3). See the text for a detailed description system, where they are responsible for maintaining proper neuronal phenotypes and functions and supporting neuronal survival [70, 71]. Additionally, neurotrophic factors are involved in neuronal protection and regeneration in several neurodegenerative diseases and following neurotraumatic injuries [72-75]. The neuroprotective properties of neurotrophic factors make them attractive candidates for preventing the damage caused by mutant polyQ proteins (Table 2).

$B D N F$ The brain-derived neurotrophic factor (BDNF) has emerged as the most promising therapeutic neurotrophic factor because it is important in both developing and adult neurons and its expression is deregulated in HD patients and animal models [76, 77]. Normally, BDNF is produced in cortical neurons and is anterogradely transported to the striatum. Mutant huntingtin alters this physiological condition in two ways. First, polyQ mutations affect the normal function of wild-type HTT, which is part of the motor protein complex and promotes vesicular transport along microtubules, subsequently leading to decreased BDNF transportation [78]. Second, mutant huntingtin, through aberrant interactions with transcription factors, can affect the regulation of BDNF promoters, inducing its striatal deficits [79]. Alberch's group used R6/1 mice with a partial depletion of endogenous BDNF to demonstrate that this protein is involved in the regulation of both the age of onset and the severity of motor and neuronal dysfunctions in vivo [80-82]. Moreover, intrastriatal injection of BDNF in R6/1 animals is sufficient to restore the enkephalin level in striatal projection neurons; this population of neurons is one of the most affected populations in HD [80]. The beneficial effects of increases in BDNF level were observed by other groups and confirmed the results from studies of toxin-induced HD rats that had originally demonstrated the neuroprotective effect of neurotrophins [83-85]. Gharami and colleagues and Xie and colleagues increased BDNF levels by crossing R6/1 and YAC128 animals, respectively, with mice that were overexpressing BDNF under the control of the promoter for the alpha subunit of $\mathrm{Ca}^{2+} /$ calmodulin-dependent protein kinase II. This strategy resulted in increased levels of BDNF and TrkB signaling activity in the cerebral cortex and striatum, which ameliorated motor dysfunction and rescued brain weight loss [86, 87]. Cho and colleagues used adenoviral vectors to deliver BDNF- and Noggin-encoding constructs to the ependymal cells of R6/2 animals. They observed recruitment of neuronal cells to the adult striatum from subependymal progenitors and the subsequent development of recruited neuronal cells into DARPP-32+ and GABAergic medium spiny neurons. Moreover, treated mice showed improvements in motor performance and lived longer than mock-treated and untreated controls [88]. 
Table 2 Neurotrophic factor-related therapeutic approaches in mouse models of polyQ diseases

\begin{tabular}{|c|c|c|c|c|c|}
\hline Drug & Route/dose & Model & & Therapeutic outcomes & Reference \\
\hline BDNF & $\begin{array}{l}\text { Osmotic pump } \\
(4.5 \mu \mathrm{g} / \text { day })\end{array}$ & R6/1 (HD) & $\begin{array}{l}\checkmark \\
\times\end{array}$ & $\begin{array}{l}\text { Enhanced number of encephalin }+ \text { neurons } \\
\text { No change in number of substance } \mathrm{P}+\text { neurons }\end{array}$ & $\begin{array}{l}\text { Canals et al. } \\
2004[80]\end{array}$ \\
\hline BDNF & $\begin{array}{l}\text { Overexpression ( } 3 \text { - fold } \\
\text { of endogenous level) }\end{array}$ & R6/1 (HD) & $\checkmark$ & $\begin{array}{l}\text { Improved rotarod phenotype; decreased } \\
\text { body weight loss rate (females); increased } \\
\text { brain weight; normalized cortical and striatal } \\
\text { volumes; reduced aggregates formation } \\
\text { No change in ventricle size }\end{array}$ & $\begin{array}{l}\text { Gharami et al. } \\
2008[86]\end{array}$ \\
\hline BDNF & $\begin{array}{l}\text { Intrastriatal injection of } \\
6 \times 10^{5} \mathrm{MSC} \text { cells } \\
\text { overexpressing BDNF }\end{array}$ & YAC128 (HD) & $\checkmark$ & $\begin{array}{l}\text { Improved rotarod and clasping behavior; } \\
\text { reduced neuronal loss within the striatum }\end{array}$ & $\begin{array}{l}\text { Dey et al. } \\
2010[91]\end{array}$ \\
\hline BDNF & $\begin{array}{l}\text { Overexpression (2-3-fold } \\
\text { of endogenous level) }\end{array}$ & YAC128 (HD) & $\times$ & $\begin{array}{l}\text { Improved gait pattern, rotarod, and beam walk } \\
\text { phenotype; reversed cognitive deficits; reduced } \\
\text { brain atrophy and loss of striatal neurons; } \\
\text { normalized spine morphology and expression } \\
\text { of the striatal dopamine receptor D } 2 \text { and enkephalin } \\
\text { No change in grip strength }\end{array}$ & $\begin{array}{l}\text { Xie et al. } \\
2010[87]\end{array}$ \\
\hline $\begin{array}{l}\text { BDNF and } \\
\text { Noggin }\end{array}$ & $\begin{array}{l}\text { Adenoviral-mediated } \\
\text { expression }\left(\sim 1.5 \times 10^{9}\right. \\
\text { vector genomes each })\end{array}$ & R6/2 (HD) & $\checkmark$ & $\begin{array}{l}\text { Improved motor phenotype (rotarod and } \\
\text { open field activity); increased neurogenesis; } \\
\text { prolonged life span }\end{array}$ & $\begin{array}{l}\text { Cho et al. } \\
2007[88]\end{array}$ \\
\hline CNTF & $\begin{array}{l}\text { AAV-mediated expression } \\
\left(2.7 \times 10^{9} \text { vector genomes }\right)\end{array}$ & R6/1 (HD) & $\checkmark$ & $\begin{array}{l}\text { Increased body weight loss rate; aggravated } \\
\text { rotarod phenotype; aggravated general } \\
\text { appearance and behavior; no change in } \\
\text { morphology and distribution of striatal } \\
\text { cells; no change in aggregate load }\end{array}$ & $\begin{array}{l}\text { Denovan-Wright } \\
\text { et al. } 2008 \text { [94] }\end{array}$ \\
\hline CNTF & $\begin{array}{l}\text { Lentiviral-mediated } \\
\text { expression }\end{array}$ & YAC72 (HD) & $\begin{array}{l}\checkmark \\
\times\end{array}$ & $\begin{array}{l}\text { Reduced hyperactivity; reduced number } \\
\text { of striatal dark cells } \\
\text { No change in clasping behavior, rotarod } \\
\text { phenotype, and brain weight loss; decreased } \\
\text { number of DARPP- } 32 \text { and neun positive } \\
\text { neurons; no change in the number of } \\
\text { NADPH-d neurons }\end{array}$ & $\begin{array}{l}\text { Zala et al. } \\
2004[93]\end{array}$ \\
\hline FGF-2 & $\begin{array}{l}\text { Subcutaneous injection } \\
(1.5 \mu \mathrm{g} / \text { week })\end{array}$ & R6/2 (HD) & $\checkmark$ & $\begin{array}{l}\text { Increased neurogenesis; improved rotarod } \\
\text { phenotype; reduced tremor; reduced aggregate } \\
\text { formation; decreased body weight loss rate; } \\
\text { prolonged life span }\end{array}$ & $\begin{array}{l}\text { Jin et al. } \\
2005[92]\end{array}$ \\
\hline GDNF & $\begin{array}{l}\text { AAV-mediated expression } \\
\left(4 \times 10^{9} \text { vector genomes }\right)\end{array}$ & N171-82Q (HD) & $\begin{array}{l}\checkmark \\
\times\end{array}$ & $\begin{array}{l}\text { Improved rotarod and clasping phenotype; } \\
\text { increased number and volume of striatal neurons } \\
\text { No change in striatal volume and number of } \\
\text { total striatal inclusion }\end{array}$ & $\begin{array}{l}\text { McBride et al. } \\
2006 \text { [89] }\end{array}$ \\
\hline GDNF & $\begin{array}{l}\text { Intrastriatal injection of } \\
3 \times 10^{5} \mathrm{mNPC} \text { cells } \\
\text { overexpressing GDNF }\end{array}$ & N171-82Q (HD) & $\begin{array}{l}\checkmark \\
\times\end{array}$ & $\begin{array}{l}\text { Improved rotarod phenotype; alleviated } \\
\text { aggregate formation; reduced neuronal loss } \\
\text { No change in cortical thickness and in number } \\
\text { of dopamine neurons; no long-term change in } \\
\text { body weight loss rate }\end{array}$ & $\begin{array}{l}\text { Ebert et al. } \\
2010[394]\end{array}$ \\
\hline GDNF & $\begin{array}{l}\text { Lentiviral-mediated } \\
\text { expression }\end{array}$ & R6/2 (HD) & $x$ & $\begin{array}{l}\text { No change in motor phenotype (rotarod, } \\
\text { clasping behavior, open field activity); no } \\
\text { change in body weight loss rate; no reduction } \\
\text { in brain atrophy, neuronal inclusion formation, } \\
\text { and cell proliferation in DG }\end{array}$ & $\begin{array}{l}\text { Popovic et al. } \\
2005[395]\end{array}$ \\
\hline Neurturin & $\begin{array}{l}\text { AAV-mediated expression } \\
\left(4 \times 10^{9} \text { vector genomes }\right)\end{array}$ & N171-82Q (HD) & $\begin{array}{l}\checkmark \\
\times\end{array}$ & $\begin{array}{l}\text { Improved motor phenotype (rotarod, clasping } \\
\text { behavior, gait pattern); reduced neuronal loss } \\
\text { No change in neuronal morphology and aggregate } \\
\text { formation; no change in shortened life span }\end{array}$ & $\begin{array}{l}\text { Ramaswamy et } \\
\text { al. } 2009 \text { [90] }\end{array}$ \\
\hline NGF & $\begin{array}{l}\text { Intrastriatal injection of } \\
6 \times 10^{5} \mathrm{MSC} \text { cells } \\
\text { overexpressing NGF }\end{array}$ & YAC128 (HD) & $\begin{array}{l}\checkmark \\
\times\end{array}$ & $\begin{array}{l}\text { Improved rotarod and clasping behavior } \\
\text { No change in neuronal loss within the striatum }\end{array}$ & $\begin{array}{l}\text { Dey et al. } \\
2010[91]\end{array}$ \\
\hline VEGF & $\begin{array}{l}\text { Overexpression or } \\
\text { intracerebroventricular } \\
\text { infusion of recombinant } \\
\text { Vegf }(2.5 \mu \mathrm{g})\end{array}$ & 154Q/2Q (SCA1) & $\checkmark$ & $\begin{array}{l}\text { Improved rotarod phenotype; increased } \\
\text { cerebellar vessel total length and density; } \\
\text { increased staining for calbindin }\end{array}$ & $\begin{array}{l}\text { Cvetanovic et } \\
\text { al. } 2011 \text { [396] }\end{array}$ \\
\hline
\end{tabular}


Other Factors Other neurotrophic factors have also been tested in HD mouse models (Table 2). Kordower's group induced the overexpression of exogenous glial cell linederived neurotrophic factor and neurturin in the N171-82Q mouse striatum by using AAV vectors. Injection of both factors resulted in neuroprotection of the injected structures against striatal cell loss, as well as a delay in motor deficit progression $[89,90]$. Dey and colleagues transplanted bone marrow mesenchymal stem cells that had been genetically engineered to overexpress nerve growth factor or BDNF into YAC128 mice. Both factors reduced clasping behavior, although BDNF also reduced neuronal loss within the striatum of YAC animals [91]. In R6/2 mice, subcutaneously administered fibroblast growth factor 2 crossed the bloodbrain barrier, increased the number of proliferating cells by $150 \%$, reduced polyglutamine aggregates, improved motor performance, and extended the lifespan [92]. Interestingly, lentiviral and AAV vectors mediating the long-term expression of ciliary neurotrophic factor have not produced beneficial effects in YAC72 and R6/1 mice, respectively. In the second case, the mice developed motor impairments at an earlier age and displayed significant decreases in the levels of striatal transcripts instead [93, 94].

Approaches that Involve Inducing the Expression of Endogenous Neurotrophic Factors Whereas viral-mediated overexpression, transplantation of engineered cells or crossing approaches are useful methods of inducing the expression of neurotrophic factors in laboratory animals; implementing this strategy in humans would require more convenient methods. One possible method would be to enhance the expression of endogenous factors by means of small molecules that are capable of crossing the blood-brain barrier. Antidepressants that belong to the selective serotonin reuptake inhibitor (SSRI) class, such as sertraline, fluoxetine and paroxetine, prolong lifespan, improve motor and neuropathological phenotypes and enhance neurogenesis in the R6 and N171-82Q mouse models of HD. These beneficial effects may be partially mediated by the ability of SSRIs to increase endogenous BDNF levels [95-99]. The positive effect of SSRI treatment may also result from serotonininduced neuroprotective pathways. Serotonin triggers signaling cascade that lead to neurite outgrowth, synaptogenesis, neurogenesis and cell survival, and BDNF can promote the development and function of serotonergic neurons [100].

BDNF upregulation was reported in several experimental HD treatment approaches, including:

- Modulation of AMPA-type glutamate receptor by ampakine CX929 [101, 102]

- Modulation of signaling pathways, such as JNK and ERK (using CEP-1347), cAMP/CREB (using phosphodiesterase inhibitors rolipram and TP-10), or the Ask1 apoptotic pathway (using an anti-Ask1 antibody) [103-106]

- Strategies aimed at reversing mitochondrial energy impairment [107-109]

- Transglutaminase activity modulation with cystamine and cysteamine treatment [110]

- Dietary restriction [111]

- Anti-excitotoxic drugs memantine and riluzole, which have been used in HD mouse treatment and have also increased BDNF levels in other studies $[112,113]$

The finding that BDNF expression and activity are controlled by a complex network that involves many regulatory activities in which polyQ HTT also participates may explain the frequent reports of BDNF upregulation in conjunction with HD therapy $[114,115]$. Therefore, using nonselective drugs or targeting signaling pathways that regulate BDNF expression may coincidently result in increased BDNF levels. Although such upregulation is generally positive from a therapeutic point of view, it may be misleading when the molecular mechanisms of the beneficial effects need to be interpreted.

\section{Environmental Enrichment}

The environmental enrichment strategy is one where the animals are kept in improved environmental conditions relative to standard laboratory housing methods and are provided with objects that promote physical, cognitive, and social development (Fig. 4). The experimental method of enrichment is complex and usually includes more than one of the following: large cages and housing in larger groups, tunnels, nesting materials, toys that are changed frequently and introduced as an element of novelty, and opportunities for physical activity (usually running wheels or treadmills) [116]. The initial reports of the beneficial effect of environmental enrichment in experimental therapy for Huntington disease appeared in 2000 and showed that exposing R6 mice to a stimulating, enriched environment from an early age reduced motor impairment and some of the neuropathological aspects of HD $[117,118]$. Subsequently, many groups tested the ability of enriched conditions, dietary enhancement, or voluntary or forced motor training to elicit phenotypic improvements, and these groups found effects that were generally positive but rather moderate [28, 119-129] (Table 3). The mechanisms that account for such a rescue of neuropathological and motor functions are not fully understood. Environmental manipulations result in the upregulation of genes involved in synaptic plasticity and growth, including neurotrophic factors and neurotransmitters, which, as a result, may lead to general improvement in the health of the nervous system due to increased neuroprotection and neurogenesis [130-132]. In R6/1 studies, Spires 
Table 3 Environmental enrichment-related therapeutic approaches in mouse models of polyQ diseases

\begin{tabular}{|c|c|c|c|c|}
\hline Approach & Model & & Therapeutic outcomes & Reference \\
\hline $\begin{array}{l}\text { Environmental enrichment } \\
\text { cages (exercise wheels, } \\
\text { hiding tubes, and social } \\
\text { interaction) }\end{array}$ & N171-82Q (HD) & $\checkmark$ & $\begin{array}{l}\text { Improved rotarod performance; attenuated } \\
\text { body weight decline } \\
\text { No change in life span }\end{array}$ & $\begin{array}{l}\text { Schilling et al. } \\
2004 \text { [28] }\end{array}$ \\
\hline $\begin{array}{l}\text { Environmental enrichment } \\
\text { cages (cardboard, paper, } \\
\text { and plastic objects) }\end{array}$ & R6/1 (HD) & $\checkmark$ & $\begin{array}{l}\text { Delayed "turning task" phenotype and } \\
\text { clasping behavior; attenuated peristriatal } \\
\text { cerebral atrophy } \\
\text { No change in body weight loss rate and no } \\
\text { significant change in striatal volume; no } \\
\text { significant difference in the overall density of inclusions }\end{array}$ & $\begin{array}{l}\text { van Dellen et al. } \\
2000[117]\end{array}$ \\
\hline $\begin{array}{l}\text { Environmental enrichment } \\
\text { cages (cardboard boxes, } \\
\text { open wooden boxes, } \\
\text { cylindrical cardboard } \\
\text { tunnels, and folded } \\
\text { sheets of paper) }\end{array}$ & R6/1 (HD) & $\checkmark$ & $\begin{array}{l}\text { Improved rotarod performance; partially } \\
\text { ameliorated body weight loss; increased } \\
\text { striatal BDNF level; increased cortical } \\
\text { DARPP-32 level } \\
\text { No improvement in brain weight loss; } \\
\text { no change in striatal DARPP-32 level }\end{array}$ & $\begin{array}{l}\text { Spires et al. } \\
2004 \text { [121] }\end{array}$ \\
\hline $\begin{array}{l}\text { Voluntary physical } \\
\text { exercise (running wheels) }\end{array}$ & R6/1 (HD) & $\checkmark$ & $\begin{array}{l}\text { Reduced abnormal rearing behavior; delayed } \\
\text { rear paw clasping behavior; rescued deficit in } \\
\text { spatial working memory; increased striatal } \\
\text { mRNA } B D N F \text { level } \\
\text { No change in rotarod performance; no } \\
\text { change in abnormal BDNF levels }\end{array}$ & $\begin{array}{l}\text { Pang et al. } \\
2006 \text { [123] }\end{array}$ \\
\hline $\begin{array}{l}\text { Environmental } \\
\text { enrichment cages } \\
\text { (plastic and cardboard objects) }\end{array}$ & R6/1 (HD) & $\checkmark$ & $\begin{array}{l}\text { Increased number of BrdU }+ \text { amd DCX }+ \\
\text { cells in dentate gyrus; increased length of } \\
\text { neuritis; increased DCX }+ \text { cells migration } \\
\text { distance from subgranular zone } \\
\text { No change in the number of BrdU }+ \text { cells } \\
\text { in subventricular zone; no change in rotarod performance }\end{array}$ & $\begin{array}{l}\text { Lazic et al. } \\
2006[122]\end{array}$ \\
\hline $\begin{array}{l}\text { Environmental enrichment } \\
\text { cages (cardboard boxes, } \\
\text { plastic conical tubes, } \\
\text { cylindrical cardboard } \\
\text { tunnels, and folded } \\
\text { sheets of paper) }\end{array}$ & R6/1 (HD) & $\checkmark$ & $\begin{array}{l}\text { Improved performance on accelerating rotarod } \\
\text { rescued abnormal habituation of locomotor } \\
\text { activity and exploratory behavior } \\
\text { No change in body and brain weight loss; } \\
\text { no reduction in shrinkage of the striatum } \\
\text { and anterior cingulate cortex; no change } \\
\text { in density of protein aggregates }\end{array}$ & $\begin{array}{l}\text { van Dellen et al. } \\
2008 \text { [125] }\end{array}$ \\
\hline $\begin{array}{l}\text { Voluntary physical } \\
\text { exercise (running wheels) }\end{array}$ & R6/1 (HD) & $\checkmark$ & $\begin{array}{l}\text { Delayed horizontal rod phenotype and } \\
\text { clasping phenotype; rescued abnormal } \\
\text { habituation of locomotor activity and } \\
\text { exploratory behavior } \\
\text { No change in performance on accelerating } \\
\text { rotarod; no change in body and brain weight } \\
\text { loss; no reduction in shrinkage of the striatum } \\
\text { and anterior cingulate cortex; no change in } \\
\text { density of protein aggregates }\end{array}$ & $\begin{array}{l}\text { van Dellen et al. } \\
2008 \text { [125] }\end{array}$ \\
\hline $\begin{array}{l}\text { Environmental } \\
\text { enrichment cages } \\
\text { (objects varying in } \\
\text { shape, texture and } \\
\text { size); more frequent } \\
\text { animal handling }\end{array}$ & R6/1 (HD) & $\checkmark$ & $\begin{array}{l}\text { Ameliorated deficit in spatial learning on } \\
\text { the Barnes maze; increased cortical and } \\
\text { hippocampal synaptophysin levels; } \\
\text { increased hippocampal PSD-95 level }\end{array}$ & $\begin{array}{l}\text { Nithianantharajah } \\
\text { et al. } 2008 \text { [124] }\end{array}$ \\
\hline $\begin{array}{l}\text { Environmental } \\
\text { enrichment cages } \\
\text { (novel objects) }\end{array}$ & R6/1 (HD) & $\begin{array}{l}\checkmark \\
\times\end{array}$ & $\begin{array}{l}\text { Reduced accumulation and size of NII } \\
\text { No change in dopamine and adenosine } \\
\text { receptor binding levels; no significant } \\
\text { environmental enrichment-related changes } \\
\text { detectable by microarray; no difference } \\
\text { in the level of transgene mRNA expression }\end{array}$ & $\begin{array}{l}\text { Benn et al. } \\
2010 \text { [126] }\end{array}$ \\
\hline $\begin{array}{l}\text { Environmental } \\
\text { enrichment cages } \\
\text { (cardboard rolls, } \\
\text { wire, mesh, shredded }\end{array}$ & R6/1 (HD) & $\begin{array}{l}\checkmark \\
\times\end{array}$ & $\begin{array}{l}\text { Altered methylation pattern at specific } \\
\text { sites within CpG islands } \\
\text { No change in hippocampal BDNF mRNA } \\
\text { level in R6/1 mice }\end{array}$ & $\begin{array}{l}\text { Zajac et al. } \\
2010 \text { [128] }\end{array}$ \\
\hline
\end{tabular}


Table 3 (continued)

\begin{tabular}{|c|c|c|c|c|}
\hline Approach & Model & & Therapeutic outcomes & Reference \\
\hline \multicolumn{5}{|l|}{$\begin{array}{l}\text { paper, wooden, and } \\
\text { plastic objects) }\end{array}$} \\
\hline $\begin{array}{l}\text { Voluntary physical } \\
\text { exercise (running wheels) }\end{array}$ & R6/1 (HD) & $\checkmark$ & $\begin{array}{l}\text { Increased hippocampal } B D N F \text { mRNA levels } \\
\text { (females only); altered methylation pattern } \\
\text { at specific sites within CpG islands }\end{array}$ & $\begin{array}{l}\text { Zajac et al. } \\
\quad 2010[128]\end{array}$ \\
\hline $\begin{array}{l}\text { Enhanced diet }+ \text { mixed } \\
\text { housing of TG mice } \\
\text { with WT mice }\end{array}$ & R6/2 (HD) & $\checkmark$ & $\begin{array}{l}\text { Decreased body weight loss rate; increased } \\
\text { in the survival of the first } 50 \% \text { of mice to die }\end{array}$ & $\begin{array}{l}\text { Carter et al. } \\
2000[118]\end{array}$ \\
\hline $\begin{array}{l}\text { Enhanced diet+early } \\
\text { weaning and } \\
\text { behavioral testing }\end{array}$ & R6/2 (HD) & $\begin{array}{l}\checkmark \\
\times\end{array}$ & $\begin{array}{l}\text { Increased in the survival of the first } 50 \% \text { of } \\
\text { mice to die } \\
\text { No change in body weight loss rate }\end{array}$ & $\begin{array}{l}\text { Carter et al. } \\
2000[118]\end{array}$ \\
\hline $\begin{array}{l}\text { Enhanced diet }+ \\
\text { involvement in a } \\
\text { breeding program }\end{array}$ & R6/2 (HD) & $\begin{array}{l}\checkmark \\
\times\end{array}$ & $\begin{array}{l}\text { Increased in the survival of the first } 50 \% \text { of mice to die } \\
\text { Increased body weight loss rate }\end{array}$ & $\begin{array}{l}\text { Carter et al. } \\
2000[118]\end{array}$ \\
\hline Enhanced diet & R6/2 (HD) & $\begin{array}{l}\checkmark \\
\times\end{array}$ & $\begin{array}{l}\text { Decreased body weight loss rate; prolonged } \\
\text { life span; increased hind limb grooming and burrowing } \\
\text { No change in open field phenotype }\end{array}$ & $\begin{array}{l}\text { Carter et al. } \\
2000[118]\end{array}$ \\
\hline $\begin{array}{l}\text { Minimally enriched } \\
\text { living conditions } \\
\text { (food pellets on the } \\
\text { cage floor+a } \\
\text { cardboard tube }\end{array}$ & R6/2 (HD) & $\begin{array}{l}\checkmark \\
\times\end{array}$ & $\begin{array}{l}\text { Increased rotarod performance; not significant } \\
\text { trend toward increase of the grip strength } \\
\text { No change in body weight loss rate; no } \\
\text { change in brain weight loss }\end{array}$ & $\begin{array}{r}\text { Hockly et al. } \\
2002[119]\end{array}$ \\
\hline $\begin{array}{l}\text { Highly enriched living } \\
\text { conditions (larger cages, } \\
\text { mixed genotypes, maize } \\
\text { fibers, paper strips, } \\
\text { cellulose pads, and } \\
\text { cotton wool; running } \\
\text { wheels and other toys) }\end{array}$ & R6/2 (HD) & $\checkmark$ & $\begin{array}{l}\text { Increased rotarod performance; increased } \\
\text { grip strength at endpoint; not significant } \\
\text { trend toward increase of the striatal volume; } \\
\text { increased peristriatal cerebral volume } \\
\text { No change in body weight loss rate; no change } \\
\text { in brain weight loss; no change in striatal and } \\
\text { cortical aggregate densities }\end{array}$ & $\begin{array}{r}\text { Hockly et al. } \\
2002[119]\end{array}$ \\
\hline $\begin{array}{l}\text { Voluntary physical } \\
\text { xercise (running wheels) }\end{array}$ & R6/2 (HD) & $x$ & $\begin{array}{l}\text { No change in proliferation of hippocampal } \\
\text { cells in } \mathrm{R} 6 / 2 \text { mice; no change in number of } \\
\text { neural precursor cells }(\mathrm{DCX}+\text { ) in the } \mathrm{DG} \text { of } \\
\text { R } 6 / 2 \text { mice; no change in the total number } \\
\text { of newly generated neurons }\end{array}$ & $\begin{array}{l}\text { Kohl et al. } \\
2007[133]\end{array}$ \\
\hline $\begin{array}{l}\text { Environmental } \\
\text { enrichment cages } \\
\text { (playground/no handling) }\end{array}$ & R6/2 (HD) & $\begin{array}{l}\checkmark \\
\times\end{array}$ & $\begin{array}{l}\text { Increased activity; prolonged life span } \\
\text { No change in overall cognitive performance } \\
\text { of R6/2 mice in morris water maze } \\
\text { (sex-dependent improvement in some tasks); } \\
\text { sex-specific mix of beneficial and detrimental } \\
\text { effects on body weight loss }\end{array}$ & $\begin{array}{l}\text { Wood et al. } \\
2010 \text { [129] }\end{array}$ \\
\hline $\begin{array}{l}\text { Environmental } \\
\text { enrichment cages } \\
\text { (playground/ handling) }\end{array}$ & R6/2 (HD) & $\begin{array}{l}\checkmark \\
\times\end{array}$ & $\begin{array}{l}\text { Increased activity } \\
\text { No change in overall cognitive performance } \\
\text { of R6/2 mice in morris water maze } \\
\text { (sex-dependent improvement in some tasks); } \\
\text { sex-specific mix of beneficial and } \\
\text { detrimental effects on body weight loss; } \\
\text { shortened life span (males) }\end{array}$ & $\begin{array}{l}\text { Wood et al. } \\
2010 \text { [129] }\end{array}$ \\
\hline $\begin{array}{l}\text { Motor stimulation } \\
\text { (enforced physical } \\
\text { exercise on the rotarod) }\end{array}$ & R6/2 (HD) & $\begin{array}{l}\checkmark \\
\times\end{array}$ & $\begin{array}{l}\text { Increased rotarod performance (females only) } \\
\text { Decreased body weight loss rate; no change in } \\
\text { survival; no change in cognitive function (Lashley } \\
\text { maze performance) }\end{array}$ & $\begin{array}{l}\text { Wood et al. } \\
2011[127]\end{array}$ \\
\hline $\begin{array}{l}\text { Cognitive stimulation } \\
\text { (training in the OX maze) }\end{array}$ & R6/2 (HD) & $\checkmark$ & $\begin{array}{l}\text { Increased cognitive function in males (Lashley } \\
\text { maze performance); prolonged life span (males); } \\
\text { sex-specific mix of beneficial and detrimental } \\
\text { effects on body weight loss; increased rotarod } \\
\text { performance (females) }\end{array}$ & $\begin{array}{l}\text { Wood et al. } \\
2011[127]\end{array}$ \\
\hline $\begin{array}{l}\text { Mixed stimulation } \\
\text { (access to a playground) }\end{array}$ & R6/2 (HD) & $\begin{array}{l}\checkmark \\
\times\end{array}$ & $\begin{array}{l}\text { Increased rotarod performance } \\
\text { No change in body weight loss rate; no } \\
\text { change in cognitive function (Lashley maze } \\
\text { performance); shortened life span (males) }\end{array}$ & $\begin{array}{l}\text { Wood et al. } \\
2011[127]\end{array}$ \\
\hline
\end{tabular}


and colleagues reported increased BDNF levels in the mouse hippocampus and striatum [121], Glass and colleagues showed that an enriched environment reduced the depletion of cannabinoid CB1 receptors [120], and Lazic demonstrated that improved conditions may affect neurogenesis [122]. However, recent reports using microarray profiling have not confirmed the previous observations and have shown no specific changes in enrichment-related gene expression in either transgenic or wild-type mice. In the same work, a nonsignificant trend toward the preservation of downregulated neurotransmitter receptors in the striatum of environmentally enriched mice was observed [126]. Similarly, motor training does not enhance hippocampal neurogenesis in R6/2 mice and does not rescue the deficits of BDNF expression in R6/1 mice $[123,133]$. The complex character of the environmental modulation methods, consisting of many unspecified motor and cognitive stimuli whose effects may overlap and act synergistically, may generate numerous variables that influence the experimental outcome. Further studies separating the individual elements of environmental enrichment are required to assess their contributions to the overall effect and determine the relevant mechanisms.

\section{Target: Aberrant Neurotransmission and Excitotoxicity}

The hypothesis that a pathogenic mechanism in HD may depend on excitotoxic neuronal damage arose from experiments where exogenous excitotoxins, such as kainic acid and quinolinic acid (QUIN), were applied by direct injection into the healthy rodent striatum, which produced a behavioral phenotype and cell damage pattern that were reminiscent of HD (for review [134]). Quinolinic acid, a selective $N$-methylD-aspartate (NMDA) receptor agonist, is useful because its injection selectively affects medium spiny neurons (MSNs), and most of the interneurons remain intact [135]. Excitotoxic neuronal injury in response to the injection of quinolinic acid affects cells that have NMDA receptors (NMDARs) on the cell membrane; these cells are physiologically excitable and may be considered healthy neuronal cells. Moreover, the excitotoxic injury in the QUIN model happens in healthy striata where the connectivity of the corticostriatal pathway is intact (developing young animals where the corticostriatal pathway is not fully established are resistant to QUIN excitotoxicity [136]). This chemical QUIN-evoked model was used to investigate $\mathrm{HD}$ in the absence of an identified causative gene and a lack of genetic mouse models, and although these experiments were performed almost 30 years ago, why MSNs are selectively vulnerable in HD is still unknown. Once the R6/2, YAC72, and YAC128 models were generated, they revealed some aspects of the excitotoxic phenomenon, showing electrophysiological alterations in MSNs and cortical pyramidal neurons [137-144]. The electrophysiological changes in $\mathrm{HD}$ are biphasic between presymptomatic and symptomatic
HD phases and have opposite characteristics between MSNs and pyramidal neurons, and these changes include both excitatory and inhibitory events. Based on these findings, it has been proposed that the connectivity in the corticostriatal pathway is disrupted in HD [145]. A sign of this connectivity loss is the lack of an excitotoxic response in symptomatic R6/2 and YAC128 models following the injection of QUIN [137].

Excitotoxicity is initiated by a glutamate receptormediated, excessive influx of $\mathrm{Ca}^{2+}$ ions into the neuronal cells, which subsequently may lead to the cascade of destructive events. It is still elusive why neurons that express a polyglutamine protein are more vulnerable to the endogenous excitotoxic insult. One possible explanation is that deregulation of the kynurenine pathway leads to elevated levels of endogenous excitotoxins [146]. Alterations in the metabolism and transport of glutamate or the oversensitivity of glutamate receptors in affected neurons may also contribute to the observed vulnerability [134].

\section{NMDA Receptors}

Although the central role of NMDA receptors in pathogenesis of HD is well established [147], the receptors were deemed poor therapeutic targets because of their essential physiological role. However, it has been recently discovered that the extrasynaptic pool of NMDARs mediates the deleterious effects of glutamate in neurons, whereas synaptically localized NMDA receptors do not induce $\mathrm{Ca}^{2+}$ overload or toxic cellular effects [148-151]. Two studies have demonstrated that selectively blocking extrasynaptic NMDA receptors with low concentrations of memantine, an NMDAR blocker, may represent a novel therapeutic strategy for HD; these studies have also shown that high concentrations of memantine block all NMDA receptors and do not produce beneficial therapeutic effects in transgenic mice $[149,150]$.

Subcutaneous injection of an NR2B-selective NMDA receptor antagonist does not relieve any disease phenotypes in R6/2 mice [152]. NMDA-NR2B receptors are believed to be located extrasynaptically; however, because the study on R6/2 mice used high doses of NR2B antagonists, the whole pool of NMDA receptors may have been inhibited, which is not beneficial $[149,152]$. In addition, the low-affinity NMDA antagonist remacemide has beneficial effects on motor performance in N171-82Q mice but has no effect on survival [28, 153]. Instead, beneficial effects, such as increased survival, have been shown in R6/2 and N171-82Q animals that were treated with remacemide combined with coenzyme Q10 [154].

\section{Other Receptors}

Other receptors that are present in the membranes of MSNs, such as the adenosine $\mathrm{A}_{2 \mathrm{~A}}$ receptor and metabotropic glutamate receptors mGluR5 and mGluR2 may also be possible 
targets for providing neuronal protection in HD [155-158]. For instance, treatment with CGS21680, an $\mathrm{A}_{2 \mathrm{~A}}$ agonist, ameliorates motor and neuropathological phenotypes and reduces hyperglycemia in R6/2 mice $[157,159]$. The metabotropic glutamate receptors modulate glutamate-mediated excitotoxicity by controlling membrane enzymes and second messenger systems. The mGluR5 antagonist MPEP and the mGluR2 agonist LY379268 modify disease progression and increase survival in the R6/2 model $[160,161]$. Moreover, interfering with glutamatergic neurotransmission by increasing the expression of glutamate transporter protein GLT-1 may be beneficial in HD mouse models $[162,163]$. The upregulation of glutamate transporters in astroglia following treatment with PACAP, EGF, or TGF- $\alpha$ presents a potential therapeutic option in neurodegenerative diseases $[164,165]$. Other therapeutic options include using reuptake inhibitors or supplying neurotransmitter precursors to interfere with other excitatory and inhibitory neurotransmitters, such as dopamine and GABA, and serotonin [166-169].

\section{Kynurenine Pathway}

The kynurenine pathway (KP) is a major route of tryptophan catabolism in mammalian cells and contains three important neuroactive metabolites: quinolinic acid, its precursor 3hydroxykynurenine (3-HK) and kynurenic acid (KYNA) [170]. Because of their properties - the potent excitotoxicity of QUIN, the generation of reactive oxygen species by 3-HK, and the neuroprotective abilities of KYNA - all of these compounds may participate in HD pathogenesis [146, 171, 172]. For detailed mechanisms of neurodegeneration associated with kynurenine pathway see the following references $[134,146]$.

Therapeutic interventions that modulate the production of KP metabolites have recently been shown to have beneficial effects in a drosophila model of Huntington disease [173] and in mouse models of Alzheimer disease and Huntington disease [174]. In these reports, researchers inhibited kynurenine 3-monooxygenase (KMO, an enzyme that converts kynurenine into 3-HK), which resulted in the increased synthesis of a neuroprotective KYNA metabolite and decreased extracellular glutamate levels. Interestingly, JM6, a KMO inhibitor that was used in the mouse studies, does not trigger these effects directly in central nervous system (CNS) cells because of its inability to cross the blood-brain barrier. Instead, JM6 inhibits KMO in blood cells, which results in an increased level of circulating kynurenine, active transport of kynurenine through the blood-brain barrier, and the subsequent conversion of kynurenine into KYNA in CNS cells. R6/2 mice that were orally administered JM6 did not exhibit cortical or striatal synaptic losses or inflammatory microglial responses, and they lived longer than untreated R6/2 animals. No changes in the abundance or sizes of huntingtin inclusions were recorded [174].
Target: Mitochondrial Dysfunction

Numerous observations in postmortem HD brains and animal models of HD support the idea that mitochondrial impairment may contribute to the pathogenesis and neurotoxicity of HD [175-179]. Subsequent studies revealed the existence of several different mechanisms that directly or indirectly link mitochondrial dysfunction with the mutant huntingtin protein (Fig. 5). Among them, the most extensively studied and the most plausible mechanisms are: transcriptional deregulation of nuclear-encoded mitochondrial proteins, $\mathrm{Ca}^{2+}$ handling impairment, and trafficking deficits.

Mutant huntingtin induces transcriptional deregulation of nuclear-encoded mitochondrial proteins by binding to several transcription factors, such as p53, CBP, TAFII130 and SP1, and altering their physiological functions. By interfering with CREB function, huntingtin downregulates the expression of PPAR $\gamma$ co-activator- $1 \alpha$ (PGC- $1 \alpha)$, thus deregulating the expression of numerous proteins that are

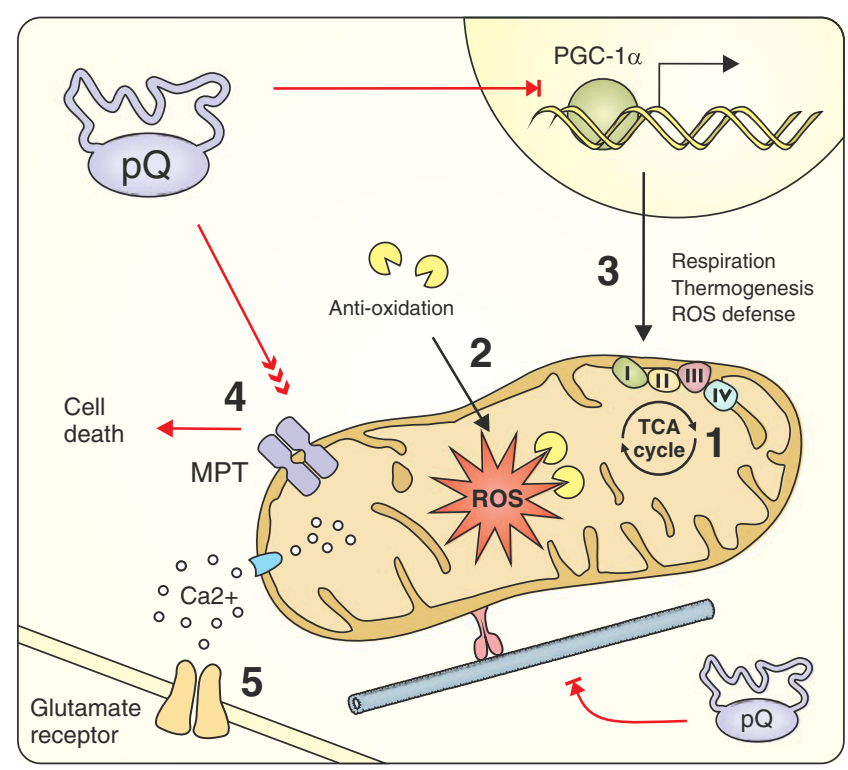

Fig. 5 The therapeutic strategies targeting mitochondrial dysfunction induced by expanded polyQ proteins. By interfering with CREB function, huntingtin downregulates the expression of PGC- $1 \alpha$ and induces transcriptional deregulation of nuclear-encoded mitochondrial proteins that are involved in respiration, thermogenesis, and ROS defense. Mutant huntingtin has been proposed to interact with the outer mitochondrial membrane to significantly decrease the mitochondrial $\mathrm{Ca}^{2+}$ capacity and directly induce MPT pore opening. These alterations can cause increased vulnerability to glutamate receptor-mediated excitotoxic stimuli. Finally, mutant huntingtin causes defects in mitochondrial trafficking through long dendritic and axonal projections. Mitochondria-related therapeutic strategies include compensating for energy deficits (1) and oxidative stress (2) caused by mitochondrial dysfunction; restoring the altered transcription of mitochondrial factors (3); inhibiting the mitochondrial permeability transition (4); and administering NMDAR inhibitors to protect against excitotoxicitymediated cell death (5). PPAR $\gamma$ co-activator- $1 \alpha(P G C-1 \alpha)$, reactive oxygen species $(R O S)$, mitochondrial permeability transition $(M P T)$ 
essential for proper mitochondrial operation, including reactive oxygen species (ROS)-scavenging enzymes, respiratory chain components, and thermogenic factors [180, 181].

When the mitochondrial $\mathrm{Ca}^{2+}$-buffering capacity is overloaded, mitochondria lose their membrane potential and open the mitochondrial permeability transition (MPT) pores, which results in the activation of cellular death pathways [182]. Mutant huntingtin may interact with the outer mitochondrial membrane and directly induce MPT pore opening. Furthermore, mutant huntingtin significantly decreases the $\mathrm{Ca}^{2+}$ threshold necessary to initiate this cascade [183]. Increased mitochondrial sensitivity to intracellular calcium concentrations may therefore explain the excitotoxicitymediated death of neuronal cells that contain mutant huntingtin.

Neurons with long dendritic and axonal projections are particularly dependent on proper trafficking of mitochondria to distant energy-consuming sites. One of the normal functions of wild-type huntingtin is interacting with numerous trafficking mediators to regulate intracellular microtubulemediated transport [184]. It has been demonstrated that mutant huntingtin can negatively influence the trafficking regulation network and cause defects in organelle movement [185]. In addition, large intracellular aggregates of mutant huntingtin can physically block the transport of mitochondria along these projections [186].

\section{Energy Deficit and Oxidative Stress}

Mitochondria-related therapeutic strategies that have been examined in mouse models of Huntington disease were primarily designed to compensate for energy deficits and oxidative stress caused by mitochondrial dysfunction (Fig. 5). Several studies tested coenzyme Q10 (CoQ10), an essential cofactor of the electron transport chain and potent free radical scavenger, both alone and in multidrug therapies. Schilling and colleagues evaluated the effects of CoQ10 and the excitotoxic protector remacemide on the phenotype of N171-82Q mice. They observed an improvement in rotarod performance and a rescue from body weight loss but not from premature death $[28,153]$. The Beal's and Ferrante's groups also detected significant rescue of motor impairment and neuropathology in addition to extensions of the lifespans of R6/2 and N171-82Q animals by as much as 20-30 \% upon treatment with CoQ10 alone [187] or in conjunction with remacemide [154], minocycline [188], or creatine [189] (Table 4). However, a recent paper by Menalled and colleagues questioned the beneficial effects of CoQ10 (and minocycline; see "Target: Apoptosis" section) by showing a lack of improvement in survival, body weight, rotarod performance, open field performance, and climbing performance following oral administration of $0.2 \% \mathrm{CoQ} 10$. Treatment with a higher dose $(0.6 \%)$ had additional negative effects that were specific to HD (Table 4) [190]. These contradictory results may have been caused by methodological variations in testing paradigms and by differences in animal husbandry like access to food or housing conditions. Additionally, high molecular weight, insolubility in water, and limited solubility in lipids are reasons for the poor absorption and brain penetration of orally administered CoQ10, so its bioavailability is strongly dependent on the formulation [191]. Various formulation strategies for improving CoQ10 bioavailability are currently under intensive development [192].

Other energy compensators, such as dichloroacetate and lipoic acid (which are pyruvate dehydrogenase complex stimulators), triacetyluridine, creatine, or modified diet regimes, also have beneficial effects on motor and neuropathological phenotypes, prolong the shortened lifespan and rescue body weight loss in R6 and N171-82Q mice [107, 111, 118, 193-198].

Damaged mitochondria lose their free radical scavenging properties, which leads to elevation of free radical concentration [199]. To mitigate this aspect of HD pathogenesis, several antioxidant approaches have been extensively investigated. In addition to having anti-oxidative properties, the chemical compounds NDGA and TUDCA also mitigate mitochondrial insufficiency and toxicity and improve the phenotype of R6/2 mice $[200,201]$. Other potent free radical scavengers, such as BN82451, ascorbate and L-carnitine, or triterpenoids and fumaric acid, which indirectly stimulate the Nrf2 antioxidative signaling pathways, reduce ROS and have a high therapeutic potential for HD treatment [202-206].

\section{Transcriptional Deregulation of Mitochondrial Proteins}

Approaches that restore the altered transcription of mitochondrial factors target the activity of PGC- $1 \alpha$, a key transcriptional co-activator involved in energy homeostasis, glucose metabolism, and mitochondrial biogenesis [180]. Chaturvedi and colleagues mimicked the effects of endurance exercise training by treating NLS-N171-82Q mice with GPA (betaguanidinopropionic acid), which reduces phosphocreatine and ATP levels. They found that muscles in HD mice cannot overcome an energetic stress by inducing the PGC- $1 \alpha$ pathway, as it happens in muscles of wild-type mice. This deficiency is caused by alterations located upstream of PGC- $1 \alpha$ that impair the activation of the PGC- $1 \alpha$-inducing AMPK pathway, the sensor for energy regulation. Expression of exogenous PGC- $1 \alpha$ directly in the muscles of NLS-N171-82Q mice increases the oxidative capacities of the muscles and reverses the blunted response to GPA treatment [207].

PGC- $1 \alpha$ activity is also regulated through its deacetylation by NAD-dependent deacetylase sirtuin-1 (Sirt1). Sirt1 activity can be enhanced by resveratrol, a natural polyphenolic compound. Ho and colleagues found that orally administered resveratrol increased both PGC- $1 \alpha$ activity and 
Table 4 Therapeutic approaches using CoQ10 in mouse models of polyQ diseases

\begin{tabular}{|c|c|c|c|c|c|}
\hline Drug & Route/Dose & Model & & Therapeutic outcomes & Reference \\
\hline CoQ10/remacemide & $\begin{array}{l}\text { Food supplemented with } 0.2 \% \\
\text { of CoQ10 }(500 \mathrm{mg} / \mathrm{kg} / \text { day }) \\
\text { and } 0.007 \% \text { of remacemide } \\
(17.5 \mathrm{mg} / \mathrm{kg} / \text { day })\end{array}$ & N171-82Q (HD) & $\checkmark$ & $\begin{array}{l}\text { Improved rotarod performance; } \\
\text { decreased body weight loss rate } \\
\text { No change in survival; no change } \\
\text { in inclusion formation }\end{array}$ & $\begin{array}{l}\text { Schilling et al. } \\
2001[153]\end{array}$ \\
\hline CoQ10 & $\begin{array}{l}\text { Powdered food supplemented } \\
\text { with } 0.2 \% \text { of CoQ10 } \\
\text { (500 } \mathrm{mg} / \mathrm{kg} / \text { day) }\end{array}$ & N171-82Q (HD) & $\begin{array}{l}\checkmark \\
\times\end{array}$ & $\begin{array}{l}\text { Improved rotarod performance } \\
\text { Shortened life span (powdered } \\
\text { food formulations effect) }\end{array}$ & $\begin{array}{l}\text { Schilling et al. } \\
2004[28]\end{array}$ \\
\hline CoQ10/remacemide & $\begin{array}{l}\text { Food supplemented with } 0.2 \% \\
\text { of CoQ10 }(400 \mathrm{mg} / \mathrm{kg} / \text { day }) \\
\text { and } 0.007 \% \text { of remacemide } \\
(14 \mathrm{mg} / \mathrm{kg} / \text { day })\end{array}$ & N171-82Q (HD) & $\checkmark$ & $\begin{array}{l}\text { Attenuated body weight loss; } \\
\text { prolonged life span }\end{array}$ & $\begin{array}{l}\text { Ferrante et al. } \\
2002[154]\end{array}$ \\
\hline CoQ10/remacemide & $\begin{array}{l}\text { Food supplemented with } 0.2 \% \\
\text { of CoQ10 (400 mg/kg/day) } \\
\text { and } 0.007 \% \text { of remacemide } \\
\text { (14 } \mathrm{mg} / \mathrm{kg} / \text { day }) \text { - separate } \\
\text { or combined }\end{array}$ & R6/2 (HD) & $\checkmark$ & $\begin{array}{l}\text { Improved rotarod performance; } \\
\text { attenuated body weight loss; prolonged } \\
\text { life span; delayed brain weight loss; } \\
\text { attenuated gross brain atrophy and } \\
\text { ventricular enlargement; attenuated } \\
\text { neuronal atrophy; reduced number } \\
\text { of striatal aggregates }\end{array}$ & $\begin{array}{l}\text { Ferrante et al. } \\
2002[154]\end{array}$ \\
\hline CoQ10 & $\begin{array}{l}\text { Food supplemented } 1,000 \\
5,000,10,000, \text { or } 20,000 \\
\mathrm{mg} / \mathrm{kg} / \text { day (Chemco) }\end{array}$ & R6/2 (HD) & $\checkmark$ & $\begin{array}{l}\text { Prolonged life span (dose dependent); } \\
\text { reduced body weight loss; improved } \\
\text { rotarod phenotype; increased forelimb } \\
\text { strength; attenuated gross brain size } \\
\text { decline and striatal atrophy; reduced } \\
\text { aggregate formation }\end{array}$ & $\begin{array}{l}\text { Smith et al. } \\
2006[187]\end{array}$ \\
\hline CoQ10 & $\begin{array}{l}\text { Food supplemented } 400, \\
1,000, \text { and } 2,000 \mathrm{mg} / \mathrm{kg} / \text { day } \\
\text { (Tishcon) }\end{array}$ & R6/2 (HD) & $\checkmark$ & $\begin{array}{l}\text { Prolonged life span (dose dependent); } \\
\text { reduced body weight loss; improved } \\
\text { rotarod phenotype }\end{array}$ & $\begin{array}{l}\text { Smith et al. } \\
2006 \text { [187] }\end{array}$ \\
\hline CoQ10/minocycline & $\begin{array}{l}\text { Food supplemented with } 0.2 \% \\
\text { of CoQ10 and intraperitoneal } \\
\text { injection of minocycline } \\
(5 \mathrm{mg} / \mathrm{kg} / \text { day }) \text { - separate } \\
\text { or combined }\end{array}$ & R6/2 (HD) & $\checkmark$ & $\begin{array}{l}\text { Prolonged life span; improved rotarod } \\
\text { phenotype; reduced body weight loss } \\
\text { (CoQ10 specific); attenuated gross brain } \\
\text { atrophy and ventricular enlargement; } \\
\text { attenuated neuronal atrophy; reduced } \\
\text { aggregate formation (CoQ10 specific); } \\
\text { attenuated the microglial response } \\
\text { (minocycline specific) }\end{array}$ & $\begin{array}{l}\text { Stack et al. } \\
2006[188]\end{array}$ \\
\hline CoQ10/creatine & $\begin{array}{l}\text { Food supplemented with } 1 \% \\
\text { of CoQ10 and } 2 \% \text { of } \\
\text { creatine-separate or } \\
\text { combined }\end{array}$ & R6/2 (HD) & $\checkmark$ & $\begin{array}{l}\text { Improved rotarod performance; } \\
\text { prolonged life span }\end{array}$ & $\begin{array}{l}\text { Yang et al. } \\
2009 \text { [189] }\end{array}$ \\
\hline CoQ10 & $\begin{array}{l}\text { Food supplemented with } \\
0.2 \% \text { of CoQ10 }\end{array}$ & R6/2 (HD) & $x$ & $\begin{array}{l}\text { No change in survival, body weight and } \\
\text { rotarod performance; no change in rearing } \\
\text { frequency and climbing performance; } \\
\text { transient deleterious effects in the open } \\
\text { field and grip strength; }\end{array}$ & $\begin{array}{l}\text { Menalled et al. } \\
2010 \text { [190] }\end{array}$ \\
\hline CoQ10 & $\begin{array}{l}\text { Food supplemented with } \\
0.6 \% \text { of CoQ10 }\end{array}$ & R6/2 (HD) & $x$ & $\begin{array}{l}\text { No change in survival, rotarod performance, } \\
\text { grip strength performance, and climbing; } \\
\text { transiently decreased body weight, } \\
\text { locomotor activity, and rearing in } \mathrm{R} 6 / 2\end{array}$ & $\begin{array}{l}\text { Menalled et al. } \\
2010 \text { [190] }\end{array}$ \\
\hline
\end{tabular}

the expression of its direct downstream targets, NRF-1 and UPC-1 (both of which regulate mitochondrial function) in N171-82Q transgenic mice. However, this improvement was only observed in brown adipose tissue. As a result of insufficient striatal penetration, resveratrol could not induce similar effects in neurons; thus, the treatment resulted in a lack of improvement in motor performance, survival, and striatal atrophy [208]. A similar strategy, leading to an increase in PGC- $1 \alpha$ activity, was applied by Hathorn and colleagues. They used nicotinamide, an Sirt1 inhibitor, and postulated that it can also act as an Sirtl activator. In contrast to Ho's report, nicotinamide improved HDassociated motor deficits [108]. However, because nicotinamide is not a specific drug (it can also increase BDNF expression), PGC- $1 \alpha$-independent mechanisms may also contribute to the observed improvement. Recently, two studies showed that Sirtl exerts neuroprotection in HD mouse brains by activating pro-survival transcription factors/ 
coactivators, including Foxo3a and TORC1. Mutant huntingtin interacts with Sirt1 and inhibits its deacetylase activity, which results in hyperacetylation of Sirt1 substrates and repressed transcription of pro-survival genes. Notably, Sirt1 overexpression restores the aberrant acetylation status of Sirt1 substrates, promotes the BDNF and DARPP32 expression, and improves HD phenotype in N171-82Q and BACHD mice [209, 210].

Finally, Chiang and colleagues showed that treatment of R6/2 mice with thiazolidinedione to activate pathways mediated by PPAR $\gamma$ (a nuclear receptor that acts upstream of the PGC-1 $\alpha$ gene), can rescue the progressive weight loss, deterioration of motor skills, formation of mutant HTT aggregates and reduced lifespan phenotypes. Similar to nicotinamide treatment, thiazolidinediones also induce the expression of two neuroprotective proteins, BDNF and Bcl-2 [109].

\section{Calcium-buffering Capacity}

The importance of mitochondrial permeability in the transition to cell death has been tested twice in R6/2 mice. Administration of nortriptyline, a strong inhibitor of MPT, delays disease onset but also accelerates disease progression once the phenotype appears [211]. In addition, Perry et al. obtained discouraging results when they crossbred R6/2 mice with cyclophilin D (CypD)-deficient animals. CypD is a structural component of the MPT pore, and knockout of the gene encoding CypD increases mitochondrial $\mathrm{Ca}^{2+}$ buffering, thereby protecting cells from calcium overload. However, increasing the mitochondrial $\mathrm{Ca}^{2+}$ capacity fails to ameliorate the HDrelated behavioral and neuropathological phenotypes [212].

\section{Target: Apoptosis}

Aberrant interactions between polyQ proteins and the components of apoptotic pathways have been reported in patients' brains and in cellular and animal models (Fig. 6). The presence of mutant huntingtin results in mitochondrial cytochrome c release, followed by the activation of caspases 9 and 3 and the upregulation and/or activation of caspases 1,2,3,6,7, and 8 in the brains of humans with HD and in mouse models of HD [213-218]. Expanded ataxin-3 and ataxin-7 upregulate Bax and PUMA (which are pro-apoptotic proteins) and downregulate $\mathrm{Bcl}-\mathrm{xL}$ (which is an anti-apoptotic protein), which may subsequently lead to the release of the apoptogenic proteins from mitochondria [219-221]. Moreover, the expression of androgen receptors in cultured neurons induces the Bax-dependent apoptotic cascade initiated by the JNK signaling pathway in response to polyQ-mediated stress [222]. These observations suggest that polyQ proteins may interfere with both the intrinsic (mitochondria-mediated) and extrinsic (receptor-mediated) apoptotic pathways. Additionally, several polyQ proteins that undergo proteolytic cleavage by cellular

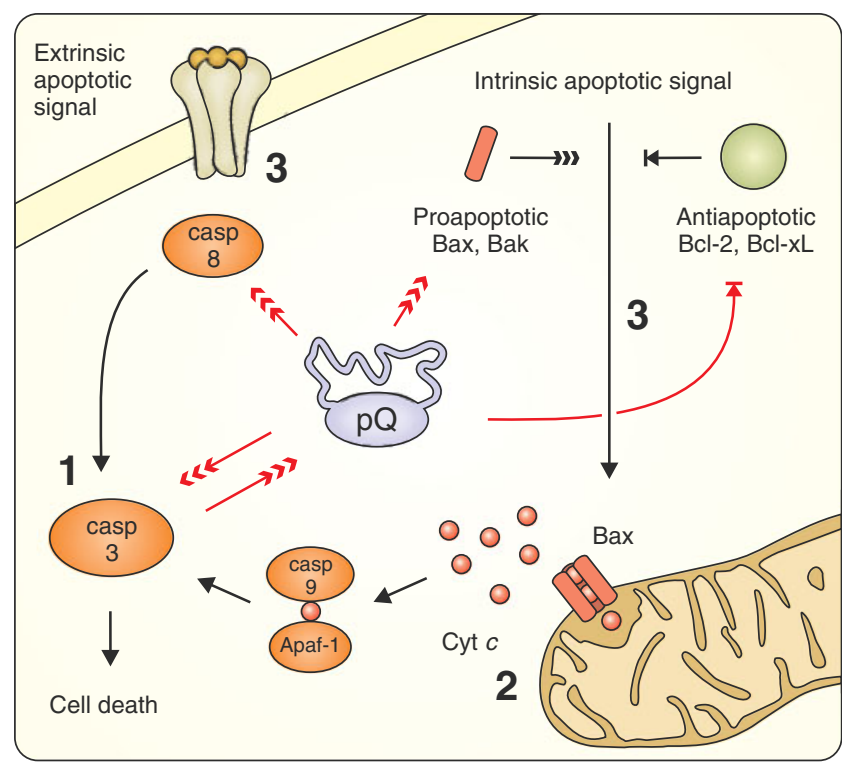

Fig. 6 Anti-apoptotic therapeutic strategies target aberrant interactions between polyglutamine proteins and the components of apoptotic pathways. PolyQ proteins cause the upregulation and/or activation of several caspases, upregulate pro-apoptotic proteins and downregulate anti-apoptotic factors, which may subsequently lead to the release of apoptogenic proteins from mitochondria. Several polyQ proteins undergo proteolytic cleavage by caspases, which results in the production of toxic truncated protein fragments. Therapeutic approaches tested in mouse models include the inhibition of caspase functions (1), the inhibition of mitochondrial release of cytochrome $c$ and subsequent intrinsic apoptotic pathway activation (2), and the modulation of the initiation of apoptotic signals (3). Cytochrome c (Cyt c), apoptotic protease activating factor 1 (Apaf-1)

proteases, such as huntingtin, ataxin- 3 and $-7, A R$ and atrophin-1, are also substrates for caspases [223-227]. Truncated fragments of these proteins may play crucial roles in the pathogenesis of each disease because they are more toxic than their full-length forms. For example, huntingtin containing a mutation at the caspase- 6 cleavage site was unable to induce neurodegeneration in HD YAC128 transgenic mice [228]. The mice expressing the N-terminal 586 aa caspase fragment of HTT show cytoplasmic inclusions and neurological phenotype milder than R6/2. This indicates that further cleavage is needed to worsen the phenotype and evoke more intensive nuclear accumulation $[229,230]$.

Although molecular markers of apoptosis are easily detectable even before gross neuronal loss, typical cellular apoptotic features and the presence of neurons undergoing apoptosis have rarely been reported in mouse models. It is widely accepted that expanded polyglutamine proteins may also induce other forms of cellular death [231]. Differences in spatiotemporal expression patterns and polyQ protein contexts between humans and mouse models may influence the proportion of individual death mechanisms that are activated and, as a result, apoptosis may be masked in polyQ mice, even with the activation of apoptotic mediators. 


\section{Minocycline Treatment}

The efficacy of minocycline in Huntington disease treatment has been extensively debated over the last decade. Initial encouraging results were obtained by Ona and colleagues who showed that blocking caspase function could delay both disease onset and mortality in R6/2 mice [232]. The same group found that minocycline inhibits caspase-1, caspase-3, and iNOS activities in HD animals and observed a reduction in both disease progression and mortality of R6/ 2 animals [214]. The beneficial effect of minocycline was thought to be caused by the attenuation of HD-mediated induction of the caspase cascade and decreased production of toxic HTT fragments [214, 233]. However, Bates's laboratory was unable to replicate those findings despite using the same drug and mouse model but with different dosing and different administration routes [27]. Subsequent studies performed on R6/2, N171-82Q, and 3-nitroproprionic acid HD models demonstrated that minocycline treatment had either favorable efficacy [188] or no efficacy [234, 235]
(Table 5). Recently, Menalled and colleagues attempted to reevaluate the preclinical effects of minocycline (and coenzyme Q10) using the R6/2 model. A low dose of minocycline (Table 5) induced some transient beneficial effect, although it was not comparable to the results published by Chen and colleagues and Stack and colleagues. Higher doses (Table 5) resulted in HD-specific toxicity (including reduced survival rates and body weights) and lack of amelioration of the disease phenotype [190], which confirmed previous observations [27]. The reason for these discrepancies is unclear and may be explained by differences in husbandry conditions, drug preparation, or methodological variations in testing paradigms [190, 236].

At the same time, four minocycline clinical trials were being conducted. A small study of 14 patients showed stabilization of general motor and neuropsychological function after 2 years of treatment [237]. Another short-term pilot study, designed to examine the safety of orally administered minocycline at the dosage of $200 \mathrm{mg} /$ day, revealed

Table 5 Therapeutic approaches using minocycline in mouse models of polyQ diseases

\begin{tabular}{|c|c|c|c|c|c|}
\hline Drug & Route/Dose & Model & & Therapeutic outcomes & Reference \\
\hline Minocycline & Intraperitoneal, $5 \mathrm{mg} / \mathrm{kg} /$ day & R6/2 (HD) & $\checkmark$ & $\begin{array}{l}\text { Prolonged life span; improved rotarod } \\
\text { performance } \\
\text { No change in body weight loss rate and } \\
\text { blood glucose level; no change in aggregate } \\
\text { formation and receptor-binding }\end{array}$ & $\begin{array}{l}\text { Chen et al. } \\
2000 \text { [214] }\end{array}$ \\
\hline Minocycline & $\begin{array}{l}1 \text { and } 5 \mathrm{mg} / \mathrm{mL} \text { in drinking } \\
\text { water, }(\sim 150 \text { and } 750 \mathrm{mg} / \mathrm{kg} / \text { day })\end{array}$ & R6/2 (HD) & $\checkmark$ & $\begin{array}{l}\text { Reduced elevated glucose levels } \\
\text { No change in body weight loss rate, rotarod } \\
\text { performance, and grip strength; no change in } \\
\text { aggregate formation; higher dose }(10 \mathrm{mg} / \mathrm{mL}) \\
\text { induced severe initial weight loss }\end{array}$ & $\begin{array}{l}\text { Smith et al. } \\
2003[27]\end{array}$ \\
\hline Minocycline & Intraperitoneal, $5 \mathrm{mg} / \mathrm{kg} /$ day & R6/2 (HD) & $\times$ & $\begin{array}{l}\text { Prolonged life span; improved rotarod } \\
\text { performance; attenuated gross brain atrophy } \\
\text { and ventricular hypertrophy; attenuated striatal } \\
\text { neuronal atrophy and microglial response; } \\
\text { therapeutic effect increased with the combined } \\
\text { minocycline/CoQ10 treatment } \\
\text { No change in body weight loss rate and } \\
\text { aggregate formation }\end{array}$ & $\begin{array}{l}\text { Stack et al. } \\
2006[188]\end{array}$ \\
\hline Minocycline & Intraperitoneal, $10 \mathrm{mg} / \mathrm{kg} /$ day & N171-82Q (HD) & $x$ & $\begin{array}{l}\text { No change in survival and body weight } \\
\text { loss rate; no change in rotarod and open } \\
\text { field performance; no change in striatal } \\
\text { atrophy, ventricle enlargement, and cortical } \\
\text { thickness }\end{array}$ & $\begin{array}{l}\text { Mievis et al. } \\
2007 \text { [235] }\end{array}$ \\
\hline Minocycline & Intraperitoneal, $5 \mathrm{mg} / \mathrm{kg} /$ day & R6/2 (HD) & $\begin{array}{l}\checkmark \\
\times\end{array}$ & $\begin{array}{l}\text { Transiently increased body weight, } \\
\text { locomotor activity, and rearing (males) } \\
\text { No change in survival, grip strength, rotarod } \\
\text { performance, and climbing phenotype; }\end{array}$ & $\begin{array}{l}\text { Menalled et al. } \\
2010 \text { [190] }\end{array}$ \\
\hline Minocycline & $\begin{array}{l}\text { Food supplemented with } 0.1 \% \\
\text { and } 0.375 \% \text { of minocycline } \\
(\sim 200 \text { and } 750 \mathrm{mg} / \mathrm{kg} / \text { day })\end{array}$ & R6/2 (HD) & $\begin{array}{l}\checkmark \\
\times\end{array}$ & $\begin{array}{l}\text { Transiently increased body weight and rearing } \\
(0.1 \%) \text {; minor and transient beneficial effect } \\
\text { on rotarod performance }(0.375 \%) \\
\text { Decreased survival (both doses); reduced body } \\
\text { weight and rearing }(0.375 \%) \text {; decreased open } \\
\text { field activity }(0.375 \%) \text {; no change in grip strength }\end{array}$ & $\begin{array}{l}\text { Menalled et al. } \\
2010 \text { [190] }\end{array}$ \\
\hline
\end{tabular}


that although there was a lack of medication-related side effects, there was also no significant motor improvement [238]. Similar results were obtained by the Huntington Study Group, although minocycline at 100 and $200 \mathrm{mg} /$ day induced a drop in platelet count and increase in blood urea nitrogen that were not clinically relevant [239]. Observed toxicity is consistent with other studies in humans where low doses of minocycline show no or minor toxicity, and high-dose treatment results in negative effects [240]. In ALS patients, dosages as high as $400 \mathrm{mg}$ of minocycline/ day increased mortality, gastrointestinal, and neurological adverse events [241]. Recent results from a futility study (which is used to determine whether phase III efficacy studies should be pursued) suggest that minocycline is ineffective in the treatment of HD [242].

\section{Other Treatment Targeting Apoptotic Pathway}

Methazolamide has been isolated in an in vitro screen from the library of 1,040 compounds for inhibitors of mitochondrial cytochrome $c$ release (and caspase activation). Methazolamide treatment results in the alleviation of motor and neuropathological phenotypes of R6/2 mice [243]. Expression of the P2X7 receptor, an ATP-gated cation channel that may mediate apoptosis in response to elevated $\mathrm{Ca}^{2+}$ levels, is increased as a consequence of polyQ-mediated transcriptional deregulation. Thus, inhibition of the P2X7 receptor by Brilliant Blue-G prevents neuronal apoptosis, reduces body weight loss, and improves motor deficits in R6/2 animals [244].

\section{Target: Transcriptional Deregulation}

The expression of expanded forms of polyQ proteins leads to transcriptional changes that can be detected in animal models and polyglutamine disease patients [245-249]. Transcriptional deregulation is a common phenomenon that occurs in polyglutamine and other neurodegenerative disorders. Deregulation affects genes that are responsible for neuroprotection and neuronal plasticity; genes that are involved in signaling pathways (including those leading to cellular death); genes that regulate the function of intracellular systems, such as in the mitochondria and in clearance pathways; and genes that are essential for neuronal communication [249]. Therefore, transcriptional aberrations may participate in or even induce other pathological mechanisms, and therapeutic strategies aimed at restoring an altered gene expression pattern may have great potential because they can produce beneficial effects through multiple mechanisms (Fig. 7).

\section{Transcription Factors}

The polyQ proteins, e.g., the androgen receptor and TATAbinding protein are well-known DNA-binding transcription

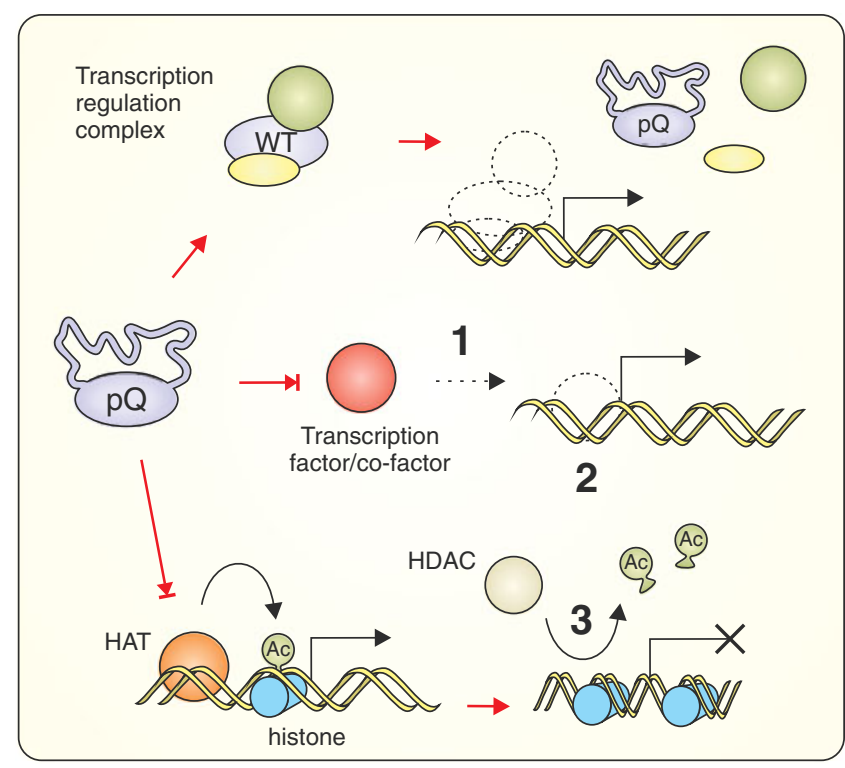

Fig. 7 Transcriptional deregulation in therapeutic strategies of polyQ diseases. PolyQ tract may influence the binding of polyQ proteins with other protein partners or DNA response elements. Expanded polyQ stretches may interact with or sequester transcription factors leading to the up- or downregulation of many genes. In particular, mutant polyQ proteins abnormally interact with HATs and/or HDACs, which results in the alteration of histone modification patterns and leads to transcriptional activation or inhibition at specific genomic loci. Therapeutic strategies include activation of transcription factors whose activities are reduced by polyQ proteins (1), modulation of transcription factor activity using DNA-binding anthracycline antibiotics (2), and restoration of altered transcription patterns through the modulation of nucleosome dynamics using HDAC inhibitors (3). PolyQ protein with normal polyglutamine stretch $(W T)$, histone acetyltransferase (HAT), histone deacetylase (HDAC), acetyl group ( $A c)$

factors. Moreover, ataxin-7 is a subunit of a STAGA transcriptional coactivator complex [250], and ataxin-1 interacts with and modulates the function of transcriptional coregulators [251-253]. Ataxin-3 is thought to repress transcription via histone-dependent chromatin remodeling [254, 255], and huntingtin modulates the expression of NRSE-controlled genes [79]. The polyglutamine mutations expressed in these proteins change their physiological properties by diminishing or enhancing their abilities to bind other protein partners or by changing their binding to DNA response elements, which ultimately results in the up- or downregulation of many genes. Expanded polyQ stretches may also endow mutant proteins with new abilities to interact with or to sequester transcription factors and cofactors that do not interact with proteins containing normal polyQ tracts (Fig. 7). This mechanism was observed in several studies that reported that polyQ stretches located in various proteins were able to modulate the activities of the transcription factors TAFII130, PQBP-1, p53, and Sp1 [221, 256-259]. The different polyQ proteins often share similar interactions with same transcription factors [249]. 
The strategy of restoring the activity of transcription factors that were deregulated and/or sequestered by mutant polyQ proteins was applied to a rat HD model and to striatal cell lines established from HdhQ111 knock-in mice. The overexpression of CA150 transcriptional regulator fully rescues the $109 \mathrm{Q} / 109 \mathrm{Q}$ striatal cell death in culture and delays striatum shrinkage and the degeneration of striatal cells in the lentiviral rat model of HD [260]. Similarly, an abnormal interaction between mutant huntingtin and Bcll1b, a zinc finger DNA-binding protein, is thought to contribute to the striatal transcriptional deficits that are observed in $\mathrm{HD}$, and overexpression of Bcl11b in $\mathrm{STHdh}^{\mathrm{Q} 111}$ cells partially reverses the expression changes of Bcl11b target genes [261].

\section{Chromatin Remodeling}

Mutant polyQ proteins often interact abnormally with histone acetyltransferases (HATs) and/or histone deacetylases (HDACs), altering physiological histone modification patterns thereby changing gene expression in the cell (for review [262]). The transcriptional coactivator CREBbinding protein (CBP) contains a HAT domain and interacts with several polyQ mutant causative proteins [263-266]. The inhibition of the acetyltransferase activity of CBP (as well as other HATs, such as p300, PCAF, or TIP60) may lead to hypo-acetylation of histones at several promoters and, consequently, to transcriptional inhibition at specific genomic loci [267].

In healthy cells, cAMP/CREB signaling often leads to the activation of "pro-survival" gene promoters. The polyQ disease mutant proteins may also recruit CREB, preventing the activation of genes. A possible therapy should involve the increase of the intracellular level of cAMP to induce the activation of more CREB molecules. Indeed, the administration of phosphodiesterase (PDE) inhibitors increases cAMP levels by inhibiting its degradation. In R6/2 mice, this kind of treatment using either the PDE type IV inhibitor rolipram [104, 268] or the PDE10E inhibitor TP-10 [105], improves the disease phenotypes.

HDAC Inhibitors The inhibition of HDAC activity appears to be the transcription-restoration strategy that has been most extensively tested in mouse models of polyQ diseases. Although HDAC inhibitors lack specificity because they can also disturb the expression of other, unrelated, genes, some of these inhibitors display promising therapeutic properties. Aliphatic acids, such as butyric, phenylbutyric and valproic acids, administered as sodium salt solutions, have been analyzed in SCA3 Q79, SBMA AR-97Q, DRPLA Atro 118Q and N171-82Q, and R6/2 HD animals [269-274]. These compounds are generally beneficial, restore the hypo-acetylation phenotype, and improve motor performance (Table 6). Despite significant improvements in numerous neuropathological phenotypes, sodium butyrate cannot reduce the amount of polyQ aggregates.

Another HDAC inhibitor, suberoylanilide hydroxamic acid (SAHA), administered orally in drinking water as cyclodextrin complex, strongly improves motor performance on the rotarod apparatus and decreases neuronal atrophy in R6/2 mice. Like sodium butyrate, SAHA rescues the global hypo-acetylation of histones and has no effect on polyQ aggregates [275]. Finally, Thomas and colleagues treated R6/2 mice (300Q) with a benzamide-type HDAC inhibitor, HDACi $4 \mathrm{~b}$. In an in vitro test, this compound had lower toxicity than previously tested HDAC inhibitors, and it prevented motor deficits and neurodegenerative processes in vivo even when treatment was begun after the onset of motor deficits. Microarray analysis revealed that HDACi $4 \mathrm{~b}$ treatment partially restored the expression changes that had been detected in R6/2 300Q brains [276].

Other Chromatin Remodeling Approaches The anthracycline antibiotics mithramycin and chromomycin directly bind to DNA sequences with guanosine-cytosine base specificity and may interfere with binding of transcription factors to DNA, which activates the transcription of the gene encoding ESET (a methyltransferase) [277]. The mithramycin-mediated $\mathrm{Sp} 1$ and $\mathrm{Sp} 3$ displacement downregulates ESET expression and reduces the hypertrimethylation of histone $\mathrm{H} 3$ at lysine 9 . In contrast to histone acetylation, histone methylation is associated with decreased transcriptional activity. The beneficial effects of these clinically approved antibiotics were observed in both R6/2 and N171-82Q HD mice. Mithramycin and chromomycin shift the balance from methylation to acetylation of histone $\mathrm{H} 3$ (K9), rescue the downregulation of the subset of affected genes, and improve locomotor and neuropathological phenotypes [277-279].

Another broad transcription regulator, lithium, affects a wide range of cellular functions, for example, it increases the levels of anti-apoptotic factors and affects the PKC and Wnt (through GSK3 inhibition) signaling pathways [280-282]. Zoghbi's group has shown that lithium carbonate mitigates some motor, neuropathological, and cognitive dysfunctions in 154Q knock-in mouse model of SCA1 [283]. In R6/2 HD mice, lithium treatment is associated with improvements in motor function; however, those effects have not been linked to transcriptional rescue [284].

\section{Other Therapeutic Strategies}

Mouse models of polyglutamine diseases have also been used to test therapeutic strategies that do not directly correspond to the categories described above. These other therapeutic strategies include targeting the diabetes that is present in HD mouse models, modulating transglutaminase activity, 
Table 6 Therapeutic approaches using HDAC inhibitors in mouse models of polyQ diseases

\begin{tabular}{|c|c|c|c|c|c|}
\hline Drug & Route/dose & Model & & Therapeutic outcomes & Reference \\
\hline HDACi 4b & $\begin{array}{l}1 \mathrm{~g} / \mathrm{L} \text { in drinking water, } \\
(\sim 150 \mathrm{mg} / \mathrm{kg} / \text { day })\end{array}$ & $\mathrm{R} 6 / 2^{300 \mathrm{Q}}(\mathrm{HD})$ & $\times$ & $\begin{array}{l}\text { Improved motor phenotype (rotarod performance, } \\
\text { clasping phenotype and general locomotion); } \\
\text { reduced hunchback posture; attenuated gross } \\
\text { brain size decline and striatal atrophy; attenuated } \\
\text { body weight decline } \\
\text { No change in aggregate formation }\end{array}$ & $\begin{array}{l}\text { Thomas et al. } \\
2008 \text { [276] }\end{array}$ \\
\hline Phenylbutyrate & $\begin{array}{l}\text { Intraperitoneal } \\
(100 \mathrm{mg} / \mathrm{kg} / \text { day })\end{array}$ & N171-82Q (HD) & $\begin{array}{l}\checkmark \\
\times\end{array}$ & $\begin{array}{l}\text { Prolonged life span; attenuated gross brain atrophy, } \\
\text { ventricular enlargement, and striatal neuron atrophy; } \\
\text { No change in rotarod performance and aggregate } \\
\text { formation }\end{array}$ & $\begin{array}{l}\text { Gardian et al. } \\
2005 \text { [272] }\end{array}$ \\
\hline SAHA & $\begin{array}{l}0.67 \mathrm{~g} / \mathrm{L} \text { in drinking } \\
\quad \text { water, }(\sim 100 \mathrm{mg} / \mathrm{kg} / \text { day })\end{array}$ & R6/2 (HD) & $\begin{array}{l}\checkmark \\
\times\end{array}$ & $\begin{array}{l}\text { Improved rotarod performance; attenuated neuronal } \\
\text { atrophy } \\
\text { No change in grip strength, gross brain atrophy, } \\
\text { and aggregate formation; increased body weight } \\
\text { loss rate }\end{array}$ & $\begin{array}{r}\text { Hockly et al. } \\
2003 \text { [275] }\end{array}$ \\
\hline SAHA & $\begin{array}{l}0.67 \mathrm{mg} / \mathrm{mL} \text { in drinking } \\
\text { water }(\sim 100 \mathrm{mg} / \mathrm{kg} / \text { day })\end{array}$ & R6/2 (HD) & $\checkmark$ & $\begin{array}{l}\text { Decreased HDAC } 2 \text { and } 4 \text { protein levels; } \\
\text { decreased HDAC } 7 \text { and } 11 \text { mRNA levels; restored } \\
\text { cortical BDNF mRNA level; reduced cortical } \\
\text { aggregate load }\end{array}$ & $\begin{array}{l}\text { Mielcarek et al. } \\
2011 \text { [397] }\end{array}$ \\
\hline Sodium butyrate & $\begin{array}{l}4 \text { and } 8 \mathrm{~g} / \mathrm{L} \text { in drinking } \\
\text { water }(\sim 800-900 \mathrm{mg} / \\
\mathrm{kg} / \text { day })\end{array}$ & AR-97Q (SBMA) & $\begin{array}{l}\checkmark \\
\times\end{array}$ & $\begin{array}{l}\text { Improved motor phenotype (rotarod, cage activity, } \\
\text { gait pattern); ameliorated muscle atrophy and body } \\
\text { posture; decreased body weight loss rate; prolonged } \\
\text { life span; improved motor neurons and muscle cells } \\
\text { morphology } \\
\text { No change in aggregate formation and nuclear } \\
\text { localization of mutant AR; higher doses ( } 16 \text { and } \\
40 \mathrm{~g} / \mathrm{L} \text { ) accelerated the disease onset }\end{array}$ & $\begin{array}{l}\text { Minamiyama } \\
\text { et al. } 2004 \\
\text { [270] }\end{array}$ \\
\hline Sodium butyrate & $\begin{array}{l}\text { Intraperitoneal (400 or } \\
800 \mathrm{mg} / \mathrm{kg} / \text { day) }\end{array}$ & $\begin{array}{l}\text { Ataxin-3-Q79 } \\
\quad(\mathrm{SCA} 3)\end{array}$ & $\checkmark$ & $\begin{array}{l}\text { Improved rotarod phenotype and gait pattern; reversed } \\
\text { reduction of locomotor activity; improved Purkinje } \\
\text { cell morphology; decreased body weight loss rate; } \\
\text { prolonged life span; reduced pelvic elevation and } \\
\text { abnormal hunchback posture }\end{array}$ & $\begin{array}{l}\text { Chou et al. } \\
2011 \text { [269] }\end{array}$ \\
\hline Sodium butyrate & $\begin{array}{l}\text { Intraperitoneal ( } 0.5 \text { and } \\
1.5 \mathrm{mg} / \mathrm{kg} / \text { day })\end{array}$ & $\begin{array}{l}\text { Atro } 118 Q \\
\text { (DRPLA) }\end{array}$ & $\begin{array}{l}\checkmark \\
\times\end{array}$ & $\begin{array}{l}\text { Improved motor phenotype (rotarod and grip strength); } \\
\text { prolonged life span } \\
\text { No change in aggregate formation and nuclear } \\
\text { localization of mutant atrophin; no change in somal } \\
\text { size of neurons in dentate cerebellar nucleus }\end{array}$ & $\begin{array}{l}\text { Ying et al. } \\
2006[271]\end{array}$ \\
\hline Sodium butyrate & $\begin{array}{l}\text { Intraperitoneal ( } 200,400, \\
\quad 600,1,200 \mathrm{mg} / \mathrm{kg} / \text { day })\end{array}$ & R6/2 (HD) & $\begin{array}{l}\checkmark \\
\times\end{array}$ & $\begin{array}{l}\text { Prolonged life span; improved rotarod performance; } \\
\text { increased brain weight; attenuated gross brain atrophy; } \\
\text { reduced striatal neuron atrophy } \\
\text { No treatment related reduction of body weight loss; no } \\
\text { significant reduction in huntingtin-positive striatal } \\
\text { aggregates }\end{array}$ & $\begin{array}{l}\text { Ferrante et al. } \\
2003[274]\end{array}$ \\
\hline Sodium valproate & $\begin{array}{l}\text { Intraperitoneal } \\
(100 \mathrm{mg} / \mathrm{kg} / \text { day })\end{array}$ & N171-82Q (HD) & $\begin{array}{l}\checkmark \\
\times\end{array}$ & $\begin{array}{l}\text { Prolonged life span; improved open field activity } \\
\text { No changes in the striatal dopamine, DOPAC, or } \\
\text { HVA levels }\end{array}$ & $\begin{array}{l}\text { Zádori et al. } \\
2009 \text { [273] }\end{array}$ \\
\hline
\end{tabular}

interfering with testosterone levels, and activity in SBMA models and regulating sleep/wake cycles. The DNA vaccination against the mutant protein was used in R6/2 HD model, and the overexpression of ataxin-11 (a paralog of ataxin-1) was used to enhance aggregate formation in the SCA1 154/2 model [285, 286]. Using Cox inhibitors to target inflammatory pathways has no beneficial and some deleterious effects on the pathogenesis of $\mathrm{HD}$ in R6/2 and N171-82Q mice [28, 287].

\section{Anti-diabetic Treatment}

Diabetes is present in the pathology of HD patients, and elevated levels of blood and urine glucose develop in some but not all animals in the R6/2, R6/1, $\operatorname{Hdh}(\mathrm{CAG}) 150$, and N171-82Q models [111, 288-290]. Hypoglycemic agents, such as glibenclamide and rosiglitazone, are not effective for treating diabetes in R6/2 mice [291]. The administration of insulin decreases blood glucose levels in mice, but it can be 
deleterious to them and may impair their survival, which indicates that these animals have dramatic insulin resistance. In humans and in most models of type 2 diabetes, exercise is considered beneficial for health and lifespan [292]. However, intensive physical exercise, such as excessive behavioral testing, may evoke an earlier onset of diabetes and decrease survival in R6/2 mice [291]. Insulin resistance is only partially ameliorated in male R6/2 mice by metformin and is not ameliorated in female R6/2 mice [293]. Exendin-4, the long-acting glucagon-like peptide-1 receptor agonist, ameliorates high blood glucose and improves motor phenotype in N171-82Q animals [294]. Exendin-4 can cross the bloodbrain barrier and bind to the receptors in neurons, which promotes cell survival; exendin- 4 also promotes pancreatic beta-cell growth and the production of insulin.

\section{Cystamine Treatment}

The transglutaminase inhibitor cystamine has beneficial effects in various HD mouse models such as R6/2 [295-297], YAC128 [298], and the R6/1 and Q111 knockin models [110]. Moreover, Mastroberardino and coworkers demonstrated that the genetic transglutaminase knockout has rescuing effects when combined with the R6/1 HD model [299]. Despite this body of consistent evidence for a significant role of transglutaminase in the pathogenesis of HD, the mechanism of its pathogenic contribution remains unclear. Some evidence of the mechanism was provided by examining the expression of histone $\mathrm{H} 3$ (K9) methyltransferase and observing reductions in the hypertrimethylation of $\mathrm{H} 3$ in $\mathrm{R} 6 / 2$ mice in the presence of mithramycin and cystamine. This reduction of methylation by cystamine suggested that transglutaminase 2 could be involved in HD pathogenesis by inducing transcriptional deregulation and chromatin remodeling [277]. Moreover, mithramycin, and cystamine act in an additive way, suggesting that multiple and additive mechanisms induce chromatin remodeling [277]. More direct evidence was provided recently, showing that the polyamination of the N-terminal tail of histone $\mathrm{H} 3$ by transglutaminase 2 leads to transcriptional repression of genes that are important for energy homeostasis and that are defective in HD. Moreover, the authors demonstrated that TG2 inhibition protects neurons from NMDA toxicity in YAC128 animals [300].

\section{Regulation of the Sleep/Wake Cycle}

The deregulation of the sleep-wake cycle is deleterious to cognitive function in healthy individuals and can contribute to disease progression in Huntington [301] and SCA disease patients and transgenic animals [302]. Selective loss of orexin neurons in the hippocampus of the R6/2 and SCA3 models leads to sleep disturbances and narcolepsy [303].
Sleep-wake cycles can be normalized in transgenic R6/2 animals by administering alprazolam and modafinil, which are sleep- and wake-promoting agents, respectively [304]. Interestingly, the cognitive function of HD mice improves not only after promoting regular sleep but also after promoting regular waking, with the most beneficial results reached when both drugs are used regularly [304, 305].

\section{Testosterone-Related Approaches}

Ataxin-3, huntingtin, androgen receptor, and other polyQ proteins are expressed at high levels in the testes $[60,306]$. In patients suffering from polyQ diseases, the testes are often atrophic, and the males of transgenic mouse models are sometimes infertile. SBMA is a special disease condition because the causative gene is the androgen receptor, and affected individuals are males or females who have been exposed to testosterone. The effectiveness of testosterone deprivation in SBMA therapy in mice has been confirmed by castration; administration of leuprorelin, a luteinizing hormone receptor antagonist; or by injection of a testosterone receptor antagonist [307-309]. All of these therapies ameliorate the disease phenotype or even reverse it.

In $\mathrm{HD}$, the problem is different from the problem in SBMA because the HD patients suffer from testicular atrophy thus their testosterone levels are decreased by neuroendocrine changes in hypothalamus [310]. To date, no therapeutic interventions supplementing testosterone or enhancing testosterone production in mouse models of HD have been investigated.

\section{PolyQ Mouse Models in Experimental Therapies}

PolyQ experimental therapies are almost exclusively tested in HD mouse models, which were used in tests of approximately $90 \%$ of all approaches (Fig. 8). In addition, more than $80 \%$ of all experimental polyQ therapies were tested in the R6/2, R6/1 [311], and N171-82Q [312] HD models. The remaining studies involve mouse models of SCA1, 2, 3, 7, and 17 (6.4\%); SBMA (4.8\%); and DRPLA (0.4\%). In our previous part I data table (part I of this review) which characterized the polyQ mouse models, we listed over 100 different transgenic animals and their variants. For the present therapeutic data table (Supplementary Material), we found that among nearly 250 experimental therapies, only 21 models were used (Fig. 2).

\section{HD Fragment Models}

The R6/2, R6/1, and N171-82Q are therapeutic models of choice and not always match the specific mechanisms of HD in patients. First, the rapid onset of disease phenotypes 


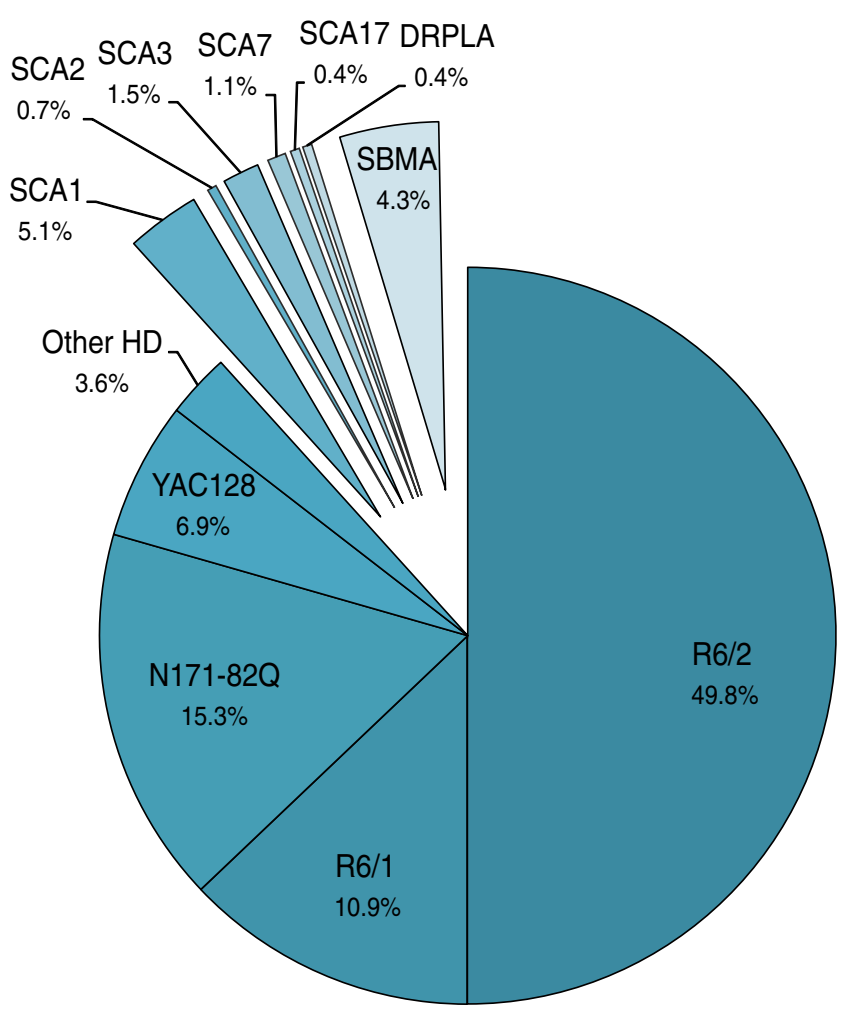

Fig. 8 The diagram demonstrates the use of various mouse models in polyglutamine disease therapeutic approaches. The vast majority of these approaches were performed on four Huntington disease models: YAC128, N171-82Q, R6/1, and R6/2. Overall, Huntington disease animals were used in studies of nearly $90 \%$ of therapeutic approaches (243 of 280). The remaining studies utilized mouse models of SBMA (11 approaches were tested in the AR97Q model and one was tested in the 112Q model), SCA1 (six approaches in the B05 and eight in the 154Q/2Q models), SCA3 (four approaches were tested in four different models-polyQ69, MJD84.2, 70.61CAG, and Q79), and SCA7 (two approaches were tested in the 90QR7E model). In addition, the SCA2 58Q, DRPLA 118Q, and Sca17 L7-hTBP models were also used for experimental therapy

observed in these models is rare in patients and is only observed in juvenile forms of HD, the disease symptoms of which differ from adult forms of HD. Second, the mutant HTT proteolysis cleavage step that initiates the pathogenesis of HD may not be required in the R6/2, R6/1, or N171-82Q models because these animals express a transgene protein that is an extremely shortened form of the native protein and that mimics the toxic cleavage fragment. N-terminal cleavage fragments were recently detected in homozygous Hdh (CAG)150 knock-in animals [313]. The putative cleavage of mutant HTT may be a limiting step and may delay pathogenesis in space (not all cell types can cleave HTT) and time (the kinetics of this process may be different in different cell types). These limitations do not exist in the R6/2, R6/1, or N171-82Q mice but may be present in patients. In addition, the behavioral phenotypes that are induced in these animals may result from dysfunction in several brain regions and types of neurons; they may also be more pronounced and less specific than in YAC128 animals. Although the R6/2, R6/1, and N171-82Q models do not imitate HD as it occurs in patients, they exhibit a low degree of variability in tested phenotypes between individual animals. This low variability influences the low standard deviation in experiments and results in a need for fewer animals to record the therapeutic outcome.

\section{HD YAC Models}

The YAC animal models (YAC128, YAC72), which have been used in 22 therapeutic approaches, contain full-length huntingtin with an expanded tract of CAG repeats [314-316]. The mild disease that appears in YAC animals result in slower experimental turnover, and the phenotypes have much greater variability than the phenotypes in R6/2. According to a power analysis performed in Hayden's laboratory, eight to 35 animals may be required to detect a $33 \%$ change in a tested phenotype, and four to 15 animals may be required to detect a $50 \%$ change in the tested phenotype following the application of a treatment [315]. Rotarod performance is highly variable in YAC128 animals, and 99 and 43 animals would be needed to detect $33 \%$ and $50 \%$ changes, respectively, when testing animals at 6 months of age [315]. These numbers contrast to R6/2 mice, where the experimental cohort can be as small as ten animals for the detection of $10 \%$ changes in some tested phenotypes [317]. Although YAC transgenic animals are not particularly convenient for testing therapeutic approaches, they recapitulate the adult pathogenesis of HD. YAC128 mice show biphasic HD disease, with initial hyperactivity and subsequent hypoactivity that is followed by brain atrophy and neuronal cell loss. Other HD animals that are used in therapeutic approaches include knock-ins containing 140 and 111 CAG repeats [318, 319], the BACHD model [320] and the EGFP HD190QG model [321].

\section{Other PolyQ Models}

Other polyQ disorders are represented by 17 therapeutic approaches in the SCA group (together with DRPLA) and 12 therapeutic approaches for SBMA. The small number of therapeutic approaches for SCA can be explained by the low prevalence of all forms of hereditary SCA, which is estimated to be four cases per 100,000, whereas HD alone could have twice as many cases $[322,323]$. Moreover, the absence of therapeutic investigations cannot simply be explained by the lack of suitable mouse models because there is a relatively broad range of choices. The models that exhibit a relatively rapid and broad phenotype include the B05 [324], SCA1 154/2 [325], SCA7 266Q/5Q [326], DRPLA Atro118Q [271], and Q129 [327] models. However, with the 
exceptions of the B05 and SCA1 154/2 models, these models are not available in commercial repositories (Jackson Laboratories), which may partially explain why they are not as widely studied.

\section{Suitability of PolyQ Mouse Models for Experimental Therapies}

There is no simple answer to the question of which model is the best suited for testing an experimental therapy. For example, would N171-82Q animals that have truncated gene, artificial promoter, and with a significantly reduced lifespan (a good therapeutic marker) be more useful than knock-in mice that are etiologically more similar to human HD but that exhibit a mild and relatively slow phenotype? Do the hyper-/hypobiphasic activity and marked cognitive deficits displayed by YAC128 mice qualify these animals as an ideal therapeutic model and eliminate the other models with phenotypes that are severe but less natural?

The concept of validity, adapted from Paul Willner's work for use in the polyQ field, can be used to identify the strengths and weaknesses of a mouse model and help answer questions about its therapeutic suitability [328, 329], see also part I of this review). According to Willner, three main validation criteria can be used to compare and describe the usefulness of any given mouse model: construct validity, face validity, and predictive validity. Although the original idea and the definitions of different forms of validity may at first sound complicated, the concept is quite intuitive $[4,330]$.

The construct validity of genetically engineered models may be understood as the degree of etiological similarity between polyQ animals and the human condition. The major feature of the polyQ disease etiology is the underlying mutation represented by CAG repeats encoding the glutamine stretches in polyQ models. Almost all models express an elongated polyglutamine stretch in various genes, but the variable length of this stretch also contributes to variable degrees of construct validities with respect to different disorders. However, there are several other differences between models contributing to the degree of construct validity. For example, the construct validity of the N171-82Q model is reduced because it utilizes a nonnative promoter that drives the expression of truncated protein, whereas the expression of full-length human huntingtin driven by native promoter and regulatory sequences in YAC128 animals gives them a higher score in terms of construct validity. Obviously, criteria for such validation are rather subjective (see part I of this review). How, then, does the construct validity impact the therapeutic suitability of polyQ models? First, it affects the severity of the phenotype in mice. Truncated models seem to produce aggressive phenotypes, some aspects of which may not be induced by molecular mechanisms that are related to a particular disease but may instead be the effect of general polyglutamine toxicity. Second, the lack of some gene or protein sequences precludes selected polyQ models from being useful for testing certain therapeutic strategies. For example, all R6 models or N171-82 animals cannot be used to test the in vivo efficacy of RNAi reagents targeting $3^{\prime}$ region of HTT mRNA or to test the use of intrabodies that are specific to the C-terminus of human huntingtin, simply because these mice do not have the sequence (target) of interest.

The face validity of mouse models is the degree of similarity between the disease phenotype observed in mice and the pathophysiology and symptomatology that occur in patients. Mice differ from humans in their genetic, physiological, and anatomical features, which may significantly influence the disease presentation. The use of mice to mirror human disorders has inherent inaccuracies and is only a rough approximation of naturally existing conditions. The open question is whether the significant differences that are observed between models with high and low degree of face validity can be considered therapeutically or biologically relevant in light of a much greater distance between model animals and patients. Nevertheless, it seems that models that are genetically closer to humans (models that possess higher construct validity) also possess a more accurate phenotype (higher face validity), which is rather slow and mild. Unfortunately, using such animals slows down the data collection and publication processes and is one of the reasons why the vast majority of therapeutic approaches are tested using animals that display severe phenotypes that are manifested early, such as the R6/2, R6/1, and N171-82Q mice (Fig. 8). Furthermore, both the severity of phenotypes and the time at which they occur during the course of disease are related to the disease penetrance, and consequently, they are related to the degree of variation between individual animals. A slow disease progression raises the possibility that small phenotypic differences caused by external sources (e.g., housing conditions) accumulate and eventually amplify undesirable phenotypic variability. In contrast, the reduced lifespan observed in "fast models" may narrow the breeding window to a period of as short as 34 weeks in R6/2 males. In addition, severe phenotypes, which weaken the animals' overall health, may lead to infertility and problems with gestation. Thus, these models tend to be more problematic in terms of breeding and maintenance (Tables 7 and 8). Overall, the suitability of polyQ mouse models for testing a preclinical therapy with respect to their face validity is not straightforward; sometimes, strong markers of the therapeutic outcome (such as an extremely shortened lifespan) are desirable even at the expense of their face validity. 
Table 7 Summarizes the suitability of the mouse models of HD for the evaluation of experimental therapies

\begin{tabular}{|c|c|c|c|c|c|c|c|c|c|}
\hline & N171-82Q & $\mathrm{R} 6 / 1$ & $\mathrm{R} 6 / 2$ & YAC128 & YAC72 & CAG140 & Q111 & BACHD & HD190QG \\
\hline $\begin{array}{l}\text { Construct validity-genetic similarity to the } \\
\text { human patients (full-length protein/natural } \\
\text { promoter/targeted transgene integration) }\end{array}$ & $-1-1-$ & $-/+/-$ & $-/+/-$ & $+{ }^{\mathrm{h}} /+/-$ & $+{ }^{\mathrm{h}} /+1-$ & $+{ }^{\mathrm{hb}} /+/+$ & $+{ }^{\mathrm{hb}} /+/+$ & $+{ }^{\mathrm{h}} /+1-$ & $-/+/-$ \\
\hline $\begin{array}{l}\text { Face validity-phenotypic similarity to the } \\
\text { human patients (specific cell loss/rotarod } \\
\text { impairment/ cognitive alterations) }\end{array}$ & $+/+/-$ & $-/+/+$ & $-/+/+$ & $+/+/+$ & $-1+/-$ & $+/+/+$ & $-1+1-$ & $-1+1-$ & $-1-1-$ \\
\hline Number of therapeutic approaches published & 42 & 30 & 139 & 21 & 1 & 1 & 1 & 5 & 2 \\
\hline Number of phenotypes identified & 64 & 71 & 170 & 51 & 12 & 44 & 15 & 23 & 11 \\
\hline $\begin{array}{l}\text { Phenotype progression (AD50; age at } 50 \% \\
\text { detected phenotypes) }\end{array}$ & 13 & 16 & 8 & 35 & 41 & 30 & 66 & 17 & 8 \\
\hline $\begin{array}{l}\text { Breeding and husbandry (severe phenotype/ } \\
\text { reduced fertility) }\end{array}$ & $+/ \mathrm{nr}$ & $\mathrm{nr}$ & $+/+$ & $\mathrm{nr}$ & $\mathrm{nr}$ & $\mathrm{nr}$ & $\mathrm{nr}$ & $\mathrm{nr}$ & $+/ \mathrm{nr}$ \\
\hline
\end{tabular}

This suitability can be evaluated by using construct validity (genetic similarities), face validity (phenotypic similarities), and predictive validity (cannot be determined at present). Moreover, this suitability can be assessed by the number of therapeutic approaches published (based on the data table) and the number of phenotypes identified (based on the data table in part I of the review). Additionally, the AD50 parameter (expressed as the number of weeks) reflects the disease dynamic in the models (see review part I for detailed information). The separate issue in assessing the therapeutic suitability in mouse models is the model maintenance and breeding

$h$ human sequence, $h b$ hybrid human/mouse sequence, $n r$ not reported, ret 90Q R7E phenotype is limited to the eye retina

If we assume that instead of assessing the absolute face validity of a given model we can evaluate the validity of certain aspects of its phenotype, then the important question becomes one of determining which model best reflects the particular phenotypes that can be used as the indicators of the therapy outcome. For phenotypes that were the most often analyzed in therapeutic approaches using mouse models of polyQ disease see Fig. S1. Table 9 shows the frequencies of the individual phenotypes that were analyzed in the four HD mouse models that are most extensively used in studies of polyQ therapy: R6/ 2, N171-82Q, R6/1, and YAC128. How frequently a certain phenotype is tested tells about its detectability in the model and its usefulness as a potent marker of a therapeutic intervention. Rotarod analyses are commonly conducted in all four models revealing that the balance and coordination impairment are strongly reflected in all of these animals. Rotarod performance is used as a phenotypic improvement marker in studies of 66$79 \%$ of all therapeutic approaches.

Although an interpretation of the frequency with which various phenotypes are studied in YAC128 mice may be imprecise because of the small number of therapeutic approaches (only 21), some general trends may be observed. In contrast to R6/2 and N171-82 mice, the YAC128 model does not allow us to interpret therapy effectiveness by studying the survival rate or body weight losses. On the other hand, the YAC128 model is more suitable for testing the impact of the evaluated therapeutics on learning deficits and neuronal cell loss. Interestingly, the neuronal cell loss is used as an indicator of therapeutic effectiveness only in seven out of 120 therapeutic approaches in R6/2 animals that were collected in the data table, which indirectly indicates a lack of cell loss in R6/2 model (Table 9).
When discussing the suitability of mouse models for preclinical therapy, the most relevant among Willner's criteria is probably that of predictive validity. This form of validity can be used to describe how well a test predicts future performance. For the purpose of analyzing the therapeutic usefulness of a mouse model, this question can be changed to: is the model capable of predicting the efficacy of a therapeutic intervention in human trials? Answering this question is not trivial; to validate a mouse model according to its predictive abilities, it is necessary to compare the outcomes of therapeutic interventions between the model and humans. Unfortunately, whereas numerous preclinical trials have been conducted in polyQ mouse models, only a few clinical trials have been conducted in patients [331]. Moreover, because there may be differences between mice and humans in both the optimal doses and pharmacokinetics of various therapeutic agents, the comparison and interpretation of study results may be difficult. Nevertheless, our data table, which lists the therapeutic outcomes of over 250 preclinical trials, may be used as a basis for the assessment of the predictive validities of polyQ mouse models as soon as more information about human trials is published.

\section{Conclusions}

The past two decades of intensive study of polyQ diseases have revealed the genetic background of these diseases, uncovered many aspects of their pathogenesis, and have brought forth a broad spectrum of animal 
Table 9 Phenotypes commonly used as therapeutic outcome indicators

\begin{tabular}{lllll}
\hline & N171-82Q & R6/1 & R6/2 & YAC 128 \\
\hline Brain atrophy & $39 \%$ & $22 \%$ & $39 \%$ & $\mathbf{6 3} \%$ \\
Cell loss & $20 \%$ & $7 \%$ & $4 \%$ & $\mathbf{5 8} \%$ \\
PolyQ aggregates & $48 \%$ & $40 \%$ & $\mathbf{5 4} \%$ & $26 \%$ \\
Brain weight & $5 \%$ & $30 \%$ & $17 \%$ & $37 \%$ \\
Rotarod test & $\mathbf{7 8} \%$ & $\mathbf{6 6} \%$ & $\mathbf{6 9} \%$ & $\mathbf{7 9} \%$ \\
Stride abnormalities & $22 \%$ & $18 \%$ & $20 \%$ & $32 \%$ \\
Locomotor impairment & $10 \%$ & $19 \%$ & $32 \%$ & $26 \%$ \\
Grip strength & $7 \%$ & $4 \%$ & $13 \%$ & $5 \%$ \\
Clasping & $10 \%$ & $40 \%$ & $24 \%$ & $16 \%$ \\
Learning deficits & $2 \%$ & $15 \%$ & $13 \%$ & $26 \%$ \\
Premature death & $\mathbf{8 5} \%$ & $4 \%$ & $\mathbf{7 0} \%$ & $0 \%$ \\
Body weight loss & $\mathbf{7 1} \%$ & $\mathbf{6 3} \%$ & $\mathbf{7 6} \%$ & $12 \%$ \\
\hline
\end{tabular}

Table 9 demonstrates how frequently a certain phenotype is tested to reveal the therapeutic outcome. This indirectly indicates the detectability and usefulness of a given phenotype in mice as a potent marker of a therapeutic intervention. Note that when a particular phenotype was tested in an individual therapeutic approach several times (e.g., using different methods), it was counted in the table only once. Phenotypes that were frequently selected as therapeutic intervention markers (in more than $50 \%$ of the approaches) are marked in bold

models. Unfortunately, an effective cure is still not available, and several intriguing questions remain unsolved. What we know is that expanded polyglutamine proteins alter many different cellular processes, which has important therapeutic implications. The pathomechanisms involved in disease development and progression are complex, independent, and often occur in parallel. Examples of such mechanisms are transcriptional deregulation, clearance machinery deficiency, and mitochondrial impairment. Therefore, a successful therapeutic approach should probably target multiple aspects of disease pathogenesis. Introducing genetic mouse models into the polyQ field has facilitated understanding of the etiologies of polyQ diseases and has accelerated the design and testing of new therapeutic approaches. In this work, we have reviewed approximately 250 therapeutic interventions that have been studied in mouse models of polyQ diseases. Our review is supported by the data table that contains over 2,000 records describing the in vivo therapeutic approaches. The data table includes detailed information about the mouse models, therapeutic strategies, methods of testing, outcomes, phenotypes used to test the outcomes, active substances, and their targets. Although the vast majority of therapeutic approaches have involved mouse models of HD, there are some common therapeutic approaches that were tested in other diseases. We believe that integrating the information about polyQ therapy in one 
framework can provide a new perspective for therapeutic research.

Therapeutic references not directly cited in text, [332-391].

Acknowledgments This work was supported by the European Regional Development Fund within the Innovative Economy Programme (grant numbers POIG.01.03.01-30-049/09 and POIG.01.03.01-30-098/ 08 ) and the grant of Polish Ministry of Science and Higher Education (grant number: N N302 299536).

Open Access This article is distributed under the terms of the Creative Commons Attribution License which permits any use, distribution, and reproduction in any medium, provided the original author(s) and the source are credited.

\section{References}

1. Durr A (2010) Autosomal dominant cerebellar ataxias: polyglutamine expansions and beyond. Lancet Neurol 9(9):885-894

2. Ross CA, Tabrizi SJ (2011) Huntington's disease: from molecular pathogenesis to clinical treatment. Lancet Neurol 10(1):83-98

3. Beal MF, Ferrante RJ (2004) Experimental therapeutics in transgenic mouse models of Huntington's disease. Nat Rev Neurosci 5 (5):373-384

4. Wagner L, Menalled L, Gomeniouk A, Brunner D, Leavitt B (2008) Huntington Disease. Animal and Translational Models for CNS Drug Discovery. Elsevier, pp 207-266

5. Bauer PO, Nukina N (2009) The pathogenic mechanisms of polyglutamine diseases and current therapeutic strategies. J Neurochem 110(6):1737-1765

6. Zuccato C, Valenza M, Cattaneo E (2010) Molecular mechanisms and potential therapeutical targets in Huntington's disease. Physiol Rev 90(3):905-981

7. Orr HT, Zoghbi HY (2007) Trinucleotide repeat disorders. Annu Rev Neurosci 30:575-621

8. Shao J, Diamond MI (2007) Polyglutamine diseases: emerging concepts in pathogenesis and therapy. Hum Mol Genet 16 Spec No. 2:R115-123

9. Nedelsky NB, Todd PK, Taylor JP (2008) Autophagy and the ubiquitin-proteasome system: collaborators in neuroprotection. Biochim Biophys Acta 1782(12):691-699

10. Bennett EJ, Shaler TA, Woodman B, Ryu K-Y, Zaitseva TS, Becker CH, Bates GP, Schulman H, Kopito RR (2007) Global changes to the ubiquitin system in Huntington's disease. Nature 448(7154):704-708

11. Martinez-Vicente M, Talloczy Z, Wong E et al (2010) Cargo recognition failure is responsible for inefficient autophagy in Huntington's disease. Nat Neurosci 13(5):567-576

12. Heng MY, Duong DK, Albin RL, Tallaksen-Greene SJ, Hunter JM, Lesort MJ, Osmand A, Paulson HL, Detloff PJ (2010) Early autophagic response in a novel knock-in model of Huntington disease. Hum Mol Genet 19(19):3702-3720

13. Ortega Z, Díaz-Hernández M, Maynard CJ, Hernández F, Dantuma NP, Lucas JJ (2010) Acute polyglutamine expression in inducible mouse model unravels ubiquitin/proteasome system impairment and permanent recovery attributable to aggregate formation. J Neurosci 30(10):3675-3688

14. Rubinsztein DC (2006) The roles of intracellular protein-degradation pathways in neurodegeneration. Nature 443(7113):780-786

15. Wong E, Cuervo AM (2010) Integration of clearance mechanisms: the proteasome and autophagy. Cold Spring Harb Perspect Biol 2(12):a006734
16. Ravikumar B, Vacher C, Berger Z et al (2004) Inhibition of mTOR induces autophagy and reduces toxicity of polyglutamine expansions in fly and mouse models of Huntington disease. Nat Genet 36(6):585-595

17. Menzies FM, Huebener J, Renna M, Bonin M, Riess O, Rubinsztein DC (2010) Autophagy induction reduces mutant ataxin-3 levels and toxicity in a mouse model of spinocerebellar ataxia type 3 . Brain 133(Pt 1):93-104

18. Fox JH, Connor T, Chopra V et al (2010) The mTOR kinase inhibitor Everolimus decreases S6 kinase phosphorylation but fails to reduce mutant huntingtin levels in brain and is not neuroprotective in the R6/2 mouse model of Huntington's disease. Mol Neurodegener 5:26

19. Rose C, Menzies FM, Renna M, Acevedo-Arozena A, Corrochano S, Sadiq O, Brown SD, Rubinsztein DC (2010) Rilmenidine attenuates toxicity of polyglutamine expansions in a mouse model of Huntington's disease. Hum Mol Genet 19(11):2144-2153

20. Torashima T, Koyama C, Iizuka A, Mitsumura K, Takayama K, Yanagi S, Oue M, Yamaguchi H, Hirai H (2008) Lentivectormediated rescue from cerebellar ataxia in a mouse model of spinocerebellar ataxia. EMBO Rep 9(4):393-399

21. Adachi H, Waza M, Tokui K, Katsuno M, Minamiyama M, Tanaka F, Doyu M, Sobue G (2007) CHIP overexpression reduces mutant androgen receptor protein and ameliorates phenotypes of the spinal and bulbar muscular atrophy transgenic mouse model. J Neurosci 27(19):5115-5126

22. Wong HK, Bauer PO, Kurosawa M et al (2008) Blocking acidsensing ion channel 1 alleviates Huntington's disease pathology via an ubiquitin-proteasome system-dependent mechanism. Hum Mol Genet 17(20):3223-3235

23. Yamamoto A, Lucas JJ, Hen R (2000) Reversal of neuropathology and motor dysfunction in a conditional model of Huntington's disease. Cell 101(1):57-66

24. Takahashi T, Katada S, Onodera O (2010) Polyglutamine diseases: where does toxicity come from? what is toxicity? where are we going? J Mol Cell Biol 2(4):180-191

25. Nagai Y, Popiel HA (2008) Conformational changes and aggregation of expanded polyglutamine proteins as therapeutic targets of the polyglutamine diseases: exposed beta-sheet hypothesis. Curr Pharm Des 14(30):3267-3279

26. Sánchez I, Mahlke C, Yuan J (2003) Pivotal role of oligomerization in expanded polyglutamine neurodegenerative disorders. Nature 421(6921):373-379

27. Smith DL, Woodman B, Mahal A, Sathasivam K, Ghazi-Noori S, Lowden PAS, Bates GP, Hockly E (2003) Minocycline and doxycycline are not beneficial in a model of Huntington's disease. Ann Neurol 54(2):186-196

28. Schilling G, Savonenko AV, Coonfield ML et al (2004) Environmental, pharmacological, and genetic modulation of the HD phenotype in transgenic mice. Exp Neurol 187(1):137-149

29. Tanaka M, Machida Y, Niu S, Ikeda T, Jana NR, Doi H, Kurosawa M, Nekooki M, Nukina N (2004) Trehalose alleviates polyglutamine-mediated pathology in a mouse model of Huntington disease. Nat Med 10(2):148-154

30. Hockly E, Tse J, Barker AL et al (2006) Evaluation of the benzothiazole aggregation inhibitors riluzole and PGL-135 as therapeutics for Huntington's disease. Neurobiol Dis 21(1):228-236

31. Wood NI, Pallier PN, Wanderer J, Morton AJ (2007) Systemic administration of Congo red does not improve motor or cognitive function in R6/2 mice. Neurobiol Dis 25(2):342-353

32. Chopra V, Fox JH, Lieberman G, Dorsey K, Matson W, Waldmeier P, Housman DE, Kazantsev A, Young AB, Hersch S (2007) A small-molecule therapeutic lead for Huntington's disease: preclinical pharmacology and efficacy of C2-8 in the R6/2 transgenic mouse. Proc Natl Acad Sci U S A 104(42):16685-16689 
33. Yang C-R, Yu RK (2009) Intracerebral transplantation of neural stem cells combined with trehalose ingestion alleviates pathology in a mouse model of Huntington's disease. J Neurosci Res 87(1):26-33

34. Popiel HA, Nagai Y, Fujikake N, Toda T (2009) Delivery of the aggregate inhibitor peptide QBP1 into the mouse brain using PTDs and its therapeutic effect on polyglutamine disease mice. Neurosci Lett 449(2):87-92

35. Wang C-E, Zhou H, McGuire JR, Cerullo V, Lee B, Li S-H, Li X-J (2008) Suppression of neuropil aggregates and neurological symptoms by an intracellular antibody implicates the cytoplasmic toxicity of mutant huntingtin. J Cell Biol 181(5):803-816

36. Southwell AL, Ko J, Patterson PH (2009) Intrabody gene therapy ameliorates motor, cognitive, and neuropathological symptoms in multiple mouse models of Huntington's disease. J Neurosci 29 (43):13589-13602

37. Snyder-Keller A, McLear JA, Hathorn T, Messer A (2010) Early or late-stage anti-N-terminal Huntingtin intrabody gene therapy reduces pathological features in B6.HDR6/1 mice. J Neuropathol Exp Neurol 69(10):1078-1085

38. Carmichael J, Chatellier J, Woolfson A, Milstein C, Fersht AR, Rubinsztein DC (2000) Bacterial and yeast chaperones reduce both aggregate formation and cell death in mammalian cell models of Huntington's disease. Proc Natl Acad Sci U S A 97 (17):9701-9705

39. Novoselova TV, Margulis BA, Novoselov SS, Sapozhnikov AM, van der Spuy J, Cheetham ME, Guzhova IV (2005) Treatment with extracellular HSP70/HSC70 protein can reduce polyglutamine toxicity and aggregation. J Neurochem 94(3):597-606

40. McLear JA, Lebrecht D, Messer A, Wolfgang WJ (2008) Combinational approach of intrabody with enhanced Hsp70 expression addresses multiple pathologies in a fly model of Huntington's disease. FASEB J 22(6):2003-2011

41. Hansson $\mathrm{O}$, Nylandsted J, Castilho RF, Leist M, Jäättelä M, Brundin P (2003) Overexpression of heat shock protein 70 in R6/2 Huntington's disease mice has only modest effects on disease progression. Brain Res 970(1-2):47-57

42. Vacher C, Garcia-Oroz L, Rubinsztein DC (2005) Overexpression of yeast hsp104 reduces polyglutamine aggregation and prolongs survival of a transgenic mouse model of Huntington's disease. Hum Mol Genet 14(22):3425-3433

43. Orr AL, Huang S, Roberts MA, Reed JC, Li S, Li X-J (2008) Sexdependent effect of BAG1 in ameliorating motor deficits of Huntington disease transgenic mice. J Biol Chem 283(23):16027-16036

44. Hay DG, Sathasivam K, Tobaben S, Stahl B, Marber M, Mestril R, Mahal A, Smith DL, Woodman B, Bates GP (2004) Progressive decrease in chaperone protein levels in a mouse model of Huntington's disease and induction of stress proteins as a therapeutic approach. Hum Mol Genet 13(13):1389-1405

45. Fujimoto M, Takaki E, Hayashi T, Kitaura Y, Tanaka Y, Inouye S, Nakai A (2005) Active HSF1 significantly suppresses polyglutamine aggregate formation in cellular and mouse models. J Biol Chem 280(41):34908-34916

46. Cummings CJ, Sun Y, Opal P, Antalffy B, Mestril R, Orr HT, Dillmann WH, Zoghbi HY (2001) Over-expression of inducible HSP70 chaperone suppresses neuropathology and improves motor function in SCA1 mice. Hum Mol Genet 10(14):1511-1518

47. Adachi H, Katsuno M, Minamiyama M et al (2003) Heat shock protein 70 chaperone overexpression ameliorates phenotypes of the spinal and bulbar muscular atrophy transgenic mouse model by reducing nuclear-localized mutant androgen receptor protein. J Neurosci 23(6):2203-2211

48. Katsuno M, Sang C, Adachi H, Minamiyama M, Waza M, Tanaka F, Doyu M, Sobue G (2005) Pharmacological induction of heat-shock proteins alleviates polyglutamine-mediated motor neuron disease. Proc Natl Acad Sci U S A 102(46):16801-16806
49. Waza M, Adachi H, Katsuno M, Minamiyama M, Sang C, Tanaka F, Inukai A, Doyu M, Sobue G (2005) 17-AAG, an Hsp90 inhibitor, ameliorates polyglutamine-mediated motor neuron degeneration. Nat Med 11(10):1088-1095

50. Tokui K, Adachi H, Waza M et al (2009) 17-DMAG ameliorates polyglutamine-mediated motor neuron degeneration through well-preserved proteasome function in an SBMA model mouse. Hum Mol Genet 18(5):898-910

51. Jensen NM, Dalsgaard T, Jakobsen M, Nielsen RR, Sørensen CB, Bolund L, Jensen TG (2011) An update on targeted gene repair in mammalian cells: methods and mechanisms. J Biomed Sci 18:10

52. Xia H, Mao Q, Eliason SL, Harper SQ, Martins IH, Orr HT, Paulson HL, Yang L, Kotin RM, Davidson BL (2004) RNAi suppresses polyglutamine-induced neurodegeneration in a model of spinocerebellar ataxia. Nat Med 10(8):816-820

53. Harper SQ, Staber PD, He X, Eliason SL, Martins IH, Mao Q, Yang L, Kotin RM, Paulson HL, Davidson BL (2005) RNA interference improves motor and neuropathological abnormalities in a Huntington's disease mouse model. Proc Natl Acad Sci USA 102(16):5820-5825

54. Rodriguez-Lebron E, Denovan-Wright EM, Nash K, Lewin AS, Mandel RJ (2005) Intrastriatal rAAV-mediated delivery of antihuntingtin shRNAs induces partial reversal of disease progression in R6/1 Huntington's disease transgenic mice. Mol Ther 12(4):618-633

55. Wang Y-L, Liu W, Wada E, Murata M, Wada K, Kanazawa I (2005) Clinico-pathological rescue of a model mouse of Huntington's disease by siRNA. Neurosci Res 53(3):241-249

56. Machida Y, Okada T, Kurosawa M, Oyama F, Ozawa K, Nukina N (2006) rAAV-mediated shRNA ameliorated neuropathology in Huntington disease model mouse. Biochem Biophys Res Commun 343(1):190-197

57. Boudreau RL, McBride JL, Martins I, Shen S, Xing Y, Carter BJ, Davidson BL (2009) Nonallele-specific silencing of mutant and wild-type huntingtin demonstrates therapeutic efficacy in Huntington's disease mice. Mol Ther 17(6):1053-1063

58. Drouet V, Perrin V, Hassig R et al (2009) Sustained effects of nonallele-specific Huntingtin silencing. Ann Neurol 65(3):276-285

59. Schmitt I, Linden M, Khazneh H, Evert BO, Breuer P, Klockgether T, Wuellner U (2007) Inactivation of the mouse Atxn3 (ataxin-3) gene increases protein ubiquitination. Biochem Biophys Res Commun 362(3):734-739

60. Switonski PM, Fiszer A, Kazmierska K, Kurpisz M, Krzyzosiak WJ, Figiel M (2011) Mouse ataxin-3 functional knock-out model. Neuromolecular Med 13(1):54-65

61. Pfister EL, Kennington L, Straubhaar J, Wagh S, Liu W, DiFiglia M, Landwehrmeyer B, Vonsattel J-P, Zamore PD, Aronin N (2009) Five siRNAs targeting three SNPs may provide therapy for three-quarters of Huntington's disease patients. Curr Biol 19 (9):774-778

62. Miller VM, Xia H, Marrs GL, Gouvion CM, Lee G, Davidson BL, Paulson HL (2003) Allele-specific silencing of dominant disease genes. Proc Natl Acad Sci U S A 100(12):7195-7200

63. Alves S, Nascimento-Ferreira I, Auregan G, Hassig R, Dufour N, Brouillet E, Pedroso de Lima MC, Hantraye P, Pereira de Almeida L, Déglon N (2008) Allele-specific RNA silencing of mutant ataxin-3 mediates neuroprotection in a rat model of Machado-Joseph disease. PLoS One 3(10):e3341

64. Fiszer A, Mykowska A, Krzyzosiak WJ (2011) Inhibition of mutant huntingtin expression by RNA duplex targeting expanded CAG repeats. Nucleic Acids Res 39(13):5578-85

65. Hu J, Matsui M, Gagnon KT, Schwartz JC, Gabillet S, Arar K, Wu J, Bezprozvanny I, Corey DR (2009) Allele-specific silencing of mutant huntingtin and ataxin-3 genes by targeting expanded CAG repeats in mRNAs. Nat Biotechnol 27(5): $478-484$ 
66. Hu J, Liu J, Corey DR (2010) Allele-selective inhibition of huntingtin expression by switching to an miRNA-like RNAi mechanism. Chem Biol 17(11):1183-1188

67. Wojciechowska M, Krzyzosiak WJ (2011) Cellular toxicity of expanded RNA repeats: focus on RNA foci. Hum Mol Genet 20 (19):3811-3821

68. Krzyzosiak WJ, Sobczak K, Wojciechowska M, Fiszer A, Mykowska A, Kozlowski P (2012) Triplet repeat RNA structure and its role as pathogenic agent and therapeutic target. Nucleic Acids Res 40(1):11-26

69. Rangasamy SB, Soderstrom K, Bakay RAE, Kordower JH (2010) Neurotrophic factor therapy for Parkinson's disease. Prog Brain Res 184:237-264

70. Nagahara AH, Tuszynski MH (2011) Potential therapeutic uses of BDNF in neurological and psychiatric disorders. Nat Rev Drug Discov 10(3):209-219

71. Pascual A, Hidalgo-Figueroa M, Piruat JI, Pintado CO, GómezDíaz R, López-Barneo J (2008) Absolute requirement of GDNF for adult catecholaminergic neuron survival. Nat Neurosci 11 (7):755-761

72. Choi J-S, Kim SY, Park H-J, Cha J-H, Choi Y-S, Chung J-W, Chun M-H, Lee M-Y (2004) Differential regulation of ciliary neurotrophic factor and its receptor in the rat hippocampus in response to kainic acid-induced excitotoxicity. Mol Cells 17(2):292-296

73. Royo NC, Conte V, Saatman KE, Shimizu S, Belfield CM, Soltesz KM, Davis JE, Fujimoto ST, McIntosh TK (2006) Hippocampal vulnerability following traumatic brain injury: a potential role for neurotrophin-4/5 in pyramidal cell neuroprotection. Eur J Neurosci 23(5):1089-1102

74. Ramaswamy S, Soderstrom KE, Kordower JH (2009) Trophic factors therapy in Parkinson's disease. Prog Brain Res 175:201-216

75. Zuccato C, Cattaneo E (2009) Brain-derived neurotrophic factor in neurodegenerative diseases. Nat Rev Neurol 5(6):311-322

76. Zuccato C, Ciammola A, Rigamonti D et al (2001) Loss of huntingtin-mediated BDNF gene transcription in Huntington's disease. Science 293(5529):493-498

77. Zuccato C, Liber D, Ramos C, Tarditi A, Rigamonti D, Tartari M, Valenza M, Cattaneo E (2005) Progressive loss of BDNF in a mouse model of Huntington's disease and rescue by BDNF delivery. Pharmacol Res 52(2):133-139

78. Gauthier LR, Charrin BC, Borrell-Pagès M et al (2004) Huntingtin controls neurotrophic support and survival of neurons by enhancing BDNF vesicular transport along microtubules. Cell 118(1):127-138

79. Zuccato C, Tartari M, Crotti A et al (2003) Huntingtin interacts with REST/NRSF to modulate the transcription of NRSEcontrolled neuronal genes. Nat Genet 35(1):76-83

80. Canals JM, Pineda JR, Torres-Peraza JF, Bosch M, Martín-Ibañez R, Muñoz MT, Mengod G, Ernfors P, Alberch J (2004) Brainderived neurotrophic factor regulates the onset and severity of motor dysfunction associated with enkephalinergic neuronal degeneration in Huntington's disease. J Neurosci 24(35):7727-7739

81. Pineda JR, Canals JM, Bosch M, Adell A, Mengod G, Artigas F, Ernfors P, Alberch J (2005) Brain-derived neurotrophic factor modulates dopaminergic deficits in a transgenic mouse model of Huntington's disease. J Neurochem 93(5):1057-1068

82. Giralt A, Rodrigo T, Martín ED, Gonzalez JR, Milà M, Ceña V, Dierssen M, Canals JM, Alberch J (2009) Brain-derived neurotrophic factor modulates the severity of cognitive alterations induced by mutant huntingtin: involvement of phospholipaseCgamma activity and glutamate receptor expression. Neuroscience 158(4):1234 1250

83. Bemelmans AP, Horellou P, Pradier L, Brunet I, Colin P, Mallet J (1999) Brain-derived neurotrophic factor-mediated protection of striatal neurons in an excitotoxic rat model of Huntington's disease, as demonstrated by adenoviral gene transfer. Hum Gene Ther 10(18):2987-2997

84. de Almeida LP, Zala D, Aebischer P, Déglon N (2001) Neuroprotective effect of a CNTF-expressing lentiviral vector in the quinolinic acid rat model of Huntington's disease. Neurobiol Dis 8(3):433-446

85. Pérez-Navarro E, Canudas AM, Akerund P, Alberch J, Arenas E (2000) Brain-derived neurotrophic factor, neurotrophin-3, and neurotrophin- $4 / 5$ prevent the death of striatal projection neurons in a rodent model of Huntington's disease. J Neurochem 75(5):2190-2199

86. Gharami K, Xie Y, An JJ, Tonegawa S, Xu B (2008) Brainderived neurotrophic factor over-expression in the forebrain ameliorates Huntington's disease phenotypes in mice. J Neurochem 105(2):369-379

87. Xie Y, Hayden MR, Xu B (2010) BDNF overexpression in the forebrain rescues Huntington's disease phenotypes in YAC128 mice. J Neurosci 30(44):14708-14718

88. Cho S-R, Benraiss A, Chmielnicki E, Samdani A, Economides A, Goldman SA (2007) Induction of neostriatal neurogenesis slows disease progression in a transgenic murine model of Huntington disease. J Clin Invest 117(10):2889-2902

89. McBride JL, Ramaswamy S, Gasmi M, Bartus RT, Herzog CD, Brandon EP, Zhou L, Pitzer MR, Berry-Kravis EM, Kordower JH (2006) Viral delivery of glial cell line-derived neurotrophic factor improves behavior and protects striatal neurons in a mouse model of Huntington's disease. Proc Natl Acad Sci U S A 103(24):9345-9350

90. Ramaswamy S, McBride JL, Han I, Berry-Kravis EM, Zhou L, Herzog CD, Gasmi M, Bartus RT, Kordower JH (2009) Intrastriatal CERE-120 (AAV-Neurturin) protects striatal and cortical neurons and delays motor deficits in a transgenic mouse model of Huntington's disease. Neurobiol Dis 34(1):40-50

91. Dey ND, Bombard MC, Roland BP, Davidson S, Lu M, Rossignol J, Sandstrom MI, Skeel RL, Lescaudron L, Dunbar GL (2010) Genetically engineered mesenchymal stem cells reduce behavioral deficits in the YAC 128 mouse model of Huntington's disease. Behav Brain Res 214(2):193-200

92. Jin K, LaFevre-Bernt M, Sun Y, Chen S, Gafni J, Crippen D, Logvinova A, Ross CA, Greenberg DA, Ellerby LM (2005) FGF2 promotes neurogenesis and neuroprotection and prolongs survival in a transgenic mouse model of Huntington's disease. Proc Natl Acad Sci USA 102(50):18189-18194

93. Zala D, Bensadoun J-C, Pereira de Almeida L, Leavitt BR, Gutekunst C-A, Aebischer P, Hayden MR, Déglon N (2004) Long-term lentiviral-mediated expression of ciliary neurotrophic factor in the striatum of Huntington's disease transgenic mice. Exp Neurol 185(1):26-35

94. Denovan-Wright EM, Attis M, Rodriguez-Lebron E, Mandel RJ (2008) Sustained striatal ciliary neurotrophic factor expression negatively affects behavior and gene expression in normal and R6/1 mice. J Neurosci Res 86(8):1748-1757

95. Duan W, Guo Z, Jiang H, Ladenheim B, Xu X, Cadet JL, Mattson MP (2004) Paroxetine retards disease onset and progression in Huntingtin mutant mice. Ann Neurol 55(4):590-594

96. Duan W, Peng Q, Masuda N, Ford E, Tryggestad E, Ladenheim B, Zhao M, Cadet JL, Wong J, Ross CA (2008) Sertraline slows disease progression and increases neurogenesis in N171-82Q mouse model of Huntington's disease. Neurobiol Dis 30(3):312-322

97. Grote HE, Bull ND, Howard ML, van Dellen A, Blakemore C, Bartlett PF, Hannan AJ (2005) Cognitive disorders and neurogenesis deficits in Huntington's disease mice are rescued by fluoxetine. Eur J Neurosci 22(8):2081-2088

98. Cheng Y, Peng Q, Hou Z, Aggarwal M, Zhang J, Mori S, Ross CA, Duan W (2011) Structural MRI detects progressive regional brain atrophy and neuroprotective effects in N171-82Q Huntington's disease mouse model. NeuroImage 56(3):1027-1034 
99. Peng Q, Masuda N, Jiang M, Li Q, Zhao M, Ross CA, Duan W (2008) The antidepressant sertraline improves the phenotype, promotes neurogenesis and increases BDNF levels in the R6/2 Huntington's disease mouse model. Exp Neurol 210(1):154-163

100. Martinowich K, Lu B (2008) Interaction between BDNF and serotonin: role in mood disorders. Neuropsychopharmacology 33(1):73-83

101. Simmons DA, Rex CS, Palmer L, Pandyarajan V, Fedulov V, Gall CM, Lynch G (2009) Up-regulating BDNF with an ampakine rescues synaptic plasticity and memory in Huntington's disease knockin mice. Proc Natl Acad Sci U S A 106(12):4906-4911

102. Simmons DA, Mehta RA, Lauterborn JC, Gall CM, Lynch G (2011) Brief ampakine treatments slow the progression of Huntington's disease phenotypes in R6/2 mice. Neurobiol Dis 41(2):436-444

103. Apostol BL, Simmons DA, Zuccato C et al (2008) CEP-1347 reduces mutant huntingtin-associated neurotoxicity and restores BDNF levels in R6/2 mice. Mol Cell Neurosci 39(1):8-20

104. DeMarch Z, Giampà C, Patassini S, Bernardi G, Fusco FR (2008) Beneficial effects of rolipram in the R6/2 mouse model of Huntington's disease. Neurobiol Dis 30(3):375-387

105. Giampà $\mathrm{C}$, Laurenti $\mathrm{D}$, Anzilotti $\mathrm{S}$, Bernardi G, Menniti FS, Fusco FR (2010) Inhibition of the striatal specific phosphodiesterase PDE10A ameliorates striatal and cortical pathology in R6/2 mouse model of Huntington's disease. PLoS One 5(10):e13417

106. Cho KJ, Lee BI, Cheon SY, Kim HW, Kim HJ, Kim GW (2009) Inhibition of apoptosis signal-regulating kinase 1 reduces endoplasmic reticulum stress and nuclear huntingtin fragments in a mouse model of Huntington disease. Neuroscience 163(4):1128-1134

107. Saydoff JA, Garcia RAG, Browne SE et al (2006) Oral uridine prodrug PN401 is neuroprotective in the R6/2 and N171-82Q mouse models of Huntington's disease. Neurobiol Dis 24(3):455-465

108. Hathorn T, Snyder-Keller A, Messer A (2011) Nicotinamide improves motor deficits and upregulates PGC- $1 \alpha$ and BDNF gene expression in a mouse model of Huntington's disease. Neurobiol Dis 41(1):43-50

109. Chiang M-C, Chen C-M, Lee M-R et al (2010) Modulation of energy deficiency in Huntington's disease via activation of the peroxisome proliferator-activated receptor gamma. Hum Mol Genet 19(20):4043-4058

110. Borrell-Pagès M, Canals JM, Cordelières FP et al (2006) Cystamine and cysteamine increase brain levels of BDNF in Huntington disease via HSJ1b and transglutaminase. J Clin Invest 116(5):1410-1424

111. Duan W, Guo Z, Jiang H, Ware M, Li X-J, Mattson MP (2003) Dietary restriction normalizes glucose metabolism and BDNF levels, slows disease progression, and increases survival in huntingtin mutant mice. Proc Natl Acad Sci U S A 100(5):2911-2916

112. Fumagalli E, Bigini P, Barbera S, De Paola M, Mennini T (2006) Riluzole, unlike the AMPA antagonist RPR119990, reduces motor impairment and partially prevents motoneuron death in the wobbler mouse, a model of neurodegenerative disease. Exp Neurol 198(1):114-128

113. Meisner F, Scheller C, Kneitz S, Sopper S, Neuen-Jacob E, Riederer P, ter Meulen V, Koutsilieri E (2008) Memantine upregulates BDNF and prevents dopamine deficits in SIV-infected macaques: a novel pharmacological action of memantine. Neuropsychopharmacology 33(9):2228-2236

114. Greer PL, Greenberg ME (2008) From synapse to nucleus: calcium-dependent gene transcription in the control of synapse development and function. Neuron 59(6):846-860

115. Zuccato C, Cattaneo E (2007) Role of brain-derived neurotrophic factor in Huntington's disease. Prog Neurobiol 81(5-6):294-330

116. van Praag H, Kempermann G, Gage FH (2000) Neural consequences of environmental enrichment. Nat Rev Neurosci 1(3):191-198
117. van Dellen A, Blakemore C, Deacon R, York D, Hannan AJ (2000) Delaying the onset of Huntington's in mice. Nature 404 (6779):721-722

118. Carter RJ, Hunt MJ, Morton AJ (2000) Environmental stimulation increases survival in mice transgenic for exon 1 of the Huntington's disease gene. Mov Disord 15(5):925-937

119. Hockly E, Cordery PM, Woodman B, Mahal A, van Dellen A, Blakemore C, Lewis CM, Hannan AJ, Bates GP (2002) Environmental enrichment slows disease progression in R6/2 Huntington's disease mice. Ann Neurol 51(2):235-242

120. Glass M, van Dellen A, Blakemore C, Hannan AJ, Faull RLM (2004) Delayed onset of Huntington's disease in mice in an enriched environment correlates with delayed loss of cannabinoid CB1 receptors. Neuroscience 123(1):207-212

121. Spires TL, Grote HE, Varshney NK, Cordery PM, van Dellen A, Blakemore C, Hannan AJ (2004) Environmental enrichment rescues protein deficits in a mouse model of Huntington's disease, indicating a possible disease mechanism. J Neurosci 24(9):2270-2276

122. Lazic SE, Grote HE, Blakemore C, Hannan AJ, van Dellen A, Phillips W, Barker RA (2006) Neurogenesis in the R6/1 transgenic mouse model of Huntington's disease: effects of environmental enrichment. Eur J Neurosci 23(7):1829-1838

123. Pang TYC, Stam NC, Nithianantharajah J, Howard ML, Hannan AJ (2006) Differential effects of voluntary physical exercise on behavioral and brain-derived neurotrophic factor expression deficits in Huntington's disease transgenic mice. Neuroscience 141 (2):569-584

124. Nithianantharajah J, Barkus C, Murphy M, Hannan AJ (2008) Gene-environment interactions modulating cognitive function and molecular correlates of synaptic plasticity in Huntington's disease transgenic mice. Neurobiol Dis 29(3):490-504

125. van Dellen A, Cordery PM, Spires TL, Blakemore C, Hannan AJ (2008) Wheel running from a juvenile age delays onset of specific motor deficits but does not alter protein aggregate density in a mouse model of Huntington's disease. BMC Neurosci 9:34

126. Benn CL, Luthi-Carter R, Kuhn A et al (2010) Environmental enrichment reduces neuronal intranuclear inclusion load but has no effect on messenger RNA expression in a mouse model of Huntington disease. J Neuropathol Exp Neurol 69(8):817-827

127. Wood NI, Glynn D, Morton AJ (2011) "Brain training" improves cognitive performance and survival in a transgenic mouse model of Huntington's disease. Neurobiol Dis 42(3):427-437

128. Zajac MS, Pang TYC, Wong N, Weinrich B, Leang LSK, Craig JM, Saffery R, Hannan AJ (2010) Wheel running and environmental enrichment differentially modify exon-specific BDNF expression in the hippocampus of wild-type and pre-motor symptomatic male and female Huntington's disease mice. Hippocampus 20(5):621-636

129. Wood NI, Carta V, Milde S et al (2010) Responses to environmental enrichment differ with sex and genotype in a transgenic mouse model of Huntington's disease. PLoS One 5(2):e9077

130. Neeper SA, Gómez-Pinilla F, Choi J, Cotman CW (1996) Physical activity increases mRNA for brain-derived neurotrophic factor and nerve growth factor in rat brain. Brain Res 726(12):49-56

131. Rampon C, Jiang $\mathrm{CH}$, Dong $\mathrm{H}$, Tang YP, Lockhart DJ, Schultz PG, Tsien JZ, Hu Y (2000) Effects of environmental enrichment on gene expression in the brain. Proc Natl Acad Sci USA 97 (23):12880-12884

132. Brown J, Cooper-Kuhn CM, Kempermann G, Van Praag H, Winkler J, Gage FH, Kuhn HG (2003) Enriched environment and physical activity stimulate hippocampal but not olfactory bulb neurogenesis. Eur J Neurosci 17(10):2042-2046

133. Kohl Z, Kandasamy M, Winner B, Aigner R, Gross C, CouillardDespres S, Bogdahn U, Aigner L, Winkler J (2007) Physical activity 
fails to rescue hippocampal neurogenesis deficits in the R6/2 mouse model of Huntington's disease. Brain Res 1155:24-33

134. Schwarcz R, Guidetti P, Sathyasaikumar KV, Muchowski PJ (2010) Of mice, rats and men: revisiting the quinolinic acid hypothesis of Huntington's disease. Prog Neurobiol 90(2):230-245

135. Figueredo-Cardenas G, Harris CL, Anderson KD, Reiner A (1998) Relative resistance of striatal neurons containing calbindin or parvalbumin to quinolinic acid-mediated excitotoxicity compared to other striatal neuron types. Exp Neurol 149(2):356-372

136. Foster AC, Collins JF, Schwarcz R (1983) On the excitotoxic properties of quinolinic acid, 2,3-piperidine dicarboxylic acids and structurally related compounds. Neuropharmacology 22 (12A):1331-1342

137. Graham RK, Pouladi MA, Joshi P et al (2009) Differential susceptibility to excitotoxic stress in YAC128 mouse models of Huntington disease between initiation and progression of disease. J Neurosci 29(7):2193-2204

138. Zeron MM, Hansson O, Chen N, Wellington CL, Leavitt BR, Brundin P, Hayden MR, Raymond LA (2002) Increased sensitivity to $N$-methyl-D-aspartate receptor-mediated excitotoxicity in a mouse model of Huntington's disease. Neuron 33(6):849-860

139. Levine MS, Klapstein GJ, Koppel A et al (1999) Enhanced sensitivity to N-methyl-D-aspartate receptor activation in transgenic and knock-in mouse models of Huntington's disease. J Neurosci Res 58(4):515-532

140. Cummings DM, Cepeda C, Levine MS (2010) Alterations in striatal synaptic transmission are consistent across genetic mouse models of Huntington's disease. ASN Neuro 2(3):e00036

141. Klapstein GJ, Fisher RS, Zanjani H, Cepeda C, Jokel ES, Chesselet MF, Levine MS (2001) Electrophysiological and morphological changes in striatal spiny neurons in R6/2 Huntington's disease transgenic mice. J Neurophysiol 86(6):2667-2677

142. Starling AJ, André VM, Cepeda C, de Lima M, Chandler SH, Levine MS (2005) Alterations in $N$-methyl-D-aspartate receptor sensitivity and magnesium blockade occur early in development in the R6/2 mouse model of Huntington's disease. J Neurosci Res 82(3):377-386

143. André VM, Cepeda C, Venegas A, Gomez Y, Levine MS (2006) Altered cortical glutamate receptor function in the R6/2 model of Huntington's disease. J Neurophysiol 95 (4):2108-2119

144. Cummings DM, André VM, Uzgil BO, Gee SM, Fisher YE, Cepeda C, Levine MS (2009) Alterations in cortical excitation and inhibition in genetic mouse models of Huntington's disease. J Neurosci 29(33):10371-10386

145. Cepeda C, Wu N, André VM, Cummings DM, Levine MS (2007) The corticostriatal pathway in Huntington's disease. Prog Neurobiol 81(5-6):253-271

146. Guidetti P, Bates GP, Graham RK, Hayden MR, Leavitt BR, MacDonald ME, Slow EJ, Wheeler VC, Woodman B, Schwarcz R (2006) Elevated brain 3-hydroxykynurenine and quinolinate levels in Huntington disease mice. Neurobiol Dis 23(1):190-197

147. Fan MMY, Raymond LA (2007) $N$-methyl-D-aspartate (NMDA) receptor function and excitotoxicity in Huntington's disease. Prog Neurobiol 81(5-6):272-293

148. Léveillé F, El Gaamouch F, Gouix E, Lecocq M, Lobner D, Nicole O, Buisson A (2008) Neuronal viability is controlled by a functional relation between synaptic and extrasynaptic NMDA receptors. FASEB J 22(12):4258-4271

149. Okamoto S, Pouladi MA, Talantova M et al (2009) Balance between synaptic versus extrasynaptic NMDA receptor activity influences inclusions and neurotoxicity of mutant huntingtin. Nat Med 15(12):1407-1413

150. Milnerwood AJ, Gladding CM, Pouladi MA et al (2010) Early increase in extrasynaptic NMDA receptor signaling and expression contributes to phenotype onset in Huntington's disease mice. Neuron 65(2):178-190

151. Stanika RI, Pivovarova NB, Brantner CA, Watts CA, Winters CA, Andrews SB (2009) Coupling diverse routes of calcium entry to mitochondrial dysfunction and glutamate excitotoxicity. Proc Natl Acad Sci U S A 106(24):9854-9859

152. Tallaksen-Greene SJ, Janiszewska A, Benton K, Ruprecht L, Albin RL (2010) Lack of efficacy of NMDA receptor-NR2B selective antagonists in the R6/2 model of Huntington disease. Exp Neurol 225(2):402-407

153. Schilling G, Coonfield ML, Ross CA, Borchelt DR (2001) Coenzyme Q10 and remacemide hydrochloride ameliorate motor deficits in a Huntington's disease transgenic mouse model. Neurosci Lett 315(3):149-153

154. Ferrante RJ, Andreassen OA, Dedeoglu A, Ferrante KL, Jenkins BG, Hersch SM, Beal MF (2002) Therapeutic effects of coenzyme Q10 and remacemide in transgenic mouse models of Huntington's disease. J Neurosci 22 (5):1592-1599

155. Gianfriddo M, Melani A, Turchi D, Giovannini MG, Pedata F (2004) Adenosine and glutamate extracellular concentrations and mitogen-activated protein kinases in the striatum of Huntington transgenic mice. Selective antagonism of adenosine A2A receptors reduces transmitter outflow. Neurobiol Dis 17(1):77-88

156. Domenici MR, Scattoni ML, Martire A, Lastoria G, Potenza RL, Borioni A, Venerosi A, Calamandrei G, Popoli P (2007) Behavioral and electrophysiological effects of the adenosine A2A receptor antagonist SCH 58261 in R6/2 Huntington's disease mice. Neurobiol Dis 28(2):197-205

157. Chiang M-C, Chen H-M, Lai H-L, Chen H-W, Chou S-Y, Chen C-M, Tsai F-J, Chern Y (2009) The A2A adenosine receptor rescues the urea cycle deficiency of Huntington's disease by enhancing the activity of the ubiquitin-proteasome system. Hum Mol Genet 18(16):2929-2942

158. Huang N-K, Lin J-H, Lin J-T et al (2011) A new drug design targeting the adenosinergic system for Huntington's disease. PLoS One 6(6):e20934

159. Chou S-Y, Lee Y-C, Chen H-M et al (2005) CGS21680 attenuates symptoms of Huntington's disease in a transgenic mouse model. J Neurochem 93(2):310-320

160. Schiefer J, Sprünken A, Puls C, Lüesse H-G, Milkereit A, Milkereit E, Johann V, Kosinski CM (2004) The metabotropic glutamate receptor 5 antagonist MPEP and the mGluR2 agonist LY379268 modify disease progression in a transgenic mouse model of Huntington's disease. Brain Res 1019(1-2):246-254

161. Reiner A, Lafferty DC, Wang HB, Del Mar N, Deng YP (2012) The group 2 metabotropic glutamate receptor agonist LY379268 rescues neuronal, neurochemical and motor abnormalities in R6/2 Huntington's disease mice. Neurobiol Dis 47(1):75-91

162. Miller BR, Dorner JL, Shou M, Sari Y, Barton SJ, Sengelaub DR, Kennedy RT, Rebec GV (2008) Up-regulation of GLT1 expression increases glutamate uptake and attenuates the Huntington's disease phenotype in the R6/2 mouse. Neuroscience 153(1):329-337

163. Sari Y, Prieto AL, Barton SJ, Miller BR, Rebec GV (2010) Ceftriaxone-induced up-regulation of cortical and striatal GLT1 in the R6/2 model of Huntington's disease. J Biomed Sci 17:62

164. Figiel M, Engele J (2000) Pituitary adenylate cyclase-activating polypeptide (PACAP), a neuron-derived peptide regulating glial glutamate transport and metabolism. J Neurosci 20(10):3596-3605

165. Figiel M, Maucher T, Rozyczka J, Bayatti N, Engele J (2003) Regulation of glial glutamate transporter expression by growth factors. Exp Neurol 183(1):124-135

166. Tang T-S, Chen X, Liu J, Bezprozvanny I (2007) Dopaminergic signaling and striatal neurodegeneration in Huntington's disease. J Neurosci 27(30):7899-7910 
167. Wang H, Chen X, Li Y, Tang T-S, Bezprozvanny I (2010) Tetrabenazine is neuroprotective in Huntington's disease mice. Mol Neurodegener 5:18

168. Masuda N, Peng Q, Li Q, Jiang M, Liang Y, Wang X, Zhao M, Wang W, Ross CA, Duan W (2008) Tiagabine is neuroprotective in the N171-82Q and R6/2 mouse models of Huntington's disease. Neurobiol Dis 30(3):293-302

169. Dowie MJ, Howard ML, Nicholson LFB, Faull RLM, Hannan AJ, Glass M (2010) Behavioural and molecular consequences of chronic cannabinoid treatment in Huntington's disease transgenic mice. Neuroscience 170(1):324-336

170. Thevandavakkam MA, Schwarcz R, Muchowski PJ, Giorgini F (2010) Targeting kynurenine 3-monooxygenase (KMO): implications for therapy in Huntington's disease. CNS Neurol Disord Drug Targets 9(6):791-800

171. Guidetti P, Luthi-Carter RE, Augood SJ, Schwarcz R (2004) Neostriatal and cortical quinolinate levels are increased in early grade Huntington's disease. Neurobiol Dis 17(3):455-461

172. Sathyasaikumar KV, Stachowski EK, Amori L, Guidetti P, Muchowski PJ, Schwarcz R (2010) Dysfunctional kynurenine pathway metabolism in the R6/2 mouse model of Huntington's disease. J Neurochem 113(6):1416-1425

173. Campesan S, Green EW, Breda C, Sathyasaikumar KV, Muchowski PJ, Schwarcz R, Kyriacou CP, Giorgini F (2011) The kynurenine pathway modulates neurodegeneration in a Drosophila model of Huntington's disease. Curr Biol 21(11):961-966

174. Zwilling D, Huang S-Y, Sathyasaikumar KV et al (2011) Kynurenine 3-monooxygenase inhibition in blood ameliorates neurodegeneration. Cell 145(6):863-874

175. Gu M, Gash MT, Mann VM, Javoy-Agid F, Cooper JM, Schapira AH (1996) Mitochondrial defect in Huntington's disease caudate nucleus. Ann Neurol 39(3):385-389

176. Browne SE, Bowling AC, MacGarvey U, Baik MJ, Berger SC, Muqit MM, Bird ED, Beal MF (1997) Oxidative damage and metabolic dysfunction in Huntington's disease: selective vulnerability of the basal ganglia. Ann Neurol 41(5):646-653

177. Panov A, Obertone T, Bennett-Desmelik J, Greenamyre JT (1999) $\mathrm{Ca}(2+)$-dependent permeability transition and complex I activity in lymphoblast mitochondria from normal individuals and patients with Huntington's or Alzheimer's disease. Ann N Y Acad Sci 893:365-368

178. Panov AV, Gutekunst C-A, Leavitt BR, Hayden MR, Burke JR, Strittmatter WJ, Greenamyre JT (2002) Early mitochondrial calcium defects in Huntington's disease are a direct effect of polyglutamines. Nat Neurosci 5(8):731-736

179. Milakovic T, Johnson GVW (2005) Mitochondrial respiration and ATP production are significantly impaired in striatal cells expressing mutant huntingtin. J Biol Chem 280(35):30773-30782

180. Cui L, Jeong H, Borovecki F, Parkhurst CN, Tanese N, Krainc D (2006) Transcriptional repression of PGC-1alpha by mutant huntingtin leads to mitochondrial dysfunction and neurodegeneration. Cell 127(1):59-69

181. Weydt P, Pineda VV, Torrence AE et al (2006) Thermoregulatory and metabolic defects in Huntington's disease transgenic mice implicate PGC-1alpha in Huntington's disease neurodegeneration. Cell Metab 4(5):349-362

182. Lemasters JJ, Theruvath TP, Zhong Z, Nieminen A-L (2009) Mitochondrial calcium and the permeability transition in cell death. Biochim Biophys Acta 1787(11):1395-1401

183. Choo YS, Johnson GVW, MacDonald M, Detloff PJ, Lesort M (2004) Mutant huntingtin directly increases susceptibility of mitochondria to the calcium-induced permeability transition and cytochrome c release. Hum Mol Genet 13(14):1407-1420

184. Block-Galarza J, Chase KO, Sapp E, Vaughn KT, Vallee RB, DiFiglia M, Aronin N (1997) Fast transport and retrograde movement of huntingtin and HAP 1 in axons. Neuroreport 8(910):2247-2251

185. Orr AL, Li S, Wang C-E, Li H, Wang J, Rong J, Xu X, Mastroberardino PG, Greenamyre JT, Li X-J (2008) N-terminal mutant huntingtin associates with mitochondria and impairs mitochondrial trafficking. J Neurosci 28(11):2783-2792

186. Chang DTW, Rintoul GL, Pandipati S, Reynolds IJ (2006) Mutant huntingtin aggregates impair mitochondrial movement and trafficking in cortical neurons. Neurobiol Dis 22(2):388-400

187. Smith KM, Matson S, Matson WR, Cormier K, Del Signore SJ, Hagerty SW, Stack EC, Ryu H, Ferrante RJ (2006) Dose ranging and efficacy study of high-dose coenzyme Q10 formulations in Huntington's disease mice. Biochim Biophys Acta 1762(6):616-626

188. Stack EC, Smith KM, Ryu H, Cormier K, Chen M, Hagerty SW, Del Signore SJ, Cudkowicz ME, Friedlander RM, Ferrante RJ (2006) Combination therapy using minocycline and coenzyme Q10 in R6/2 transgenic Huntington's disease mice. Biochim Biophys Acta 1762(3):373-380

189. Yang L, Calingasan NY, Wille EJ, Cormier K, Smith K, Ferrante RJ, Beal MF (2009) Combination therapy with coenzyme Q10 and creatine produces additive neuroprotective effects in models of Parkinson's and Huntington's diseases. J Neurochem 109(5):1427-1439

190. Menalled LB, Patry M, Ragland N et al (2010) Comprehensive behavioral testing in the R6/2 mouse model of Huntington's disease shows no benefit from CoQ10 or minocycline. PLoS One 5(3):e9793

191. Bhagavan HN, Chopra RK (2006) Coenzyme Q10: absorption, tissue uptake, metabolism and pharmacokinetics. Free Radic Res 40(5):445-453

192. Villalba JM, Parrado C, Santos-Gonzalez M, Alcain FJ (2010) Therapeutic use of coenzyme Q10 and coenzyme Q10-related compounds and formulations. Expert Opin Investig Drugs 19 (4):535-554

193. Andreassen OA, Ferrante RJ, Huang HM et al (2001) Dichloroacetate exerts therapeutic effects in transgenic mouse models of Huntington's disease. Ann Neurol 50(1):112-117

194. Andreassen OA, Ferrante RJ, Dedeoglu A, Beal MF (2001) Lipoic acid improves survival in transgenic mouse models of Huntington's disease. Neuroreport 12(15):3371-3373

195. Dedeoglu A, Kubilus JK, Yang L, Ferrante KL, Hersch SM, Beal MF, Ferrante RJ (2003) Creatine therapy provides neuroprotection after onset of clinical symptoms in Huntington's disease transgenic mice. J Neurochem 85(6):1359-1367

196. Andreassen OA, Dedeoglu A, Ferrante RJ et al (2001) Creatine increase survival and delays motor symptoms in a transgenic animal model of Huntington's disease. Neurobiol Dis 8(3):479-491

197. Ferrante RJ, Andreassen OA, Jenkins BG, Dedeoglu A, Kuemmerle S, Kubilus JK, Kaddurah-Daouk R, Hersch SM, Beal MF (2000) Neuroprotective effects of creatine in a transgenic mouse model of Huntington's disease. J Neurosci 20 (12):4389-4397

198. Ruskin DN, Ross JL, Kawamura M Jr, Ruiz TL, Geiger JD, Masino SA (2011) A ketogenic diet delays weight loss and does not impair working memory or motor function in the R6/2 $1 \mathrm{~J}$ mouse model of Huntington's disease. Physiol Behav 103(5):501-507

199. Emerit J, Edeas M, Bricaire F (2004) Neurodegenerative diseases and oxidative stress. Biomed Pharmacother 58(1):39-46

200. Lee J, Kosaras B, Del Signore SJ, Cormier K, McKee A, Ratan RR, Kowall NW, Ryu H (2011) Modulation of lipid peroxidation and mitochondrial function improves neuropathology in Huntington's disease mice. Acta Neuropathol 121(4):487-498

201. Keene CD, Rodrigues CMP, Eich T, Chhabra MS, Steer CJ, Low WC (2002) Tauroursodeoxycholic acid, a bile acid, is neuroprotective in a transgenic animal model of Huntington's disease. Proc Natl Acad Sci U S A 99(16):10671-10676 
202. Klivenyi P, Ferrante RJ, Gardian G, Browne S, Chabrier P-E, Beal MF (2003) Increased survival and neuroprotective effects of BN82451 in a transgenic mouse model of Huntington's disease. J Neurochem 86(1):267-272

203. Rebec GV, Barton SJ, Marseilles AM, Collins K (2003) Ascorbate treatment attenuates the Huntington behavioral phenotype in mice. Neuroreport 14(9):1263-1265

204. Vamos E, Voros K, Vecsei L, Klivenyi P (2010) Neuroprotective effects of L-carnitine in a transgenic animal model of Huntington's disease. Biomed Pharmacother 64(4):282-286

205. Stack C, Ho D, Wille E, Calingasan NY, Williams C, Liby K, Sporn M, Dumont M, Beal MF (2010) Triterpenoids CDDOethyl amide and CDDO-trifluoroethyl amide improve the behavioral phenotype and brain pathology in a transgenic mouse model of Huntington's disease. Free Radic Biol Med 49(2):147-158

206. Ellrichmann G, Petrasch-Parwez E, Lee D-H, Reick C, Arning L, Saft C, Gold R, Linker RA (2011) Efficacy of fumaric acid esters in the R6/2 and YAC128 models of Huntington's disease. PLoS One 6(1):e16172

207. Chaturvedi RK, Adhihetty P, Shukla S et al (2009) Impaired PGC-1alpha function in muscle in Huntington's disease. Hum Mol Genet 18(16):3048-3065

208. Ho DJ, Calingasan NY, Wille E, Dumont M, Beal MF (2010) Resveratrol protects against peripheral deficits in a mouse model of Huntington's disease. Exp Neurol 225(1):74-84

209. Jeong H, Cohen DE, Cui L, Supinski A, Savas JN, Mazzulli JR, Yates JR 3rd, Bordone L, Guarente L, Krainc D (2012) Sirt1 mediates neuroprotection from mutant huntingtin by activation of the TORC1 and CREB transcriptional pathway. Nat Med 18(1):159-165

210. Jiang M, Wang J, Fu J et al (2012) Neuroprotective role of Sirt1 in mammalian models of Huntington's disease through activation of multiple Sirt1 targets. Nat Med 18(1):153-158

211. Wang H, Guan Y, Wang X et al (2007) Nortriptyline delays disease onset in models of chronic neurodegeneration. Eur $\mathrm{J}$ Neurosci 26(3):633-641

212. Perry GM, Tallaksen-Greene S, Kumar A, Heng MY, Kneynsberg A, van Groen T, Detloff PJ, Albin RL, Lesort M (2010) Mitochondrial calcium uptake capacity as a therapeutic target in the R6/2 mouse model of Huntington's disease. Hum Mol Genet 19(17):3354-3371

213. Sánchez I, Xu CJ, Juo P, Kakizaka A, Blenis J, Yuan J (1999) Caspase- 8 is required for cell death induced by expanded polyglutamine repeats. Neuron 22(3):623-633

214. Chen M, Ona VO, Li M et al (2000) Minocycline inhibits caspase- 1 and caspase- 3 expression and delays mortality in a transgenic mouse model of Huntington disease. Nat Med 6 (7):797-801

215. Gervais FG, Singaraja R, Xanthoudakis S et al (2002) Recruitment and activation of caspase- 8 by the Huntingtin-interacting protein Hip-1 and a novel partner Hippi. Nat Cell Biol 4(2):95-105

216. Hermel E, Gafni J, Propp SS et al (2004) Specific caspase interactions and amplification are involved in selective neuronal vulnerability in Huntington's disease. Cell Death Differ 11(4):424-438

217. Kiechle T, Dedeoglu A, Kubilus J, Kowall NW, Beal MF, Friedlander RM, Hersch SM, Ferrante RJ (2002) Cytochrome C and caspase- 9 expression in Huntington's disease. Neuromolecular Med 1(3):183-195

218. Zhang H, Li Q, Graham RK, Slow E, Hayden MR, Bezprozvanny I (2008) Full length mutant huntingtin is required for altered $\mathrm{Ca} 2+$ signaling and apoptosis of striatal neurons in the YAC mouse model of Huntington's disease. Neurobiol Dis 31(1):80-88

219. Chou A-H, Yeh T-H, Kuo Y-L, Kao Y-C, Jou M-J, Hsu C-Y, Tsai SR, Kakizuka A, Wang H-L (2006) Polyglutamine-expanded ataxin3 activates mitochondrial apoptotic pathway by upregulating Bax and downregulating Bcl-xL. Neurobiol Dis 21(2):333-345
220. Wang H-L, Yeh T-H, Chou A-H, Kuo Y-L, Luo L-J, He C-Y, Huang P-C, Li AH (2006) Polyglutamine-expanded ataxin-7 activates mitochondrial apoptotic pathway of cerebellar neurons by upregulating Bax and downregulating Bcl-x(L). Cell Signal 18 (4):541-552

221. Chou A-H, Lin A-C, Hong K-Y, Hu S-H, Chen Y-L, Chen J-Y, Wang H-L (2011) p53 activation mediates polyglutamineexpanded ataxin-3 upregulation of Bax expression in cerebellar and pontine nuclei neurons. Neurochem Int 58(2):145-152

222. Young JE, Garden GA, Martinez RA et al (2009) Polyglutamineexpanded androgen receptor truncation fragments activate a Baxdependent apoptotic cascade mediated by DP5/Hrk. J Neurosci 29(7):1987-1997

223. Wellington CL, Ellerby LM, Gutekunst C-A et al (2002) Caspase cleavage of mutant huntingtin precedes neurodegeneration in Huntington's disease. J Neurosci 22(18):7862-7872

224. Berke SJS, Schmied FAF, Brunt ER, Ellerby LM, Paulson HL (2004) Caspase-mediated proteolysis of the polyglutamine disease protein ataxin-3. J Neurochem 89(4):908-918

225. Young JE, Gouw L, Propp S et al (2007) Proteolytic cleavage of ataxin-7 by caspase-7 modulates cellular toxicity and transcriptional dysregulation. J Biol Chem 282(41):30150-30160

226. Ellerby LM, Hackam AS, Propp SS et al (1999) Kennedy's disease: caspase cleavage of the androgen receptor is a crucial event in cytotoxicity. J Neurochem 72(1):185-195

227. Ellerby LM, Andrusiak RL, Wellington CL et al (1999) Cleavage of atrophin-1 at caspase site aspartic acid 109 modulates cytotoxicity. J Biol Chem 274(13):8730-8736

228. Graham RK, Deng Y, Slow EJ et al (2006) Cleavage at the caspase- 6 site is required for neuronal dysfunction and degeneration due to mutant huntingtin. Cell 125(6):1179-1191

229. Tebbenkamp ATN, Green C, Xu G et al (2011) Transgenic mice expressing caspase-6-derived $\mathrm{N}$-terminal fragments of mutant huntingtin develop neurologic abnormalities with predominant cytoplasmic inclusion pathology composed largely of a smaller proteolytic derivative. Hum Mol Genet 20(14):2770-2782

230. Waldron-Roby E, Ratovitski T, Wang X et al (2012) Transgenic mouse model expressing the caspase 6 fragment of mutant huntingtin. J Neurosci 32(1):183-193

231. Nagley P, Higgins GC, Atkin JD, Beart PM (2010) Multifaceted deaths orchestrated by mitochondria in neurones. Biochim Biophys Acta 1802(1):167-185

232. Ona VO, Li M, Vonsattel JP et al (1999) Inhibition of caspase-1 slows disease progression in a mouse model of Huntington's disease. Nature 399(6733):263-267

233. Wang X, Zhu S, Drozda M, Zhang W, Stavrovskaya IG, Cattaneo E, Ferrante RJ, Kristal BS, Friedlander RM (2003) Minocycline inhibits caspase-independent and -dependent mitochondrial cell death pathways in models of Huntington's disease. Proc Natl Acad Sci USA 100(18):10483-10487

234. Diguet E, Fernagut P-O, Wei X, Du Y, Rouland R, Gross C, Bezard E, Tison F (2004) Deleterious effects of minocycline in animal models of Parkinson's disease and Huntington's disease. Eur J Neurosci 19(12):3266-3276

235. Mievis S, Levivier M, Communi D, Vassart G, Brotchi J, Ledent C, Blum D (2007) Lack of minocycline efficiency in genetic models of Huntington's disease. Neuromolecular Med 9(1):47-54

236. Hersch S, Fink K, Vonsattel JP, Friedlander RM (2003) Minocycline is protective in a mouse model of Huntington's disease. Ann Neurol 54(6):841, author reply 842-843

237. Bonelli RM, Hödl AK, Hofmann P, Kapfhammer H-P (2004) Neuroprotection in Huntington's disease: a 2-year study on minocycline. Int Clin Psychopharmacol 19(6):337-342

238. Thomas M, Ashizawa T, Jankovic J (2004) Minocycline in Huntington's disease: a pilot study. Mov Disord 19(6):692-695 
239. Huntington Study Group (2004) Minocycline safety and tolerability in Huntington disease. Neurology 63(3):547-549

240. Plane JM, Shen Y, Pleasure DE, Deng W (2010) Prospects for minocycline neuroprotection. Arch Neurol 67(12):1442-1448

241. Gordon PH, Moore DH, Miller RG et al (2007) Efficacy of minocycline in patients with amyotrophic lateral sclerosis: a phase III randomised trial. Lancet Neurol 6(12):1045-1053

242. Huntington Study Group DOMINO Investigators (2010) A futility study of minocycline in Huntington's disease. Mov Disord 25 (13):2219-2224

243. Wang X, Zhu S, Pei Z et al (2008) Inhibitors of cytochrome c release with therapeutic potential for Huntington's disease. J Neurosci 28(38):9473-9485

244. Díaz-Hernández M, Díez-Zaera M, Sánchez-Nogueiro J, GómezVillafuertes R, Canals JM, Alberch J, Miras-Portugal MT, Lucas JJ (2009) Altered P2X7-receptor level and function in mouse models of Huntington's disease and therapeutic efficacy of antagonist administration. FASEB J 23(6):1893-1906

245. Arzberger T, Krampfl K, Leimgruber S, Weindl A (1997) Changes of NMDA receptor subunit (NR1, NR2B) and glutamate transporter (GLT1) mRNA expression in Huntington's disease - an in situ hybridization study. J Neuropathol Exp Neurol 56(4):440-454

246. Augood SJ, Faull RL, Love DR, Emson PC (1996) Reduction in enkephalin and substance P messenger RNA in the striatum of early grade Huntington's disease: a detailed cellular in situ hybridization study. Neuroscience 72(4):1023-1036

247. Evert BO, Vogt IR, Vieira-Saecker AM, Ozimek L, de Vos RAI, Brunt ERP, Klockgether T, Wüllner U (2003) Gene expression profiling in ataxin-3 expressing cell lines reveals distinct effects of normal and mutant ataxin-3. J Neuropathol Exp Neurol 62 (10): $1006-1018$

248. Lin X, Antalffy B, Kang D, Orr HT, Zoghbi HY (2000) Polyglutamine expansion down-regulates specific neuronal genes before pathologic changes in SCA1. Nat Neurosci 3(2):157-163

249. Luthi-Carter R, Strand AD, Hanson SA et al (2002) Polyglutamine and transcription: gene expression changes shared by DRPLA and Huntington's disease mouse models reveal context-independent effects. Hum Mol Genet 11 (17):1927-1937

250. Helmlinger D, Hardy S, Sasorith S et al (2004) Ataxin-7 is a subunit of GCN5 histone acetyltransferase-containing complexes. Hum Mol Genet 13(12):1257-1265

251. Tsai C-C, Kao H-Y, Mitzutani A, Banayo E, Rajan H, McKeown M, Evans RM (2004) Ataxin 1, a SCA1 neurodegenerative disorder protein, is functionally linked to the silencing mediator of retinoid and thyroid hormone receptors. Proc Natl Acad Sci USA 101(12):4047-4052

252. Mizutani A, Wang L, Rajan H, Vig PJS, Alaynick WA, Thaler JP, Tsai C-C (2005) Boat, an AXH domain protein, suppresses the cytotoxicity of mutant ataxin-1. EMBO J 24(18):3339-3351

253. Tong X, Gui H, Jin F, Heck BW, Lin P, Ma J, Fondell JD, Tsai C$\mathrm{C}$ (2011) Ataxin-1 and Brother of ataxin-1 are components of the Notch signalling pathway. EMBO Rep 12(5):428-435

254. Li F, Macfarlan T, Pittman RN, Chakravarti D (2002) Ataxin-3 is a histone-binding protein with two independent transcriptional corepressor activities. J Biol Chem 277(47):45004-45012

255. Evert BO, Araujo J, Vieira-Saecker AM, de Vos RAI, Harendza S, Klockgether T, Wüllner U (2006) Ataxin-3 represses transcription via chromatin binding, interaction with histone deacetylase 3, and histone deacetylation. J Neurosci 26(44):1147411486

256. Shimohata T, Nakajima T, Yamada M et al (2000) Expanded polyglutamine stretches interact with TAFII130, interfering with CREB-dependent transcription. Nat Genet 26(1):29-36
257. Okazawa H, Rich T, Chang A et al (2002) Interaction between mutant ataxin-1 and PQBP-1 affects transcription and cell death. Neuron 34(5):701-713

258. Bae B-I, Xu H, Igarashi S et al (2005) p53 mediates cellular dysfunction and behavioral abnormalities in Huntington's disease. Neuron 47(1):29-41

259. Li S-H, Cheng AL, Zhou H, Lam S, Rao M, Li H, Li X-J (2002) Interaction of Huntington disease protein with transcriptional activator Sp1. Mol Cell Biol 22(5):1277-1287

260. Arango M, Holbert S, Zala D et al (2006) CA150 expression delays striatal cell death in overexpression and knock-in conditions for mutant huntingtin neurotoxicity. J Neurosci 26 (17):4649-4659

261. Desplats PA, Lambert JR, Thomas EA (2008) Functional roles for the striatal-enriched transcription factor, Bcl11b, in the control of striatal gene expression and transcriptional dysregulation in Huntington's disease. Neurobiol Dis 31(3):298-308

262. Butler R, Bates GP (2006) Histone deacetylase inhibitors as therapeutics for polyglutamine disorders. Nat Rev Neurosci 7(10):784-796

263. McCampbell A, Taylor JP, Taye AA et al (2000) CREB-binding protein sequestration by expanded polyglutamine. Hum Mol Genet 9(14):2197-2202

264. Nucifora FC Jr, Sasaki M, Peters MF et al (2001) Interference by huntingtin and atrophin-1 with cbp-mediated transcription leading to cellular toxicity. Science 291(5512):2423-2428

265. Jiang H, Nucifora FC Jr, Ross CA, DeFranco DB (2003) Cell death triggered by polyglutamine-expanded huntingtin in a neuronal cell line is associated with degradation of CREB-binding protein. Hum Mol Genet 12(1):1-12

266. Stenoien DL, Mielke M, Mancini MA (2002) Intranuclear ataxin1 inclusions contain both fast- and slow-exchanging components. Nat Cell Biol 4(10):806-810

267. Sadri-Vakili G, Bouzou B, Benn CL et al (2007) Histones associated with downregulated genes are hypo-acetylated in Huntington's disease models. Hum Mol Genet 16(11):1293-1306

268. Giampà $\mathrm{C}$, Middei $\mathrm{S}$, Patassini $\mathrm{S}$, Borreca $\mathrm{A}$, Marullo $\mathrm{F}$, Laurenti D, Bernardi G, Ammassari-Teule M, Fusco FR (2009) Phosphodiesterase type IV inhibition prevents sequestration of CREB binding protein, protects striatal parvalbumin interneurons and rescues motor deficits in the R6/2 mouse model of Huntington's disease. Eur J Neurosci 29(5):902-910

269. Chou A-H, Chen S-Y, Yeh T-H, Weng Y-H, Wang H-L (2011) HDAC inhibitor sodium butyrate reverses transcriptional downregulation and ameliorates ataxic symptoms in a transgenic mouse model of SCA3. Neurobiol Dis 41(2):481-488

270. Minamiyama M, Katsuno M, Adachi H, Waza M, Sang C, Kobayashi Y, Tanaka F, Doyu M, Inukai A, Sobue G (2004) Sodium butyrate ameliorates phenotypic expression in a transgenic mouse model of spinal and bulbar muscular atrophy. Hum Mol Genet 13(11):1183-1192

271. Ying M, Xu R, Wu X, Zhu H, Zhuang Y, Han M, Xu T (2006) Sodium butyrate ameliorates histone hypoacetylation and neurodegenerative phenotypes in a mouse model for DRPLA. J Biol Chem 281(18):12580-12586

272. Gardian G, Browne SE, Choi D-K et al (2005) Neuroprotective effects of phenylbutyrate in the N171-82Q transgenic mouse model of Huntington's disease. J Biol Chem 280(1):556-563

273. Zádori D, Geisz A, Vámos E, Vécsei L, Klivényi P (2009) Valproate ameliorates the survival and the motor performance in a transgenic mouse model of Huntington's disease. Pharmacol Biochem Behav 94(1):148-153

274. Ferrante RJ, Kubilus JK, Lee J et al (2003) Histone deacetylase inhibition by sodium butyrate chemotherapy ameliorates the neurodegenerative phenotype in Huntington's disease mice. J Neurosci 23(28):9418-9427 
275. Hockly E, Richon VM, Woodman B et al (2003) Suberoylanilide hydroxamic acid, a histone deacetylase inhibitor, ameliorates motor deficits in a mouse model of Huntington's disease. Proc Natl Acad Sci U S A 100(4):2041-2046

276. Thomas EA, Coppola G, Desplats PA et al (2008) The HDAC inhibitor $4 \mathrm{~b}$ ameliorates the disease phenotype and transcriptional abnormalities in Huntington's disease transgenic mice. Proc Natl Acad Sci USA 105(40):15564-15569

277. Ryu H, Lee J, Hagerty SW, Soh BY, McAlpin SE, Cormier KA, Smith KM, Ferrante RJ (2006) ESET/SETDB1 gene expression and histone H3 (K9) trimethylation in Huntington's disease. Proc Natl Acad Sci U S A 103(50):19176-19181

278. Ferrante RJ, Ryu H, Kubilus JK et al (2004) Chemotherapy for the brain: the antitumor antibiotic mithramycin prolongs survival in a mouse model of Huntington's disease. J Neurosci 24(46):10335-10342

279. Stack EC, Del Signore SJ, Luthi-Carter R et al (2007) Modulation of nucleosome dynamics in Huntington's disease. Hum Mol Genet 16(10):1164-1175

280. Manji HK, Moore GJ, Chen G (2000) Lithium up-regulates the cytoprotective protein $\mathrm{Bcl}-2$ in the CNS in vivo: a role for neurotrophic and neuroprotective effects in manic depressive illness. J Clin Psychiatry 61(Suppl 9):82-96

281. Chen G, Masana MI, Manji HK (2000) Lithium regulates PKCmediated intracellular cross-talk and gene expression in the CNS in vivo. Bipolar Disord 2(3 Pt 2):217-236

282. Zhang F, Phiel CJ, Spece L, Gurvich N, Klein PS (2003) Inhibitory phosphorylation of glycogen synthase kinase-3 (GSK-3) in response to lithium. Evidence for autoregulation of GSK-3. J Biol Chem 278(35):33067-33077

283. Watase K, Gatchel JR, Sun Y, Emamian E, Atkinson R, Richman R, Mizusawa H, Orr HT, Shaw C, Zoghbi HY (2007) Lithium therapy improves neurological function and hippocampal dendritic arborization in a spinocerebellar ataxia type 1 mouse model. PLoS Med 4(5):e182

284. Wood NI, Morton AJ (2003) Chronic lithium chloride treatment has variable effects on motor behaviour and survival of mice transgenic for the Huntington's disease mutation. Brain Res Bull 61(4):375-383

285. Miller TW, Shirley TL, Wolfgang WJ, Kang X, Messer A (2003) DNA vaccination against mutant huntingtin ameliorates the HDR6/2 diabetic phenotype. Mol Ther 7(5 Pt 1):572-579

286. Bowman AB, Lam YC, Jafar-Nejad P, Chen H-K, Richman R, Samaco RC, Fryer JD, Kahle JJ, Orr HT, Zoghbi HY (2007) Duplication of Atxn11 suppresses SCA1 neuropathology by decreasing incorporation of polyglutamine-expanded ataxin-1 into native complexes. Nat Genet 39(3):373-379

287. Norflus F, Nanje A, Gutekunst C-A, Shi G, Cohen J, Bejarano M, Fox J, Ferrante RJ, Hersch SM (2004) Anti-inflammatory treatment with acetylsalicylate or rofecoxib is not neuroprotective in Huntington's disease transgenic mice. Neurobiol Dis 17(2):319-325

288. Andreassen OA, Dedeoglu A, Stanojevic V, Hughes DB, Browne SE, Leech CA, Ferrante RJ, Habener JF, Beal MF, Thomas MK (2002) Huntington's disease of the endocrine pancreas: insulin deficiency and diabetes mellitus due to impaired insulin gene expression. Neurobiol Dis 11(3):410-424

289. Josefsen K, Nielsen MD, Jørgensen KH, Bock T, Nørremølle A, Sørensen SA, Naver B, Hasholt L (2008) Impaired glucose tolerance in the R6/1 transgenic mouse model of Huntington's disease. J Neuroendocrinol 20(2):165-172

290. Strand AD, Aragaki AK, Shaw D et al (2005) Gene expression in Huntington's disease skeletal muscle: a potential biomarker. Hum Mol Genet 14(13):1863-1876

291. Hunt MJ, Morton AJ (2005) Atypical diabetes associated with inclusion formation in the R6/2 mouse model of Huntington's disease is not improved by treatment with hypoglycaemic agents. Exp Brain Res 166(2):220-229
292. Henriksen EJ (2002) Invited review: Effects of acute exercise and exercise training on insulin resistance. J Appl Physiol 93(2):788-796

293. Ma TC, Buescher JL, Oatis B, Funk JA, Nash AJ, Carrier RL, Hoyt KR (2007) Metformin therapy in a transgenic mouse model of Huntington's disease. Neurosci Lett 411(2):98-103

294. Martin B, Golden E, Carlson OD et al (2009) Exendin-4 improves glycemic control, ameliorates brain and pancreatic pathologies, and extends survival in a mouse model of Huntington's disease. Diabetes 58(2):318-328

295. Karpuj MV, Becher MW, Springer JE, Chabas D, Youssef S, Pedotti R, Mitchell D, Steinman L (2002) Prolonged survival and decreased abnormal movements in transgenic model of Huntington disease, with administration of the transglutaminase inhibitor cystamine. Nat Med 8(2):143-149

296. Dedeoglu A, Kubilus JK, Jeitner TM et al (2002) Therapeutic effects of cystamine in a murine model of Huntington's disease. J Neurosci 22(20):8942-8950

297. Wang X, Sarkar A, Cicchetti F, Yu M, Zhu A, Jokivarsi K, SaintPierre M, Brownell A-L (2005) Cerebral PET imaging and histological evidence of transglutaminase inhibitor cystamine induced neuroprotection in transgenic R6/2 mouse model of Huntington's disease. J Neurol Sci 231(1-2):57-66

298. Van Raamsdonk JM, Pearson J, Bailey CDC, Rogers DA, Johnson GVW, Hayden MR, Leavitt BR (2005) Cystamine treatment is neuroprotective in the YAC128 mouse model of Huntington disease. J Neurochem 95(1):210-220

299. Mastroberardino PG, Iannicola C, Nardacci R et al (2002) "Tissue" transglutaminase ablation reduces neuronal death and prolongs survival in a mouse model of Huntington's disease. Cell Death Differ 9(9):873-880

300. McConoughey SJ, Basso M, Niatsetskaya ZV et al (2010) Inhibition of transglutaminase 2 mitigates transcriptional dysregulation in models of Huntington disease. EMBO Mol Med 2(9):349-370

301. Morton AJ, Wood NI, Hastings MH, Hurelbrink C, Barker RA, Maywood ES (2005) Disintegration of the sleep-wake cycle and circadian timing in Huntington's disease. J Neurosci 25(1):157-163

302. Pedroso JL, Braga-Neto P, Felício AC, Dutra LA, Santos WAC, do Prado GF, Barsottini OGP (2011) Sleep disorders in machadojoseph disease: frequency, discriminative thresholds, predictive values, and correlation with ataxia-related motor and non-motor features. Cerebellum 10(2):291-295

303. Hara J, Beuckmann CT, Nambu T et al (2001) Genetic ablation of orexin neurons in mice results in narcolepsy, hypophagia, and obesity. Neuron 30(2):345-354

304. Pallier PN, Morton AJ (2009) Management of sleep/wake cycles improves cognitive function in a transgenic mouse model of Huntington's disease. Brain Res 1279:90-98

305. Pallier PN, Maywood ES, Zheng Z, Chesham JE, Inyushkin AN, Dyball R, Hastings MH, Morton AJ (2007) Pharmacological imposition of sleep slows cognitive decline and reverses dysregulation of circadian gene expression in a transgenic mouse model of Huntington's disease. J Neurosci 27(29):7869-7878

306. Van Raamsdonk JM, Murphy Z, Selva DM et al (2007) Testicular degeneration in Huntington disease. Neurobiol Dis 26(3):512-520

307. Katsuno M, Adachi H, Kume A, Li M, Nakagomi Y, Niwa H, Sang C, Kobayashi Y, Doyu M, Sobue G (2002) Testosterone reduction prevents phenotypic expression in a transgenic mouse model of spinal and bulbar muscular atrophy. Neuron 35(5):843-854

308. Katsuno M, Adachi H, Doyu M, Minamiyama M, Sang C, Kobayashi Y, Inukai A, Sobue G (2003) Leuprorelin rescues polyglutamine-dependent phenotypes in a transgenic mouse model of spinal and bulbar muscular atrophy. Nat Med 9(6):768-773

309. Chevalier-Larsen ES, O’Brien CJ, Wang H, Jenkins SC, Holder L, Lieberman AP, Merry DE (2004) Castration restores function and neurofilament alterations of aged symptomatic males in a 
transgenic mouse model of spinal and bulbar muscular atrophy. J Neurosci 24(20):4778-4786

310. Hult S, Schultz K, Soylu R, Petersén A (2010) Hypothalamic and neuroendocrine changes in Huntington's disease. Curr Drug Targets 11(10): 1237-1249

311. Mangiarini L, Sathasivam K, Seller M et al (1996) Exon 1 of the HD gene with an expanded CAG repeat is sufficient to cause a progressive neurological phenotype in transgenic mice. Cell 87 (3):493-506

312. Schilling G, Becher MW, Sharp AH et al (1999) Intranuclear inclusions and neuritic aggregates in transgenic mice expressing a mutant N-terminal fragment of huntingtin. Hum Mol Genet 8(3):397-407

313. Landles C, Sathasivam K, Weiss A et al (2010) Proteolysis of mutant huntingtin produces an exon 1 fragment that accumulates as an aggregated protein in neuronal nuclei in Huntington disease. J Biol Chem 285(12):8808-8823

314. Hodgson JG, Agopyan N, Gutekunst CA et al (1999) A YAC mouse model for Huntington's disease with full-length mutant huntingtin, cytoplasmic toxicity, and selective striatal neurodegeneration. Neuron 23(1):181-192

315. Slow EJ, van Raamsdonk J, Rogers D et al (2003) Selective striatal neuronal loss in a YAC128 mouse model of Huntington disease. Hum Mol Genet 12(13):1555-1567

316. Brooks S, Higgs G, Janghra N, Jones L, Dunnett SB (2012) Longitudinal analysis of the behavioural phenotype in YAC128 (C57BL/6 J) Huntington's disease transgenic mice. Brain Res Bull 88(2-3):113-120

317. Ferrante RJ (2009) Mouse models of Huntington's disease and methodological considerations for therapeutic trials. Biochim Biophys Acta 1792(6):506-520

318. Menalled LB, Sison JD, Dragatsis I, Zeitlin S, Chesselet M-F (2003) Time course of early motor and neuropathological anomalies in a knock-in mouse model of Huntington's disease with 140 CAG repeats. J Comp Neurol 465(1):11-26

319. Wheeler VC, White JK, Gutekunst CA et al (2000) Long glutamine tracts cause nuclear localization of a novel form of huntingtin in medium spiny striatal neurons in HdhQ92 and HdhQ111 knock-in mice. Hum Mol Genet 9(4):503-513

320. Gray M, Shirasaki DI, Cepeda C et al (2008) Full-length human mutant huntingtin with a stable polyglutamine repeat can elicit progressive and selective neuropathogenesis in BACHD mice. J Neurosci 28(24):6182-6195

321. Kotliarova S, Jana NR, Sakamoto N et al (2005) Decreased expression of hypothalamic neuropeptides in Huntington disease transgenic mice with expanded polyglutamine-EGFP fluorescent aggregates. J Neurochem 93(3):641-653

322. Hoppitt T, Pall H, Calvert M, Gill P, Yao G, Ramsay J, James G, Conduit J, Sackley C (2011) A systematic review of the incidence and prevalence of long-term neurological conditions in the UK. Neuroepidemiology 36(1):19-28

323. Klockgether T (2008) The clinical diagnosis of autosomal dominant spinocerebellar ataxias. Cerebellum 7(2):101-105

324. Burright EN, Clark HB, Servadio A, Matilla T, Feddersen RM, Yunis WS, Duvick LA, Zoghbi HY, Orr HT (1995) SCA1 transgenic mice: a model for neurodegeneration caused by an expanded CAG trinucleotide repeat. Cell 82(6):937-948

325. Watase K, Weeber EJ, Xu B et al (2002) A long CAG repeat in the mouse Sca1 locus replicates SCA1 features and reveals the impact of protein solubility on selective neurodegeneration. Neuron 34(6):905-919

326. Yoo SY, Pennesi ME, Weeber EJ, Xu B, Atkinson R, Chen S, Armstrong DL, Wu SM, Sweatt JD, Zoghbi HY (2003) SCA7 knockin mice model human SCA7 and reveal gradual accumulation of mutant ataxin-7 in neurons and abnormalities in short-term plasticity. Neuron 37(3):383-401
327. Sato T, Miura M, Yamada M et al (2009) Severe neurological phenotypes of Q129 DRPLA transgenic mice serendipitously created by en masse expansion of CAG repeats in Q76 DRPLA mice. Hum Mol Genet 18(4):723-736

328. Willner P (1986) Validation criteria for animal models of human mental disorders: learned helplessness as a paradigm case. Prog Neuropsychopharmacol Biol Psychiatry 10(6):677-690

329. Willner P (1991) Methods for assessing the validity of animals models of human psychopathology. Animal models in psychiatry. The Humana Press Inc., Clifton, pp 1-24

330. Heng MY, Detloff PJ, Albin RL (2008) Rodent genetic models of Huntington disease. Neurobiol Dis 32(1):1-9

331. Dorsey R, Shoulson I (2011) Huntington's disease, clinical experimental therapeutics. Neurobiology of Huntington's disease: applications to drug discovery. CRC Press, Boca Raton

332. Dunnett SB, Carter RJ, Watts C, Torres EM, Mahal A, Mangiarini L, Bates G, Morton AJ (1998) Striatal transplantation in a transgenic mouse model of Huntington's disease. Exp Neurol 154(1):31-40

333. Deckel AW, Volmer P, Weiner R, Gary KA, Covault J, Sasso D, Schmerler N, Watts D, Yan Z, Abeles I (2000) Dietary arginine alters time of symptom onset in Huntington's disease transgenic mice. Brain Res 875(1-2):187-195

334. Deckel AW, Tang V, Nuttal D, Gary K, Elder R (2002) Altered neuronal nitric oxide synthase expression contributes to disease progression in Huntington's disease transgenic mice. Brain Res 939(1-2):76-86

335. van Dellen A, Deacon R, York D, Blakemore C, Hannan AJ (2001) Anterior cingulate cortical transplantation in transgenic Huntington's disease mice. Brain Res Bull 56(3-4):313-318

336. Clifford JJ, Drago J, Natoli AL, Wong JYF, Kinsella A, Waddington JL, Vaddadi KS (2002) Essential fatty acids given from conception prevent topographies of motor deficit in a transgenic model of Huntington's disease. Neuroscience 109(1):81-88

337. Schiefer J, Landwehrmeyer GB, Lüesse H-G, Sprünken A, Puls C, Milkereit A, Milkereit E, Kosinski CM (2002) Riluzole prolongs survival time and alters nuclear inclusion formation in a transgenic mouse model of Huntington's disease. Mov Disord 17(4):748-757

338. Gil JMAC, Leist M, Popovic N, Brundin P, Petersén A (2004) Asialoerythropoietin is not effective in the R6/2 line of Huntington's disease mice. BMC Neurosci 5:17

339. Zucker B, Ludin DE, Gerds TA, Lücking $\mathrm{CH}$, Landwehrmeyer GB, Feuerstein TJ (2004) Gabapentin-lactam, but not gabapentin, reduces protein aggregates and improves motor performance in a transgenic mouse model of Huntington's disease. Naunyn Schmiedebergs Arch Pharmacol 370(2):131-139

340. Morton AJ, Hunt MJ, Hodges AK, Lewis PD, Redfern AJ, Dunnett SB, Jones L (2005) A combination drug therapy improves cognition and reverses gene expression changes in a mouse model of Huntington's disease. Eur J Neurosci 21(4):855-870

341. Nguyen T, Hamby A, Massa SM (2005) Clioquinol downregulates mutant huntingtin expression in vitro and mitigates pathology in a Huntington's disease mouse model. Proc Natl Acad Sci U S A 102(33):11840-11845

342. Van Raamsdonk JM, Pearson J, Rogers DA, Lu G, Barakauskas VE, Barr AM, Honer WG, Hayden MR, Leavitt BR (2005) EthylEPA treatment improves motor dysfunction, but not neurodegeneration in the YAC128 mouse model of Huntington disease. Exp Neurol 196(2):266-272

343. Bailey CDC, Johnson GVW (2006) The protective effects of cystamine in the R6/2 Huntington's disease mouse involve mechanisms other than the inhibition of tissue transglutaminase. Neurobiol Aging 27(6):871-879

344. Bett JS, Goellner GM, Woodman B, Pratt G, Rechsteiner M, Bates GP (2006) Proteasome impairment does not contribute to pathogenesis in R6/2 Huntington's disease mice: exclusion of 
proteasome activator REGgamma as a therapeutic target. Hum Mol Genet 15(1):33-44

345. Qiu Z, Norflus F, Singh B et al (2006) Sp1 is up-regulated in cellular and transgenic models of Huntington disease, and its reduction is neuroprotective. $\mathrm{J}$ Biol Chem 281(24):16672-16680

346. Dey ND, Boersen AJ, Myers RA, York LR, Bombard MC, Lu M, Sandstrom MI, Hulce VD, Lescaudron L, Dunbar GL (2007) The novel substituted pyrimidine, KP544, reduces motor deficits in the R6/2 transgenic mouse model of Huntington's disease. Restor Neurol Neurosci 25(5-6):485-492

347. Glynn D, Reim K, Brose N, Morton AJ (2007) Depletion of Complexin II does not affect disease progression in a mouse model of Huntington's disease (HD); support for role for complexin II in behavioural pathology in a mouse model of HD. Brain Res Bull 72(2-3):108-120

348. Merienne K, Friedman J, Akimoto M, Abou-Sleymane G, Weber C, Swaroop A, Trottier Y (2007) Preventing polyglutamineinduced activation of c-Jun delays neuronal dysfunction in a mouse model of SCA7 retinopathy. Neurobiol Dis 25(3):571-581

349. Stack EC, Dedeoglu A, Smith KM et al (2007) Neuroprotective effects of synaptic modulation in Huntington's disease R6/2 mice. J Neurosci 27(47):12908-12915

350. Yang Z, Chang Y-J, Yu I-C et al (2007) ASC-J9 ameliorates spinal and bulbar muscular atrophy phenotype via degradation of androgen receptor. Nat Med 13(3):348-353

351. Zourlidou A, Gidalevitz T, Kristiansen M et al (2007) Hsp27 overexpression in the R6/2 mouse model of Huntington's disease: chronic neurodegeneration does not induce Hsp27 activation. Hum Mol Genet 16(9):1078-1090

352. Cipriani S, Bizzoco E, Gianfriddo M, Melani A, Vannucchi MG, Pedata F (2008) Adenosine A2A receptor antagonism increases nNOS-immunoreactive neurons in the striatum of Huntington transgenic mice. Exp Neurol 213(1):163-170

353. Chen X, Tang T-S, Tu H, Nelson O, Pook M, Hammer R, Nukina N, Bezprozvanny I (2008) Deranged calcium signaling and neurodegeneration in spinocerebellar ataxia type 3. J Neurosci 28 (48):12713-12724

354. Chintawar S, Hourez R, Ravella A, Gall D, Orduz D, Rai M, Bishop DP, Geuna S, Schiffmann SN, Pandolfo M (2009) Grafting neural precursor cells promotes functional recovery in an SCA1 mouse model. J Neurosci 29(42):13126-13135

355. Dai Y, Dudek NL, Li Q, Fowler SC, Muma NA (2009) Striatal expression of a calmodulin fragment improved motor function, weight loss, and neuropathology in the R6/2 mouse model of Huntington's disease. J Neurosci 29(37):11550-11559

356. Benn CL, Butler R, Mariner L, Nixon J, Moffitt H, Mielcarek M, Woodman B, Bates GP (2009) Genetic knock-down of HDAC7 does not ameliorate disease pathogenesis in the R6/2 mouse model of Huntington's disease. PLoS One 4(6):e5747

357. Lee S-T, Chu K, Jung K-H et al (2009) Slowed progression in models of Huntington disease by adipose stem cell transplantation. Ann Neurol 66(5):671-681

358. Li M, Huang Y, Ma AAK, Lin E, Diamond MI (2009) Y-27632 improves rotarod performance and reduces huntingtin levels in R6/2 mice. Neurobiol Dis 36(3):413-420

359. Liu J, Tang T-S, Tu H, Nelson O, Herndon E, Huynh DP, Pulst SM, Bezprozvanny I (2009) Deranged calcium signaling and neurodegeneration in spinocerebellar ataxia type 2. J Neurosci 29(29):9148-9162

360. Palazzolo I, Stack C, Kong L et al (2009) Overexpression of IGF1 in muscle attenuates disease in a mouse model of spinal and bulbar muscular atrophy. Neuron 63(3):316-328

361. Pouladi MA, Graham RK, Karasinska JM, Xie Y, Santos RD, Petersén A, Hayden MR (2009) Prevention of depressive behaviour in the YAC128 mouse model of Huntington disease by mutation at residue 586 of huntingtin. Brain 132 (Pt 4):919-932

362. Tallaksen-Greene SJ, Janiszewska A, Benton K, Hou G, Dick R, Brewer GJ, Albin RL (2009) Evaluation of tetrathiomolybdate in the R6/2 model of Huntington disease. Neurosci Lett 452(1):60-62

363. Tang T-S, Guo C, Wang H, Chen X, Bezprozvanny I (2009) Neuroprotective effects of inositol 1,4,5-trisphosphate receptor C-terminal fragment in a Huntington's disease mouse model. J Neurosci 29(5):1257-1266

364. Vamos E, Voros K, Zadori D, Vecsei L, Klivenyi P (2009) Neuroprotective effects of probenecid in a transgenic animal model of Huntington's disease. J Neural Transm 116(9):1079-1086

365. Bauer PO, Goswami A, Wong HK et al (2010) Harnessing chaperone-mediated autophagy for the selective degradation of mutant huntingtin protein. Nat Biotechnol 28(3):256-263

366. Decressac M, Wright B, Tyers P, Gaillard A, Barker RA (2010) Neuropeptide Y modifies the disease course in the R6/2 transgenic model of Huntington's disease. Exp Neurol 226(1):24-32

367. Snyder BR, Chiu AM, Prockop DJ, Chan AWS (2010) Human multipotent stromal cells (MSCs) increase neurogenesis and decrease atrophy of the striatum in a transgenic mouse model for Huntington's disease. PLoS One 5(2):e9347

368. Chen X, Wu J, Lvovskaya S, Herndon E, Supnet C, Bezprozvanny I (2011) Dantrolene is neuroprotective in Huntington's disease transgenic mouse model. Mol Neurodegener 6:81

369. Duarte AI, Petit GH, Ranganathan S, Li J-Y, Oliveira CR, Brundin P, Björkqvist M, Rego AC (2011) IGF-1 protects against diabetic features in an in vivo model of Huntington's disease. Exp Neurol 231(2):314-319

370. Hourez R, Servais L, Orduz D, Gall D, Millard I, de Kerchove d'Exaerde A, Cheron G, Orr HT, Pandolfo M, Schiffmann SN (2011) Aminopyridines correct early dysfunction and delay neurodegeneration in a mouse model of spinocerebellar ataxia type 1. J Neurosci 31(33):11795-11807

371. Jafar-Nejad P, Ward CS, Richman R, Orr HT, Zoghbi HY (2011) Regional rescue of spinocerebellar ataxia type 1 phenotypes by 14-3-3epsilon haploinsufficiency in mice underscores complex pathogenicity in neurodegeneration. Proc Natl Acad Sci U S A 108(5):2142-2147

372. Lim S, Chesser AS, Grima JC, Rappold PM, Blum D, Przedborski $\mathrm{S}$, Tieu K (2011) D- $\beta$-hydroxybutyrate is protective in mouse models of Huntington's disease. PLoS One 6(9):e24620

373. Lin Y-S, Chen C-M, Soong B et al (2011) Dysregulated brain creatine kinase is associated with hearing impairment in mouse models of Huntington disease. J Clin Invest 121(4):1519-1523

374. Lin Y-T, Chern Y, Shen C-KJ, Wen H-L, Chang Y-C, Li H, Cheng T-H, Hsieh-Li HM (2011) Human mesenchymal stem cells prolong survival and ameliorate motor deficit through trophic support in Huntington's disease mouse models. PLoS One 6(8):e22924

375. Maher P, Dargusch R, Bodai L, Gerard PE, Purcell JM, Marsh JL (2011) ERK activation by the polyphenols fisetin and resveratrol provides neuroprotection in multiple models of Huntington's disease. Hum Mol Genet 20(2):261-270

376. Mughal MR, Baharani A, Chigurupati S, Son TG, Chen E, Yang P, Okun E, Arumugam T, Chan SL, Mattson MP (2011) Electroconvulsive shock ameliorates disease processes and extends survival in huntingtin mutant mice. Hum Mol Genet 20(4):659-669

377. Bobrowska A, Paganetti P, Matthias P, Bates GP (2011) Hdac6 knock-out increases tubulin acetylation but does not modify disease progression in the R6/2 mouse model of Huntington's disease. PLoS One 6(6):e20696

378. Sadagurski M, Cheng Z, Rozzo A, Palazzolo I, Kelley GR, Dong X, Krainc D, White MF (2011) IRS2 increases mitochondrial dysfunction and oxidative stress in a mouse model of Huntington disease. J Clin Invest 121(10):4070-4081 
379. Chang Y-K, Chen M-H, Chiang Y-H, Chen Y-F, Ma W-H, Tseng C-Y, Soong B-W, Ho JH, Lee OK (2011) Mesenchymal stem cell transplantation ameliorates motor function deterioration of spinocerebellar ataxia by rescuing cerebellar Purkinje cells. J Biomed Sci 18:54

380. Vig PJS, Hearst S, Shao Q, Lopez ME, Murphy HA 2nd, Safaya E (2011) Glial S100B protein modulates mutant Ataxin-1 aggregation and toxicity: TRTK12 peptide, a potential candidate for SCA1 therapy. Cerebellum 10(2):254-266

381. Wang X, Sirianni A, Pei Z et al (2011) The melatonin MT1 receptor axis modulates mutant Huntingtin-mediated toxicity. J Neurosci 31(41):14496-14507

382. Zhu S, Zhang Y, Bai G, Li H (2011) Necrostatin-1 ameliorates symptoms in R6/2 transgenic mouse model of Huntington's disease. Cell Death Dis 2:e115

383. Chang Y-C, Lin C-Y, Hsu C-M, Lin H-C, Chen Y-H, Lee-Chen G-J, Su M-T, Ro L-S, Chen C-M, Hsieh-Li HM (2011) Neuroprotective effects of granulocyte-colony stimulating factor in a novel transgenic mouse model of SCA17. J Neurochem 118 (2):288-303

384. Chen KA, Cruz PE, Lanuto DJ, Flotte TR, Borchelt DR, Srivastava A, Zhang J, Steindler DA, Zheng T (2011) Cellular fusion for gene delivery to SCA1 affected Purkinje neurons. Mol Cell Neurosci 47(1):61-70

385. Chen X, Wu J, Luo Y et al (2011) Expanded polyglutaminebinding peptoid as a novel therapeutic agent for treatment of Huntington's disease. Chem Biol 18(9):1113-1125

386. Di Pardo A, Maglione V, Alpaugh M et al (2012) Ganglioside GM1 induces phosphorylation of mutant huntingtin and restores normal motor behavior in Huntington disease mice. Proc Natl Acad Sci U S A 109(9):3528-3533

387. Kwan W, Magnusson A, Chou A et al (2012) Bone marrow transplantation confers modest benefits in mouse models of Huntington's disease. J Neurosci 32(1):133-142

388. Moumné L, Campbell K, Howland D, Ouyang Y, Bates GP (2012) Genetic knock-down of HDAC3 does not modify disease-related phenotypes in a mouse model of Huntington's disease. PLoS One 7(2):e31080

389. Noma S, Ohya-Shimada W, Kanai M, Ueda K, Nakamura T, Funakoshi H (2012) Overexpression of HGF attenuates the degeneration of Purkinje cells and Bergmann glia in a knockin mouse model of spinocerebellar ataxia type 7. Neurosci Res 73(2):115-21

390. Kordasiewicz HB, Stanek LM, Wancewicz EV et al (2012) Sustained therapeutic reversal of Huntington's disease by transient repression of Huntingtin synthesis. Neuron 74(6):1031-1044

391. Pouladi MA, Brillaud E, Xie Y et al (2012) NP03, a novel lowdose lithium formulation, is neuroprotective in the YAC128 mouse model of Huntington disease. Neurobiol Dis. doi:10.1016/ j.nbd.2012.06.026

392. Helmlinger D, Bonnet J, Mandel J-L, Trottier Y, Devys D (2004) Hsp70 and Hsp40 chaperones do not modulate retinal phenotype in SCA7 mice. J Biol Chem 279(53):55969-55977

393. Labbadia J, Novoselov SS, Bett JS, Weiss A, Paganetti P, Bates GP, Cheetham ME (2012) Suppression of protein aggregation by chaperone modification of high molecular weight complexes. Brain: A Journal of Neurology 135(Pt 4):1180-96

394. Ebert AD, Barber AE, Heins BM, Svendsen CN (2010) Ex vivo delivery of GDNF maintains motor function and prevents neuronal loss in a transgenic mouse model of Huntington's disease. Exp Neurol 224(1):155-162

395. Popovic N, Maingay M, Kirik D, Brundin P (2005) Lentiviral gene delivery of GDNF into the striatum of R6/2 Huntington mice fails to attenuate behavioral and neuropathological changes. Exp Neurol 193(1):65-74

396. Cvetanovic M, Patel JM, Marti HH, Kini AR, Opal P (2011) Vascular endothelial growth factor ameliorates the ataxic phenotype in a mouse model of spinocerebellar ataxia type 1. Nat Med 17(11):1445-1447

397. Mielcarek M, Benn CL, Franklin SA, Smith DL, Woodman B, Marks PA, Bates GP (2011) SAHA decreases HDAC 2 and 4 levels in vivo and improves molecular phenotypes in the R6/2 mouse model of Huntington's disease. PLoS One 6(11):e27746 